\title{
EFEITO DE REGIÕES E ÉPOCAS DE PRODUÇÃO NA QUALIDADE DE SEMENTES DE FEIJOEIRO (Phaseolus oulgaris L.) NO ESTADO DE SÃO PAULO
}

\author{
SILVÂNIA HELENA FURLAN \\ Engenheira Agrônoma
}

Orientador: Prof. Dr. JOSÉ O. M. MENTEN

Dissertação apresentada à Escola Superior de Agricultura "Luiz de Queiroz", da Universidade de São Paulo, para obtenção do título de Mestre em Agronomia. Área de concentração: Fitopatologia.

PIRACICABA

Estado de São Paulo - Brasil

Novembro - 1986 
Aos meus pais Fiorige e Cleufe,

meus irmãos Sérgio, Sandra, Fätima

Cësar e Fernanda.

OFEREÇO

Aos amigos,

com carinho,

DEDICO 


\section{AGRADECIMENTOS}

A autora expressa seus agradecimentos:

- Ao Departamento de Fitopatologia da Escola Superior de Agricultura "Luiz de Queiroz", professores e funcionārios.

- Ao Prof. Dr. José Otavio Machado Menten, pela amizade, orientação e incentivos constantes, durante toda a realização deste trabalho.

- Ao Prof. Dr. Hiroshi Kimati, alëm do agradecimento pelas atenções dispensadas, expresso minha estima e admiração.

- A todos colegas do curso de pós-graduação especial mente a Maria Heloisa D. Morais e Heloisa Morato pela amizade e carinho e a Jorge Bleischer pelos valiosos ensinamentos em Estatística.

- A Fundação de Pesquisa do Estado de São Paulo (FAPESP), pela concessão de bolsa de estudo.

- A Coordenadoria de Assistēncia Técnica e Integral (CATI), pelo fornecimento das sementes.

- Ao Laboratório de Sementes do Departamento de Agri cultura e Horticultura da ESALQ, pela concessão à realização dos testes de germinação e vigor das sementes. 


\section{INDICE}

página

RESUMO

viii

SUMMARY

$\mathrm{xi}$

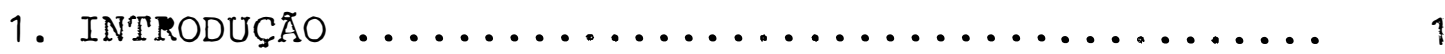

2. REVISÃO DE LITERATURA ................... 4

2.1. Importância da sanidade de sementes ........ 4

2.2. Doenças do feijoeiro causadas por microrganis mos associados às sementes .............. 7

2.2.1. Doenças füngicas .............. 8

2.2.2. Doenças bacterianas .............. 14

2.2.3. Doenças viróticas ................. 17

2.2.4. Fungos de armazenamento ........... 19

2.3. Linhas de pesquisa da patologia de sementes

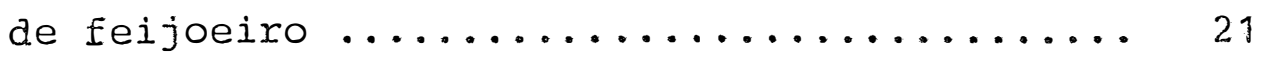

2.3.1. Levantamento da sanidade de sementes e efeito do local de produção ........ 21

2.3.2. Metodologia da deteção de fungos .... 25

2.3.3. Avaliação de danos causados por fungos associados às sementes ............. 29

2.3.4. Epidemiologia e estabelecimento de niveis de tolerância de patógenos associados às sementes ................ 32

2.3.5. Controle das doenças ........... 36

3. MATERIAL E METOdOS ........................ 42

3.1. Caracterização das amostras de sementes anali sadas 
página

3.2. Análise da sanidade das sementes ........ 55

3.3. Análise fisiolǵoica das sementes ........ 56

3.4. Precipitação das regiões produtoras de semen tes de feijoeiro no Estado de são Paulo .... 57

3.5. Delineamento experimental ............. 57

4. RESUltados ........................... 64

4.1. Fungos detectados nas sementes de feijoeiro pelos métodos de papel de filtro comum e papel de filtro com congelamento .......... 64

4.1.1. Incidência de Alternaria spp. ...... 65

4.1.2. Incidência de Alternaria tenuis .... 70

4.1.3. Incidência de Aspergillus ......... 70

4.1.4. Incidência de Cladosporium ........ 70

4.1.5. Incidência de Fusarium ........... 71

4.1.6. Incidência de Fusarium equiseti .... 71

4.1.7. Incidência de Fusarium moniliforme .. 71

4.1.8. Incidência de Fusarium oxysporum .... 72

4.1.9. Incidência de Fusarium semitectum ... 72

4.1.10. Incidência de Penicillium ........ 73

4.1.11. Incidência de Phomopsis ......... 73

4.1.12. Incidência de Rhizoctonia solani ... 73

4.1.13. Incidência de Botryodiplodia theobromae 74

4.1.14. Incidência de Colletotrichum lindemuthianum ..................... 74

4.1.15. Incidência de Macrophomina phaseolina 74 
página

4.2. Correlação entre métodos de deteç̧ão ....... 7 9

4.3. Teste de interações .................. 75

4.4. Incidência de fungos, germinação e envelhecimento acelerado das sementes das cultivares

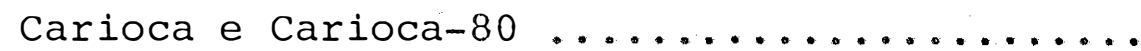

4.5. Efeito de regiōes na incidência de fungos associados às sementes, dentro de cada época de produção $\ldots \ldots \ldots \ldots \ldots \ldots \ldots \ldots \ldots \ldots \ldots \ldots \ldots \ldots \ldots \ldots \ldots \ldots \ldots \ldots \ldots$

4.6. Efeito de regiōes e de épocas na germinação e envelhecimento acelerado das sementes ...... 91

4.7. Correlação entre sanidade, germinação e enveThecimento acelerado das sementes ......... 95

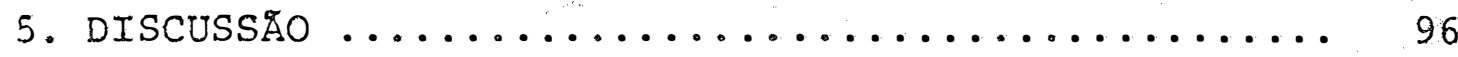

5.1. Fungos associados às sementes de feijoeiro... 96

5.2. Avaliação dos métodos de deteçãa de fungos . 98

5.3. Correlação entre métodos de deteção de fungos. 101

5.4. Distribuição geogräfica dos fungos ........ 102

5.5. Efeito do genótipo na incidência de fungos, germinação e envelhecimento acelerado das se-

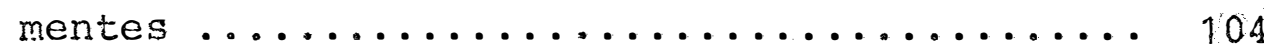

5.6. Seleção de regiōes e épocas de produção de se mentes de feijoeiro no Estado de São Paulo .. 105

5.7. Efeito da sanidade na germinação e envelhecimento acelerado das sementes ............ 110 
-vii.

página

5.8. Correlação entre germinação e vigor das sementes de feijoeiro .................... 112

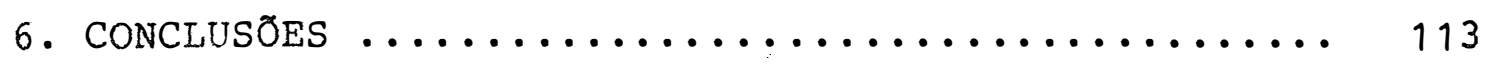

7. REFERENCIAS BIBLIOGRAFICAS ................. 115 
EFEITO DE REGIÕES E ÉPOCAS DE PRODUÇÃO NA QUALIDADE DE SEMENTES DE FEIJOEIRO (Phaseolus vulgaris L.) NO ESTADO DE SÃO PAULO

\author{
Autora: SILVANIA HELENA FURLAN \\ Orientador: Prof. Dr. JOSE O.M. MENTEN
}

RESURO

Avaliaram-se 133 amostras de sementes de feijoeiro procedentes de várias regiões do Estado de São Paulo, produzidas nas épocas da seca de 1984, das águas de 1984/85, e de inverno de 1985, com o objetivo de selecionar regiões e épocas de produção de sementes de melhor qualidade.

A avaliação da qualidade das sementes foi determinada através da sanidade, germinação e envelhecimento precoce. Os testes de sanidade utilizados foram o método de papel de filtro comum e o método de papel de filtro com congelamento,

Uma ampla microflora füngica encontrou-se associada às sementes de feijoeiro. Entre os fungos detectados, constataram-se: Alternaria spp., Alternaria tenuis, Col letotrichum lindemuthianum, Fusarium equiseti, F. moniliforme, F. oxysporum, F. semitectum, Macrophomina phaseolina, Ph. 
mopsis sp. e Rhizoctonia solani.

Os resultados de sanidade das sementes mostra ram, que o método de papel de filtro com congelamento, para deteç̧ão de fungos, foi melhor que o papel de filtro comum, pela maior recuperação e facilidade de avaliação.

Das cultivares estudadas, Carioca e Carioca-80 , esta última apresentou sementes de melhor qualidade, da da à menor frequência da maioria dos fungos associados e à maior capacidade de germinação e vigor (envelhecimento acele rado) .

De maneira geral, a sanidade das sementes de feijoeiro foi boa, considerando a baixa frequência de fungos economicamente importantes à cultura, havendo, no entanto, efeito de regiões dentro de cada época de produção. Houve, também, o efeito de regiões e épocas de produção na germinação e envelhecimento acelerado das sementes.

As sementes de feijoeiro produzidas na êpoca de inverno apresentaram maior capacidade de germinação $(78,0 \%)$ e vigor $(68,0 \%)$ em relação à época da seca e das águas, que apresentaram valores de 77,5\% e 68,0\% para germinação, e $61,0 \%$ e $50,0 \%$ para vigor, respectivamente.

Pelos parâmetros avaliados, as melhores áreas para produção de sementes corresponderam ao cultivo de inver 
no: Bauru, Ibitinga, Jaboticabal e Presidente Prudente, seguidas por Aguaí, Fernandópolis, Pirassununga e Ribeirão Pre to, que apresentaram germinação ou vigor inferiores às primeiras. Sementes de boa qualidade também foram produzidas na safra da seca, particularmente nas regiões de Bauru, Jaboticabal, Araçatuba, Itapetininga e Tatuí.

O importante agente fúngico associado às sementes de feijoeiro, colletotrichum lindemuthianum, ocorreu em baixa incidência $(0,5$ a $1,0 \%)$ em 4,5 das amostras, das quais metade foi produzida na ëpoca da seca e as demais na êpoca das águas, procedentes das regiões Avaré e Itapetininga. Sementes produzidas no inverno não apresentaram infecção pelo patógeno. 
INFLUENCE OF THE PRODUCTION REGIONS AND THE GROWING SEASONS ON THE QUALITY OF BEAN SEEDS (Phaseolus vulgaris L.) IN THE STATE OF SÃO PAULO, BRAZIL

Author: SILVÃNIA HELENA FURLAN

Adviser: Prof. Dr. JOSE O.M. MENTEN

\section{SUMMARY}

One hundred and thirty three samples of bean seeds, from various regions of the state of são Paulo, produced in field of dry season crop of 1984, rainy season of $1984 / 85$ and winter season of 1985, were analysed in order to select regions and season for production of seeds of higher quality.

The quality of bean seeds was evaluated by health tests, germination test and accelerated aging test. Seed health tests were performed by the blotter test and the freezing method.

A large number of genera and species of fungi were observed, among them Alternaria spp., Alternaria tenuis, Colletotrichum lindemuthianum, Fusarium equiseti, F. moniliforme, F. oxysporum, F. semitectum, Macrophomina phaseolina, 
Phomopsis sp. and Rhizoctonia solani.

The freezing method was better than the blotter test, enabling a greater recovery of seed-borne fungi and was easier to apply.

It was observed that the seeds of bean $\mathrm{cv}$. "Carioca-80" were healthier then the other cv. "Carioca" used, presenting a smaller quantity of fungi, and having greater germination and vigor (accelerated aging test).

In the general the seed health of bean was good, with a low prevalence of fungi economically important to bean crops; there was, however, an influence of regions and seasons of production on the seed health. The germination and the vigor of the seeds were also influenced by regions and seasons.

Bean seeds produced during the winter had a higher germination capacity (78.0\%) and vigor (68.0\%) than those of dry season and rainy season bean crops, which had, $77.5 \%$ and $68.0 \%$ germination capacity, and $61.0 \%$ and $50.0 \%$ vigor, respectively.

The production of better quality seeds corresponded to the winter crop in the regions of Bauru, Ibitinga, Jaboticabal and Presidente Prudente which were Followed by Aguai, Fernandópolis, Pirassununga and Ribeirão Preto. Seeds of good quality were also produced on the dry 
high quality were also produced in the dry season, particularly in the regions of Bauru, Jaboticabal, Araçatuba, Itapetininga and Tatui.

Colletotrichum lindemuthianum occurred at low frequencies $(0.5$ to $1.0 \%$ ), in $4.5 \%$ of the samples from Avare and Itapetininga, half from dry season bean crops and half from rainy season bean crops. Seeds produced on the winter season bean didn't had infection by the pathogen. 


\section{INTRODUÇÃO}

A utilização de sementes melhoradas representa um dos fatores primordiais de produtividade para $\circ$ feijoeiro, cultura de alto risco e de elevada importância em nosso pais.

A produção de sementes melhoradas de feijoeiro, na safra 84/85, foi de 11750 t em São Paulo, 5050 t no Paraná e 3200 t em Minas Gerais, principais Estados produtores. A previsão inicial para $85 / 86$ em todo país é de 35000 $t$ (ABRASEM, 1986), o que indica uma preocupação constante de se fornecer aos produtores 0 insumo de alta qualidade. Por outro lado, sabe-se que a taxa de utilização de sementes cer tificadas e fiscalizadas no Estado de São Paulo vem decrescendo, com valores de 14,5\% em 1981 e 12,3\% em 1983 (PROGNOS TICO, 1984).

Além dos aspectos fisiológicos, a sanidade de 
sementes de feijoeiro representa um ponto bastante significa tivo na produção, pois muitos são os patógenos a elas associados. Entre os mais importantes, estão o agente da antrac nose, Colletotrichum lindemuthianum, da bacteriose, Xanthomo nas campestris pv. phaseoli, e o virus do mosaico comum do feijoeiro. Segundo NEERGAARD (1979a), a flora fúngica das sementes pode variar de acordo com as condições climáticas.

Alguns trabalhos têm fornecido informações va liosas sobre a sanidade das sementes de feijoeiro de determi nadas regiões produtoras, subsidios importantes para a seleção de áreas propícias à produção. (LASCA, 1978; MELO, 1980; ITO et alii, 1981; MENEZES, 1981 ; OLIVEIRA, 1984; SANTOS, 1986). Todavia, maior número de conhecimentos são imprescin díveis para obtenção do controle de doenças causadas por patógenos transmitidos pelas sementes.

VIEIRA (1981) ressalta a necessidade de estudos visando determinar melhores áreas à produção de feijão, definindo zonas de clima favorável à produção de sementes pu ras, com grau de sanidade elevado, pois as regiões apresentam grande diversidade de clima e solo.

O presente trabalho teve como objetivo principal determinar o efeito de épocas e regiões de produção na qualidade de sementes de feijoeiro produzidas no Estado de São Paulo, além do efeito do genōtipo, tendo como parâmetros 
a sanidade, a germinação e o envelhecimento acelerado. Foram verificadas, também, as correlações entre esses parâmetros indicadores da qualidade das sementes, com ênfase no efeito de fungos na germinação e vigor; compararam-se os métodos de papel de filtro comum e papel de filtro com congelamento, e determinou-se a correlação entre eles. 


\section{REVISÃO DE LITERATURA}

\subsection{IMPORTÂNCIA DA SANIDADE DE SEMENTES}

As sementes constituem o insumo fundamental para a agricultura, atravēs das quais, a maioria das especies de plantas expressam seu potencial genético, e permitem a sua perpetuação e disseminação.

Para CARVALHO \& NAKAGAWA (1983), os fatores que afetam a produção e o desempenho das sementes abrangem sua origem, vigor, teor de umidade, injūrias mecânicas, sani dade, tamanho das sementes, época e densidade de semeadura,e adubação .

Toda a metodologia aplicada para o uso correto das terras, objetivando a maior produtividade, está intimamente dependente da utilizaģão de uma semente de comprova da pureza física, genética e sanitária (AZEVEDO \& LAUDARES 
Filho, 1982).

Apesar da elevada importāncia da utilização de sementes melhoradas gerando maior produtividade, a taxa de adoção pelos agricultores de sementes de boa qualidade é muito pequena (PROGNOSTICO, 1984).

$\mathrm{Na}$ instalação dos campos de produção de semen tes recomenda-se cuidados especiais quanto à origem do material a ser multiplicado e aos locais, os quais não devem ser propícios ao aparecimento de doenças, uma vez que elas podem comprometer seriamente a cultura, inclusive suas sementes (TOLEDO \& MARCOS Filho, 1977 e SILVA, 1978). Além das perdas de produtividade decorrentes das doenças no campo, poden do afetar o "stand", o sistema radicular e a parte aérea das plantas, poderá haver contaminação ou infecção das sementes pelos patógenos durante o seu cultivo (NEERGAARD, 1979a).

NEERGAARD (1979a) e DHINGRA et alii (1980) levan taram o fato de que a epidemia de mitas doenças pode ter inicio com inóculos contidos nas sementes, além de serem estas um dos vei culos mais importantes de transmissão dos patógenos. A disse minação desses patógenos é bastante eficiente, pois estes estão em íntima associação com o hospedeiro, além do livre e fácil comércio interno de sementes. Esse problema torna-se mais agravante na cultura do feijoeiro, pelo fato da maioria das principais doenças terem seus patógenos transmitidos a- 
través das sementes (ELLIS \& GÃLVEZ, 1980).

A ação do serviço de quarentena, na comercialização internacional, procura impedir a entrada de sementes associadas com microrganismos indesejāveis, ao passo que, no comércio interno, somente a germinação e a pureza física do lote são parãmetros para avaliação da qualidade de sementes no Brasil, com raras exceções, como no caso de Cercospora kí kuchi em sementes de soja (LUCCA Filho, 1984). Deve-se chamar atenção de que, mesmo nesse caso, apenas o exame visual baseado nos sintomas das sementes é, até o momento, considerado; sabe-se, porém, que nem sempre os sintomas representam a presença ou não do patógeno.

Muitos fungos são sérios parasitas de primórdios de sementes e sementes maduras, e reduzem a produtivida de, quantitativa e qualitativamente. Outros, incluindo saprófitas e parasitas fracos, podem reduzir a qualidade das mesmas devido à descoloração, o que pode depreciar o valor comercial das sementes, particularmente dos grãos. Os tipos de sintomas encontrados, geralmente em combinação, podem ser o aborto da semente, a esclerotização ou estromatização, a redução do tamanho, a podridão, a necrose, as manchas das sementes, a redução ou eliminação da capacidade de germina ção e as alterações fisiológicas na semente (NEERGAARD， 1979a) 
O mesmo autor cita exemplos de alteração na cor de sementes causada por fungos, indicando baixa qualidade das mesmas. Entre eles estão Colletotrichum lindemuthia num e Isariopsis griseola em feijão, Drechslera oryzae em ax roz, Fusarium equiseti, F. semitectum e Macrophomina phaseolina em feijão-mungo (Phaseolus aureus), F. monilikorme e Ce phalosporim acremonium em milho (riscas brancas, frequentemente a partir do embrião). A alteração na cor do tegumento da semente pode ser, ainda, devido a lesões produzidas por bactérias fitopatogênicas, Xanthomonas campestrispv. phaseo$l i, x . c a m p e s t r i s$ pv. phaseoli var. fuscans, em cultivares de feijoeiro de sementes brancas, onde podem ser visiveis algumas manchas amareladas.

\subsection{DOENÇAS DO FEIJOEIRO CAUSADAS POR MICRORGANISMOS AS- SOCIADOS ÀS SEMENTES}

Mais da metade das principais doenças do feijoeiro têm seus agentes associados às sementes, incluindo fun gos, bactérias e vírus. ATHAIDE \& PACOVA (1985) têm constatado, no Espirito Santo, a transmissão em sementes de feijoiro de Colletotrichum lindemuthianum, Xanthomonas campestris pv. phaseoli, vírus do mosaico comum, e outros. Tais patógenos podem ser considerados limitantes à produção em determinadas regiões, recomendando todo cuidado a fim de se evitar a pre- 
sença deles no campo de produção de sementes.

\section{$2,2,1$. DOENGAS FÚNGICAS}

\section{a. Antracnose - Colletotrichum lindemuthianum}

Apresenta-se como uma das doenças mais importantes da cultura, podendo causar danos severos quanco ; as condições climáticas forem favoráveis. Sua distribuição é generalizada nas diversas áreas produtoras de feijão no Bra sil e no mundo inteiro (KIMATI, 1980; SCHWARTZ \& GALVEZ, 1980; VIEIRA, 1983). A grande importância para a cultura pro vêm, principalmente, da presença do patógeno nas sementes , meio mais eficiente de disseminação e transmissão. Nos Esta dos Unidos, os danos ocorridos pela doença no início do sécu 10 eram de 30 a $100 \%$, enquanto hoje, são de apenas $0,5 \%$, devido à produção de sementes certificadas nas áreas semi-áridas (NEERGAARD, 1979a).

O agente causal da antracnose, Colletotrichum lindemuthianum, localiza-se como micélio tanto no tegumento como no embrião da semente (ANSELME \& CHAMPION, 1981). As condições ótimas para o seu desenvolvimento são alta umidade e temperatura entre 18 e $22^{\circ} \mathrm{C}$ (ZAMBOLIM \& CHAVES, 1978).

A doença provoca o aparecimento de lesões nas sementes, nas hastes e nas folhas; todavia, nas vagens, os 
sintomas são mais caracteristicos. As sementes atacadas apresentam lesões deprimidas, de tamanhos variáveis, de cor entre parda e negra, dependendo da cor do tegumento atacado; - patógeno pode atravessar o tegumento e atingir os cotilédo nes. No hipocótilo das plântulas podem surgir lesões escuras, resultantes, geralmente, de esporos de cotilédones infectados, trazidos para baixo pela água das chuvas. Nas folhas, a infecção ocorre no pecíolo e nas nervuras, na face inferior, adquirindo coloração escura. Nas vagens, a antrac nose apresenta-se sob a forma de lesões escuras, arredondadas, deprimidas e de tamanho variável, podendo, então, atingir as sementes. Quando as condições de umidade e temperatu ra são favoráveis, forma-se umá massa de esporos, de coloração rosada, no centro das lesões (COSTA, 1972; KIMATI, 1980; VIEIRA, 1983) .

b. Mancha angular - Isariopsis griseola

No Brasil, a doença é generalizada, todavia não causa danos apreciáveis, ocorrendo geralmente em final de ciclo. No entanto, pelo que já se tem observado, vem adquirindo importância nos últimos anos, pela suscetibilidade manifestada nas cultivares utilizadas, como Carioca e Carioca-80, favorecida pelas condições ambientes favoráveis. Em paỉses como México e Colômbia têm-se registrado perdas máximas de colheita entre 60 e $80 \%$ (VIEIRA, 1983) e $50 \%$ nos Esta dos Unidos (HAGEDORN \& WADE, 1974). 
O agente causal da mancha angular, Isariopsis grisela, ataca Phaseolus vulgaris, P. Lunatus e Vigna unguiculata, desenvolvendo-se bem em temperaturas entre 16 e $18^{\circ} \mathrm{C}$, e alta umidade relativa. O sintoma mais típico é o aparecimento de lesões de formato angular, delimitadas pelas nervuras na face inferior das folhas, a princípio de coloração cinzenta, tornando-se castanhas mais tarde, Quando muito numerosas, podem provocar a queda prematura das folhas. Nas va gens, as manchas são pardo-avermelhadas, com bordas escuras, quase circulares e de tamanhos variáveis (ZAMBOIIN \& CHAVES, 1978) .

C. Podridão cinzenta do caule - Macrophomina phaseolina

Esta doença, de modo geral, é considerada de menor importância na maioria das áreas onde se cultiva feijão no Brasil. Entretanto, é de grande importância para a região nordeste (LUCCA Filho, 1984).

A disseminação do agente causal, Macrophomina phaseolina, verifica-se através de sementes com esclerócios e picnidiosporos formados nas partes infectadas das plantas, e através do solo contaminado. Condições de alta umidade e temperatura favorecem o seu desenvolvimento (COSTA, 1972; KI MATI, 1980) .

A doença inicia-se nas plântulas com pequenas lesões escuras, deprimidas, na base dos cotilédones. o pro- 
gresso do processo doença pode ser tão rápido que todo o cau le fica envolvido pela lesão. As lesões têm margens bem definidas, muitas vezes apresentam anéis concêntricos e, à medida que crescem, tornam-se cinzentas. Esse tipo de infecção frequentemente leva ao tombamento das plantas (COSTA, 1972).

d. Podridões radiculares do feijoeiro - Rhizoctonia solani e Fusarium solani f. phaseoli

Considerando a frequência encontrada em nosso meio, pode-se considerar uma doença importante; entretanto, por falta de estudos fica dificil estimar os prejuizos ocasionados à cultura (KIMATI, 1980). Tem sido comum encontrar , 5 a $10 \%$ de perdas e até mais, se as condições forem favoráveis; em feijão-fava atingem até 40\% (ZAMBOLIM \& CHAVES, 1978).

o agente causal é o fungo Rhizoctonia solani. A temperatura ótima do solo para formação de lesões no hipocótilo é de $18^{\circ} \mathrm{C}$. Nas sementes pode ser encontrado tanto interna como externamente (BOLKAN et alii, 1974; BOLKAN et alii,1976).

A doença pode provocar falhas na germinação, morte de plântulas, tanto em pré como em pós emergência, e podridão do caule, na forma de lesões pardo-avermelhadas, de primidas, bem delimitadas, alongadas no sentido do comprimen to do caule. O fungo pode atacar as raizes e o caule acima e abaixo da superfície do solo (COsTA, 1972).

Além desse patögeno, a podridão de raízes pode ser causada também por Fusarium solani f. phaseoli, que 
se manifesta inicialmente por uma coloração levemente avermelhada da raiz principal. A alteração da cor aumenta em intensidade e extensão, até quase a linha do solo, e raramente mais para cima. Posteriormente, as lesões tornam-se marrons, frequentemente acompanhadas por fissuras longitudinais. Raí zes adventicias podem se formar em resposta à destruição das raizes laterais (BOLKAN, 1980).

e. Murcha de Fusarium - Fusarium oxysporum f. sp. phaseoli

A doença, no Brasil, tem se mostrado mais importante para feijão-vagem que para feijão, sendo, possivelmente, uma das causas determinantes das mudanças periódicas das áreas de cultivo (KIMATI, 1980).

o agente causal, Fusarium oxysporum f. sp. phaseoli, habitante do solo, pode-se disseminar de um campo para outro, principalmente através de sementes contaminadas ou infectadas. Temperaturas amenas, em torno de $20^{\circ} \mathrm{C}$, favorecem o patógeno, porém seu ótimo de crescimento "in vitro" está em torno de $28^{\circ} \mathrm{C}$ (BOLKAN, 1980).

A infecção ocorre nas raízes e hipocótilo. o sistema vascular das plantas apresenta-se escurecido, podendo ocorrer uma obstrução dos vasos, o que causará os sintomas reflexos de perda de turgescência e amarelecimento das folhas (DONGO e MULLER, 1969). 


\section{f. Mancha de Levedura - Nematospora corylii}

Quando constatada no Brasil, em 1963, algumas amostras tiveram $100 \%$ de suas sementes afetadas. Hoje, ë mais dificil de se encontrar lotes com sintomas; a importân cia econômica da doença decorre da depreciação do produto de vido a sua deformação (KIMATI, 1980).

Insetos como percevejo verde (Nizara virudula) e hemipteros do gênero Lygus transmitem o agente causal, Nematospora corylii. A mancha de levedura manifesta-se somente nas sementes, na forma de manchas lisas, geralmente ro sadas, salientes, de forma e tamanho variáveis, de bordos de finidos; as manchas são acompanhadas, no centro, por perfura ções puntiformes provocadas pelos insetos vetores, os quais podem prejudicar diretamente as sementes pelas toxinas secre tadas. A temperatura ótima para infecção está em torno de 25 e $30^{\circ} \mathrm{C}$ (SCHWARTZ, 1980).

\section{g. Mancha de Alternária - Alternaria spp.}

E considerada uma doença de importância secun dária, de ocorrência mais comum em feijão-vagem. As espêcies de Alternaria são consideradas parasitas fracos, de ferimentos ou de tecidos velhos, quando expostos a períodos de alta umidade, durante 3 a 4 dias, e a temperaturas relativamente frias de 16 a $20^{\circ} \mathrm{C}$. Entre elas estão A. tenuis e A. brassicae f. phaseoli (SCHWARTZ, 1980). 
Os sintomas produzidos nas folhas são pequenas manchas pardo-avermelhadas rodeadas por um bordo mais es curo, as quais crescem lentamente, formando-se anéis concêntricos. Posteriormente, coalescem, tornam-se quebradiças, e o centro da lesão se desprende (SARTORATO et alii, 1983) .

DHINGRA (1978) encontrou Alternaria spp. como sendo um dos principais fungos em sementes de feijão-vagem, variando de 3 a $62 \%$, e em sementes de feijão comum de 0 a 17\%. GOMES \& DHINGRA (1983) encontraram a espécie A. alternata (A. tenuis) como sendo um sério patógeno de sementes de feijão-vagem (Phaseolus vulgaris) de coloração branca.

\subsubsection{DOENCAS BACTERIANAS}

a. Crestamento comum - Xanthomonas campestris pv. phaseoli

E uma doença bastante importante na época das águas, de distribuição cosmopolita, e que pode causar danos severos nas regiões de alta umidade e temperatura, condições favoráveis à disseminação e crescimento da bactéria Xanthomo nas campestris pv. phaseoli (VIEIRA \& SARTORATO, 1984).

NEERGAARD (1979a) relatou que a redução na pro dutividade causada pelo patógeno foi de $37 \%$ em 1958 e mais de 65\% em 1959, nos Estados Unidos. 
As sementes constituem o meio mais eficiente de disseminação do patógeno, podendo transportá-lo a longas distāncias, tanto externa como internamente à semente, perma necendo viável de 3 a 15 anos (SCHUSTER et alii, 1973).

A infecção origina pequenas manchas translúci das na face inferior das primeiras folhas. Mais tarde, ficam pardas, crescem, coalescem, e dão aspecto de queimadura. Geralmente surge um halo amarelado difuso e evanescente em torno das lesões iniciais; quando atingemas vagens, as ımanchas translūcidas aumentam de tamanho e tornam-se avermelhadas, as quais, frequentemente, se estendem ao longo do siste ma vascular indicando uma progressão para as sementes.

Essas, quando apresentam sintomas, perdem a coloração típica, enrugam-se, e adquirem aspecto envernizado. As manchas nos caules e pecíolos, inicialmente encharca das, tornam-se avermelhadas, afetando principalmente a região nodal do caule principal (COSTA, 1972; YOSHII, 1980) .

b. Crestamento fosco - Xanthomonas campestris pv. phaseoli var. fuscans

Causado pela bactéria Xanthomonas campestris pv. phaseoli var. fuscans, não se diferencia, quanto aos sin tomas e perdas no rendimento, do crestamento comum. Normalmente, a distinção somente é feita através de isolamentos; a 
caracteristica importante que distingue os dois patógenos é a capacidade de $x$. campestris pv. phaseoli var.fuscans de produzir um pigmento difuso de cor café, a melanina, em meio que contém tirosina (KIMATI, 1980).

No Canadá, $0,5 \%$ de sementes infectadas por $X$. campestris pv. phaseoli var. fuscans, foi suficiente para iniciar uma epidemia em feijoeiro (WALLEN \& SUTTON, 1965), a que mostra ser a semente veículo eficiente de disseminação e transmissão da bactéria.

c. Crestamento de halo - Pseudomonas phaseolicola

No Brasil, a doença foi relatada somente no Rio Grande do Sul, São Paulo e Minas Gerais. A bactéria fitopatogênica, Pseudomonas phaseolicola, é favorecida, ao con trário das duas anteriores, por temperaturas amenas. Os sin tomas são semelhantes aos outros crestamentos, diferenciando - se apenas pelo halo verde-amarelado de contorno bem definido em torno das lesões (COSTA, 1972).

Segundo KIMATI (1980), os crestamentos podem se desenvolver com extrema rapidez, mesmo com inöculo inicial baixo: 30 sementes com o patógeno por hectare, no caso do crestamento de halo, ou $0,5 \%$ de sementes, no caso do cres tamento fosco.

NEERGAARD (1979a) relata que, em média, 30 se 
mentes infectadas por Pseudomonas phaseolicola por hectare, foram suficientes para produzir epidemia numa região dos Estados Unidos, Wisconsin. CAFATI \& SAETTLER (1980) relataram que P. phaseolicola foi transmitida através de sementes de feijoeiro colhidas de um campo, no qual a doença não foi detectada durante a estação de crescimento.

\subsubsection{DOENCAS VIRÓTICAS}

a. Mosaico comum do feijoeiro - vírus do mosaico comum do feijoeiro

Sua importância geralmente é pequena, pela re sistência das cultivares utilizadas. A transmissão do vírus do mosaico comum do feijoeiro (BCMV), através das sementes,é a fonte de inóculo inicial mais importante, podendo ser encontrado no embrião e cotilédones, porém raramente no tegumento da semente; a porcentagem de transmissão pela semente pode variar de 3 a 95\%, segundo a cultivar e idade no momento da infeção, especialmente se ocorrer antes da floração (PHATAK, 1974) .

EKPO \& SAETTLER (1974) sugeriram que taxa de transmissão do vírus é alta pela semente devido à presença do vî rus infectivo dentro do embrião, pois alguns vírus como o mosai co do sul do feijoeiro, que tem um baixo indice de transmissão pela semente, e o virus do mosqueado clorótico do caupi, 
que não é transmitido por sementes, estão localizados princí palmente no tegumento, e a infectividade associada com embriões imaturos deve-se à contaminação externa do tegumento.

Os sintomas provocados pelo virus do mosaico comum do feijoeiro dependem muito da cultivar, da estirpe, da idade da planta e das condições ambientes. O BCMV pode produzir três classes de sintomas: mosaico, necrose sistêmica (raiz preta) e lesões locais. Os sintomas mais caracteristí cos do mosaico podem ser vistos nas folhas trifoliadas, que podem ser mal formadas e apresentar mosaicos, encrespamento e bolhas. Os foliolos infectados podem tornar-se mais estreitos e mais delgados que os foliolos normais, e com consi derável enrolamento para baixo (COSTA, 1972; PHATAK, 1974).

\section{b. Mosaico do Pepino e Mosaico do Sul}

São viroses já relatadas no Brasil, cujos agentes causais, o vírus do mosaico do pepino e o virus do mo saico do sul do feijoeiro, são também transmitidos através das sementes, embora em nossas condições, de importância mui to inferior ao mosaico comum do feijoeiro (GẢLVEZ, 1980; CUPERTINO et alii, 1982). 


\subsubsection{FungOS DE ARMAZENAMENTO}

KENNEDY (1979) relatarque as sementes produzi das no campo são, frequentemente, contaminadas, ou infecta das com os chamados fungos de campo, e com algumas bactérias, os quais raramente estão associados com deterioração de sementes em armazenamento. De acordo com DHINGRA (1984), quase todos os fungos que infectam as sementes no campo, anteriormente à colheita, requerem alta umidade relativa e teor de umidade das sementes em equilíbrio com a umidade relativa do ar em torno de 95 a $100 \%$. Quando as sementes sofrem seca gem para o armazenamento, os fungos de campo permanecem dormentes, ou morrem gradualmente. A taxa de morte depende da temperatura e umidade relativa do ambiente de armazenamento, do grau de infeção, e do teor de umidade das sementes.

As sementes, quando armazenadas, podem ser in vadidas pelos denominados fungos de armazenamento, os quais não invadem as sementes no campo, pois não sobrevivem à competição com outros fungos, e não toleram altas taxas de teor de umidade. Segundo KENNEDY (1979) e DHINGRA (1984), os fun gos de armazenamento compreendem os gêneros Aspergillus spp. e Penicillum spp. que afetam a qualidade das sementes, depen cendo das condições de armazenamento. Os fungos de arma zenamento são os principais responsáveis pela perda de viabi lidade das sementes, atacando preferencialmente o seu embrião. 
Muitas vezes, é possível determinar as condições anteriores de armazenamento, pela identificação e quantificação dos fungos de armazenamento que predominam na amos tra de sementes. Os danos causados por esses fungos podem ser evitados pelo controle das condições de armazenamento , tanto a baixa umidade como a baixa temperatura, por inibirem seu crescimento. A escassez de informações sobre o efeito das condições e tempo de armazenamento sobre a flora fúngica associada às sementes de feijoeiro foi observada pela presente revisão.

Segundo ZINK et alii (1976), alta umidade das sementes e alta temperatura de armazenamento foram prejudi ciais à germinação e ao vigor ảas sementes de feijoeiro, com reflexos negativos na emergência no campo e na prođução, principalmente nos períodos finais de armazenamento. Das con dições de armazenamento estudadas, $6,7 \%$ de umidade à $20^{\circ} \mathrm{C}$ e $14,2 \%$ de umidade à $30^{\circ} \mathrm{C}$ foram, respectivamente, as melhores e as piores condições de armazenamento.

Observa-se, pelos trabalhos já desenvolvidos, a importância de um manejo cuidadoso para produção de sementes sadias e vigorosas, desde seu desenvolvimento na planta-mãe atẽ seu estabelecimento num ambiente adequado no solo, compreendendo etapas importantes como colheita, secagem,trans porte, e armazenamento das sementes. A flora fúngica de parasitas ou saprófitas de sementes pode variar de acordo com 
as condições climáticas e condições de ambiente durante o a mazenamento.

2.3. Linhas de PESQUisa dA PATOLOgia de SEMENTES DE FEIJOE IRO

A patologia de sementes encontra-se atualmente, no Brasil, em desenvolvimento. Suas perspectivas cada vez mais crescentes, proporcionadas pelo desempenho dos pesquisadores, são evidentes e comprovadas pelos trabalhos desenvolvidos inicialmente, os quais vêm fornecendo subsídios importantes para continuidade e progresso da área. Todas as informações até agora obtidas são de elevada significância e mostram a preocupação de se acumular conhecimentos, a fim de se alcançar um dos principais objetivos da patologia, o controle das doenças causadas por patógenos associados às semen tes, através do estabelecimento de níveis de tolerância, ou de demais medidas de exclusão.

2.3.1. LeVAntamento DA SANIDADE DE SEMENTES E EFEITO DO LOCAL DE PRODUCÃO

A maior parte dos trabalhos já realizados no Brasil dizem respeito a levantamento de fungos associados às sementes de feijoeiro, produzidas diretamente pelos agricul- 
tores, ou seja, sementes não melhoradas.

RICHARDSON (1979 e 1981) descreve os seguintes microrganismos associados às sementes de Phaseolus vulga ris, considerados agentes causais de doenças economicamente importantes: Ascochyta spp., Colletotrichum lindemuthianum, Diaporthe phaseolorum var. sojae, Fusarium oxysporum, Macrophomina phaseolina, Isariopsis griseola, Sclerotina sclerotiorum, Corynebacterium flaccumfaciens, Pseudomonas phaseoli cola, P. syringae, Xanthomonas campestris pv. phaseoli, X.cam pestris pv. phaseoli var. fuscans e o virus do mosaico comum. Rhizoctonia solani só foi considerado economicamente importante para Phaseolus lunatus.

LASCA (1978) realizou um dos primeiros levantamentos de fungos associados às sementes de feijoeiro no Estado de São Paulo, registrando uma ampla flora fúngica em 43 amostras das cultivares Carioca, Bioo de Ouro, Chumbinho, Ro sinha, Piratão, Goiano Precoce, Iguaçu, Aeté 1 e Rico 23,com uma frequência maior de Fusarium equiseti, Macrophomina phaseolina, F. semitectum, Phoma sp., Diaporthe. phaseolorum var. sojal e Rhizoctonia solani, além dos contaminantes Alternaria tenuis, Penicillium sp. e Curvularia lunata. Foi ve rificado menor incidência de fungos nas amostras provenien tes do Estado de São Paulo que do Paraná, fato explicado pelas possiveis diferenças no resultado das técnicas utiliza das na produção de sementes para cada Estado, incluindo o controle de doenças no campo. Complementando as argumenta - 
ções da autora, condições climāticas de cada Estado, além do genótipo dos materiais, poderiam estar influindo conjuntamen te na incidência dos fungos.

ITO et alii (1981), numa primeira tentativa de localização de áreas adequadas para produção de sementes sadias de feijoeiro, efetuaram um levantamento da incidência de fungos nas sementes das seguintes localidades do Estado de São Paulo: Ribeirão Preto, Lorena, Guairra, Santa Fé do Sul e Rubinéia. Os fungos de maior incidência foram Fusarium spp., Alternaria spp. e Rhizoctonia solani, sendo que a frequência deles foi variável de variedade para variedade, de ano para ano, e de região para região.

WALDER (1976) avaliou a qualidade de sementes de feijoeiro utilizadas por agricultores de Minas Gerais, on de quase a totalidade deles produzem suas próprias sementes. A baixa qualidade das sementes, verificada pelo poder germinativo e vigor, através do envelhecimento precoce, emergêncía em campo, velocidade de germinação e peso médio da matéria seca, sugeriram a presença de microrganismos associados às sementes.

TANAKA \& DESLANDES (1978), MACHADO \& PITTIS (1983) e MELO (1980) avaliaram a sanidade de sementes de fe $\underline{i}$ joeiro produzidas em Minas Gerais. Nos dois primeiros traba lhos foram observados fungos importantes como C. lindemuthia 
num, M. phaseolina, R. solani e Fusarium spp. No terceiro trabalho foi observado grande incidência de fungos de armaze namento como Aspergillus sp. e Penicillium.

MENEZES et alii (1981) analisaram a sanidade de sementes de feijoeiro obtidas diretamente dos agricultores nos seus armazéns, ou durante a semeadura, através do mé todo de papel de filtro e papel toalha. Os fungos encontrados em grande número de sementes, causando principalmente po dridões foram: Alternaria sp., Botryodiplodia theobromae, Col letotrichum dematium, F. equiseti, F. moniliforme, F.semitec tum, Phomopsis sp., Phoma sp. e Trichothecium sp. A baixa por centagem de amostras da cultivar Rio Tibagi, infectadas com M. phaseolina, foi resultante do local de cultivo, sul do Es tado, onde as condições climáticas não são muito favoráveis ao desenvolvimento da doença.

OLIVEIRA (1984) avaliou a flora fúngica de se mentes de feijoeiro procedentes da região nordeste do Estado da Bahia, obtidas em armazéns de agricultores, por ocasiãoda semeadura. Doze amostras de diversas cultivares foram avaliadas através dos métodos de papel de filtro e plaqueamento em ăgar, onde 23 gêneros de fungos foram observados, entre eles, B. theobromae, C. lindemuthianum, M. phaseolina e $R$. solani. Os mais recuperados foram Aspergillus spp. (27,68), Fusarium spp. $(23,08)$ e M. phaseolina $(13,0 \%)$.

SANTOS et alii (1986) avaliaram a sanidade das sementes de feijoeiro do Estado do Espirito Santo, obtidas 
em algumas propriedades agrícolas, sob condições irradequadas de armazenamento. A análise realizada evidenciou a predominância de Fusarium spp., em cerca de 66,0\% das amostras. Va lores elevados foram encontrados para Aspergillus sp. $(71,0 \%)$, Penicillium sp. $(48,0 \%)$, Rhizopus sp. $(23,0 \%)$, Verticillium sp. $(15,0 \%)$ e outros. C. lindemuthianum foi constatado apenas em 2,7\% das amostras, apesar de ocorrer nos plantios de feijoeiro das regiões amostradas, principalmente na safra das secas.

\subsubsection{MetOdOLOgia de DETECCÃO DE Fungos}

Apesar da importância dos microrganismos asso ciados às sementes, muito pouco se sabe sobre como avaliar a sua qualidade. As análises de rotina em Laboratórios de Análise limitam-se às avaliações de qualidade fisiológica, porêm, a necessidade de aliar às análises de qualidade sanitária vem se ressaltando cada vez mais. Para isso, é preciso desenvolver técnicas simples e de custo não muito elevado, que possibilitem selecionar os melhores lotes de sementes.

Para a maioria das empresas particulares de sementes, a necessidade do teste é consequência da frequente reprovação de lotes, que por motivo de baixa germinação, não atingiram os padrões minimos estabelecidos pelas Normas de Produção de Sementes. O teste de sanidade poderia determinar a causa da baixa germinação, e até mesmo, orientar pạ 
ra um tratamento químico adequado (PEREIRA, 1984; TANAKA \& MACHADO, 1985) .

As pesquisas sobre métodos para detecção de microrganismos em sementes, a serem utilizadas em laboratórios de rotina, devem ser intensificados, uma vez que já se conhece a importância e necessidade de elaborar programas de certificação de sementes, nos quais sejam incluídos testes de sanidade e tolerâncias de infecção de sementes por patóge nos economicamente importantes (LASCA, 1984).

E grande a dificuldade em se avaliar a sanida de das sementes nos Laboratórios de Análise, pois se requer pessoal treinado e qualificado, um dos principais entraves para o avanço da patologia de sementes no Brasil (EIRA, 1984; TANAKA \& MACHADO, 1985). Os métodos para detecção de micror ganismos associados às sementes devem concentrar-se em dois pontos, ou seja, visar a detecção de um patógeno específico, e visar a deteç̧ão de patógenos sob condições especiais de teste de rotina. O primeiro caso deve atender às necessidades de laboratório de quarentena. Um método para deteç̧ão de microrganismos em semente deve atender a certos requisitos básicos como ser reproduzivel dentro de limites estatís ticos, os resultados devem dar informações seguras quanto à performance em campo ou às necessidades de quarentena, ser econômico quanto ao tempo, trabalho e equipamentos, e fornecer resultados rapidamente (SOAVE, 1984). 
Segundo NEERRGAARD (1979a), o método de papel de filtro é amplamente utilizado em testes de sanidade de se mentes, especialmente em circunstâncias onde o método do ágar é impraticável. Ele é aplicado a todos os tipos de sementes, incluindo sementes de cereais, vegetais, ornamentais e florestais. O método pode ser designado como um hỉbrido entre a câmara úmida utilizada em fitopatologia e o teste de germinação usado em tecnologia de semente. O método combina as vantagens de investigações "in vitro" com as observações "in vivo".

Segundo ANSELME (1979), o teste de rotina para o agente causal da antracnose, Colletotrichum lindemuthia num, ê feito com 400 sementes pré-tratadas com hipoclorito de sódio, com 8 repetições de 50 sementes em rolo de papel de filtro umedecido, num período de incubação de 9 dias. Após esse período, a epiderme das sementes germinadas é removida. As plântulas e cotilédones infectados mostram-se necrosadas. Para LEACH (1979), este método é muito bom também para Rhizoctonia solani, onde ocorre sintomas característicos de lesões alongadas. ANSELME (1979) relatou ainda que não há um método de rotina para detectar Pseudomonas phaseolicola e que somen te a observação nos campos é utilizada como critério para aceitar ou recusar o campo de produção de sementes.

ANSELME \& CHAMPION (1981) descreveram, para deteç̧ão de C. lindemuthianum, a inspeção direta e o rolo de 
papel toalha. Na inspeção direta as lesões nas sementes severamente infectadas podem ser marrons com centros esbranqu1 çados, circundadas por uma área marron claro a marron escuro, ou lesões avermelhadas de tamanhos/variāveis. Este método não é seguro, pois nem todas sementes infectadas mostram:sin tomas, e nas variedades de sementes escuras os sintomas difi cilmente são observados. No teste de germinação as sementes são imersas em uma solução de hipoclorito de sódio a 1\% durante 10 minutos e secas em seguida. Após o periodo de incu bação de 7 dias à $20^{\circ} \mathrm{C}$ no escuro, os tegumentos da semente são removidos para exame dos cotilédones a olho nu, visualizando-se āreas escuras e deprimidas de contorno bem definido.

Foi verificado por NEERGAARD (1979b) que para C. lindemuthianum as porcentagens de infecção à $20^{\circ} \mathrm{C}$ são sen sivelmente maiores que à $25^{\circ} \mathrm{C}$, durante os testes, uma vez que o fungo prevalece em regiões temperadas. Para o grupo de Fusarium spp. os resultados são iguais nas duas condições de temperatura; em testes com $\mathrm{BDA}$ à $20^{\circ} \mathrm{C}$, os resultados encontrados são semelhantes.

DHINGRA (1978) avaliou sementes de feijoeiro e de feijão-vagem produzidas em Minas Gerais pelo método do plaqueamento em BDA-estreptomicina após assepcia superficial das sementes com hipoclorito de sódio e etanol. Alguns fungos importantes foram recuperados: Macrophomina phaseolina, Rhizoctonia solani, Fusarium semitectum e Phomopsis $\mathrm{sp.}$ 
MACHADO \& PITTIS (1983) utilizaram os métodos do plaqueamentó em ägar, papel toalha em rolo e papel de fil tro para avaliar a sanidade de sementes de feijoeiro produzidas em Minas Gerais. Foi encontrado um maior indice de $C$. lindemuthianum no segundo método, que também mostrou-se eficiente na recuperação de $R$. solani.

OLIVEIRA (1984), analisando a sanidade de sementes de feijoeiro produzidas no Estado da Bahia, pelos mêtodos do papel de filtro e plaqueamento em BDA, encontrou maior porcentagem de fungos no primeiro método, embora M.pha seolina tenha sido recuperada principalmente em BDA.

LASCA (1978) obteve resultados semelhantes com respeito às espécies de fungos encontrados através dos métodos de papel de filtro e plaquemento em águar, embora houvesse maior frequência de amostras com Fusarium e C. lindemuthianum no primeiro teste, e maior frequência de amostras com M. phaseolina, R. solani e Diaporthe phaseolorum var. sojae no teste de plaqueamento em ágar (BDA).

\subsubsection{AVAliação de danOS causados POR FUngOS ASSO- CIADOS AS SEMENTES}

Há uma falta muito grande de dados quantitatí vos e qualitativos sobre danos e perdas causadas por microrganismos associados às sementes. Sabe-se que, muitas vezes, 
lotes de sementes são reprovados pela incidência elevada de plântulas infeccionadas e de sementes mortas, resultando em baixa porcentagem de germinação. Em sementes de feijoeiro tem-se observado o problema, principalmente com o fungo Rhizoctonia solani. CARDOSO et alii (1980), em comparações de lotes de sementes de feijoeiro, com e sem infeção de $R$. solani mostraram que os lotes infectados apresentavam uma germinação de $68,0 \%$ e um peso de 100 sementes de 12,2 g, enquanto as sementes não infectadas $93,0 \%$ e 22,2 g respectivamente.

Os microrganismos podem atuar tanto interna como externamente às sementes, e tornam-se ativos assim que as sementes são depositadas no solo. Estas podem apodre cer antes de germinar, como acontece com Phomopsis sojae em soja e Fusarium semitectum em sementes de feijão-vagem; ou então, o patógeno poderá atacar a plântula, a exemplo de Col letotrichum dematium f. sp. truncata em soja

(DHINGRA， 1978).

Os patögenospodem infectar as sementes sistemi camente, reduzindo seu vigor e só manifestando sintomas quan do as plantas estiverem adultas, como no caso de carvões, on de os grãos, ao serem formados, têm muitas vezes o seu conteúdo substituído por massa negra de esporos; outros podem não infectar as sementes sistemicamente, como no caso da an- 
tracnose da soja e feijoeiro, dependendo do tipo de ataque (DHINGRA, 1978) .

Segundo Sinclair, citado por MENTEN (1978), o aumento do potencial de germinação no teste de envelhecimento acelerado, pelo tratamento das sementes com fungicidas, de monstra que muito do vigor da semente está relacionado com a presença de patógenos. MENTEN (1978) demonstrou que houve correlação entre a incidência de microrganismos pelo método do papel de filtro e o teste de germinação e vigor.

DHINGRA (1978) relatou a importāncia subestimada de Phomopsis sp. como um dos principais fungos reduzindo a qualidade de sementes de feijoeiro. ELLIS et alii (1976) obtiveram resultados de Phomopsis sp. prejudicando a qualidade das sementes quando estavam com $12 \%$ de infeção. Alēm de Phomopsis, sementes de feijoeiro com $F$. semitectum, M. phaseolina e $R$. solani, não germinaram.

Outros tipos mais comuns de danos já citados por NEERGAARD (1979a), causados. por saprófitas ou patógenos, incluem alterações de cor, necrose da semente e redução do tamanho, os quais depreciam o valor comercial das sementes e grãos.

Foi verificado por DHINGRA \& MUCHOVEJ (1979), que em um campo de produção de sementes de Minas Gerais, du- 
rante um periodo prolongado de chuva, uma podridão da vagem e da semente de feijão-vagem, causada por Fusarium semitctum, ocasionou uma perda total de cultivo. Sob condições in termitentes de alta umidade em casa de vegetação, formaram-se lesões circulares e alongadas, de cor café, durante o teste de patogenicidade em vagens inoculadas.

MENTEN et alii (1979) observaram a ocorrência da mancha de levedura em sementes de feijoeiro, causado por Nematospora corylii, afetando sua qualidade. Os resultados do estudo mostraram que as sementes com mancha tiveram a germinação, o vigor e o peso reduzidos em relação às sementes sem mancha, das cultivares Carioca e Rosinha G-2; verifi cou-se também, que as sementes com mancha apresentaram maior incidência de Alternaria sp.

2.3.4. EPIdEMIOLOgia E estabelecimento DE NIVEIS DE TOLERÂNCIA DE PATÓGENOS ASSOCIADOS AS SEMEN TES

A associação intima entre sementes e patógenos é bastante importante como mecanismo de sobrevivência do patógeno, como meio de introduzi-lo em culturas jovens, em 
novas áreas, e como meio de introduzir diferentes raças do patógeno em novas āreas. No entanto, conforme discute BERGA MIN Filho (1984), o fato das sementes estarem infectadas,não significa, necessariamente, que haverá uma epidemia quando estas sementes forem levadas ao campo.

Hoje é clara a necessidade, dentro da patologia de sementes, de se estabelecer padrões de tolerância para sanidade de sementes. SOAVE (1984) e BERGAMIN Filho (1984) relataram que, para obtenção desses padrões, é preciso relacionar a taxa de inóculo inicial na semente e o desen volvimento da doença no campo até a taxa de redução da colheita e a taxa de reestabelecimento do inóculo na semente. A realização de análise sanitária de sementes em laboratório de rotina, para certificação, só se justifica se existir padrão de tolerância para determinado patógeno de determinada cultura.

O nível de tolerāncia é o grau máximo de incí dência de um patógeno na semente, que não venha causar danos econômicos à cultura. Este, pode variar dependendo de värios fatores: interação planta-patógeno, método de análise u tilizado, destino geográfico do lote de sementes, densidade de semeadura e possibilidade de tratamento quimico (NEERGAARD, 1979a). O autor sugere que se estabeleça níveis a partir de um esquema de certificação regional. Em consequên 
cia do grande nümero dos fatores envolvidos na interação planta-patógeno, o êxito alcançado com este tipo de trabalho tem sido muito pequeno (MENEZES, 1984). Ocorre que, nem mes mo esses fatores estão bem estudados, para que se possa esta belecer quantitativamente o patógeno na semente, exemplifica dos pela falta de zoneamento agrícola para a seleção das melhores áreas de produção de sementes, metodologia de detec ção dos patógenos e outros.

Segundo DHINGRA et alii (1986), os niveis de tolerância de colletotrichum lindemuthianum devem variar dependendo da raça do patógeno e ser inclusive reduzido a zero. Niveis de tolerância em alguns paises são de apenas $2 \%$ nas sementes, os quais se baseiam mais nas análises de sementes, do que na prevalência da doença nos campos de produção.

DHINGRA et alii. (1986) relataram que no Brasil, um campo de feijão destinado à produção de sementes pode ser rejeitado se a prevalência da antracnose no campo ocorrer entre 0,5 e 4,0\% dependendo do Estado; no entanto, a análise em laboratório não é realizada. Seu estudo, com uma combinação apenas de uma raça-cultivar, mostrou que a prevalência de antracnose nas folhas da cultivar Manteigão Fosco variou de 0 a $62,7 \%$ e nas vagens de 0 a $52,7 \%$ conforme 0 lo cal e a estação. A porcentagem de sementes transmissiveis de $C$. lindemuthianum variou de 0 a 4,2\%, dependendo do local 
e da estação (chuvosa ou não chuvosa). A prevalência da doença nas folhas durante a estação chuvosa foi alta, apesar de que a prevalência da doença nas vagens e a infestação de sementes pelo patógeno foi baixa. Na estação não chuvosa a prevalência de doença nas folhas foi mais baixa, mas nas vagens e nas sementes foi mais alta. Similarmente, a proporção de sementes transmissíveis do patógeno, produzidas duran te a estação chuvosa, foi consideravelmente menor que a produzida na estação não chuvosa.

GREGORY et alii (1959) esclarecem esses resul tados, pois, durante a estação chuvosa, devido à alta temperatura e umidade, as plantas têm crescimento foliar exuberan te, o qual, alēm de proteger as vagens, também reduz a força de impacto das gotas de chuva, reduzindo a disseminação local do patógeno.

Wallen, citado por NEERGAARD (1979a), relatou a importância de três patógenos na relação de transmissão por sementes de ervilha e perdas de produtividade, mostrando reduções diferentes na produtividade, de acordo com o grau de severidade na semente, para cada patógeno. Os resultados sugeriram que o nivel de tolerância de Ascochyta pisi na semente, pode ser quatro vezes maior que de Mycosphaerella pinodes, e duas vezes maior que de Phoma medicaginis var. pinodella. No Canadá, a tolerância estabelecida para as 
sementes é de 6\% para A. pisi, e apenas $2 \%$ para os outros dois patógenos em combinação.

NEERGAARD (1979a) citou que 0,02용 de sementes infectadas por Pseudomonas phaseolicola poderiam causar uma epifitia. No Canadá, WALLEN \& SUTTON (1965) observaram que apenas $0,5 \%$ de sementes de feijoeiro com Xanthomonas campesthis pv. phaseoli var. fuscans foram suficientes para causar epifitia. Os autores ressaltaram a necessidade de obter-se tolerância zero ao patógeno no material de propagação armaze nado.

WALLEN \& GALWAZ (1979) verificaram a transmissão de Xanthomonas campestris pv. phaseoli por sementes e a sobrevivência da bactéria por longo período em sementes ar mazenadas, a $18-32^{\circ} \mathrm{C}$, nos dois primeiros anos e a $-18^{\circ} \mathrm{C}$ por mais quatro anos. Após os 6 anos, produziu-se campos infectados.

\subsubsection{CONTROLE DAS DOENGAS}

As medidas envolvidas para controle das doenças, cujos patógenos são transmitidos por sementes, incluem principalmente a exclusão através de quarentena, esquema de 
certificação de sementes, escolha de áreas propícias à produ ção de sementes, uso de cultivares resistentes, controle quI mico, épocas de semeadura e colheita. No que se refere a se mentes de feijoeiro, os estudos visando controle dessas doen cas têm sido em número bastante baixo, especialmente a nível nacional.

ELLIS \& GĀLVEZ (1980) indicaram como região favorável à produção de sementes livres de patógenos, quando a precipitação ocorrer abaixo de $300 \mathrm{~mm}$, a umidade relativa diária inferior a $60 \%$, temperaturas diārias entre 25 e $35^{\circ} \mathrm{C}$, irrigação por infiltração, e região não utilizada para plantio comercial de feijão.

VIEIRA \& SARTORATO (1984) relataram que a escassez de chuvas e a baixa umidade relativa do ar propiciam condições desfavoráveis aos agentes do crestamento bacteriano comum e da antracnose, o que possibilita, em regiões com essas características, a produção de sementes livres desses patógenos. O vỉrus do mosaico comum e seus vetores são capa zes, entretanto, de sobreviver a essas condições, tornando-se necessário o controle de insetos, ou o plantio de variedade resistente.

Yerskes \& Crispin, citados por RAVA et alii (1981) constataram a não transmissão de colletotrichum linde 
muthianum quando a semente infectada foi cultivada em regiões áridas do México durante o inverno, utilizando irrigação por infiltração.

AZEVEDO \& LAUDARES Filho (1982) recomendam a máxima cautela e rigoroso controle sanitário das lavouras do periodo das águas. As áreas destinadas à produção de sementes de feijoeiro devem ser as mais secas possiveis, adotando - se preferentemente os plantios da seca (janeiro a feverei ro) e de inverno (maio a junhol com o uso de irrigação. Ain da, considerado pelos mesmos autores, a área escolhida para instalação do campo de produção dé sementes não deve ter sido cultivada com feijão nos dois anos anteriores, salvo se o novo plantio foi com a mesma cultivar. Deve-se evitar o uso de locais onde tenha sido comprovada a ocorrência de doenças, pois os patógenos, como os causadores da antracnose, da mancha angular e das bacterioses, possivelmente presentes nestes solos, podem sobreviver em restos de cultura disseminando-se posteriormente através das sementes ali obtidas. A gleba escolhida deve também ser favorável à prática de irrigação, bem como apresentar baixa incidência de plantas daninhas.

ASMUS \& DHINGRA (1985) mostraram diferenças entre cultivares quanto à reação a patógenos foliares e radi culares, possivelmente pela variação quanto à suscetibilida- 
de a patógenos em sementes, independentes das condições climáticas e regiões produtoras. Os resultados encontrados no estudo mostraram que as cultivares Rico 23 e Carioca produzi ram somente 1 응 de sementes infectadas por $C$. Lindemuthianum, enquanto a cultivar Bolinha produziu 15\% de sementes infecta das pelo patógeno.

Quanto às recomendações sobre tratamento químico de sementes de feijoeiro, a literatura também é bastante escassa. KORE \& SOLANKE (1982) verificaram a eficiência de fungicidas na microflora de feijoeiro, onde todos os tratamentos quimicos reduziram-na, porém a porcentagem de germi nação foi maior nas sementes tratadas com (Agrosan GN), Carboxin (Vitavax) e Carbendazim (Bavistin). A germinação diminuiu e a microflora aumentou com o tempo de armazenamento após tratamento.

ELLIS \& GALVES (1980) citam os fungicidas pro tetores como Captan e Thiram penetrando no tegumento da semente de feijoeiro, onde se encontram muitos fungos, mas não no interior dos cotilédones. A dose recomendada na maioria dos casos é de 100 a $200 \mathrm{~g}$ do produto por $100 \mathrm{~kg}$ de sementes. Os fungicidas sistêmicos, como o Benomyl, podem penetrar no tegumento e nos cotilédones, e proporcionar certo grau de controle.

Benomyl ou Tiofanato metilico, em associação com captan em tratamento de sementes de feijoeiro mostraram 
excelente controle de C. Lindemuthianum, durante 1977 e 1978 nos Estados Unidos (EDGINGTON et alii, 1980)。

TANAKA \& CORREA (1982) estudaram o efeito do tratamento de sementes de feijoeiro com fungiicidas e antibiôticos sobre a emergência e "stand". Verificou-se que a germinação e emergência das sementes de baixa qualidade foram ele vadas por Carbendazim + Streptomicina; em sementes de alta qualidade, o tratamento com Thiram, Carbendazim, Carbendazim + Streptomicina, Benomyl e Quintozene + Streptomicina aumentaram a emergência.

Considerando-se que, os níveis de tolerância para bactérias em campo são extremamente baixos, e não existe tratamento de sementes com fungicidas que controle totalmente as bactérias alojadas no seu interior, uma das poucas opções seria a instalação de campos de produção de sementes em regiões que apresentem condições climáticas adversas de temperatura e umidade (NEERGAARD, 1979a; ELLIS \& GALVÉz, 1980; VIEIRA \& SARTORATO, 1984).

Não existe tratamento quimico disponivel para eliminação de vírus nas sementes (VIEIRA \& SARTORATO, 1984).

Percebe-se, pelas recomendações dos autores, a preocupação e a importância de se controlar as doenças da cultura através dos princípios da exclusão, erradicação e evasão, ou seja, uso de sementes sadias, tratamento químico de 
sementes, escolha de locais desfavoráveis e livres do patóge no, e ainda, com baixa ocorrência de plantas daninhas, que poderiam ser fonte de inóculo para importantes doenças. Por outro lado, o fato das sementes estarem contaminadas ou infectadas, nem sempre quer dizer que haverá necessariámente uma epidemia no campo.

Além da utilização de sementes sadias ser prạ tica indispensável para bom desenvolvimento da cultura, outro exemplo de controle dentro do princípio de exclusão bastante fundamental para a patologia de sementes é a quarentena. ROCHA (1984) define como sendo uma atividade que visa excluir de uma região ou pais, pragas e enfermidades de significante importância para a agricultura, a qual representa uma das importantes facetas nos programas nacionais de controle ou manejo integral de pragas e doenças. As medidas de quarentena não devem ser estáticas ou definitivas, elas devem ser alteradas sempre que as condições mudarem, ou novos fatos se tornarem evidentes. 


\section{MATERIAL E MÉTODOS}

3.1. Caracterizaç̃o das amostras de sementes analisaDAS

Os testes de sanidade das sementes foram realizados no laboratório de Patologia de Sementes do Departamento de Fitopatologia, concomitantes aos testes de germinação e envelhecimento acelerado no laboratôrio de Tecnologia. de Sementes do Departamento de Agricultura e Horticultura da Escola Superior de Agricultura "Luiz de Queiroz", desde meados de 1984, até início de 1986.

As amostras de sementes de feijoeiro de aproximadamente $500 \mathrm{~g}$, foram coletadas ao acaso e abrangeram a safra da seca de 1984, das águas de 1984/85 e de inverno de 1985, provenientes de 46 diferentes municípios do Estado de são Paulo, onde as sementes foram multiplicadas. As semen- 
tes foram mantidas, após a coleta até o momento de execução dos testes, em câmara seca. Os diversos municípios amostrados foram agrupados em 13 regiões. Tais municípios e suas respectivas regiões, estão indicados na Figura 1. O agrupamento foi baseado conforme as divisões do Serviço de Produção de Sementes (SPS) do Estado, de maneira que cada região apresentou um sps. O nome de cada região refere-se à sede de cada SPS. Os municipios sedes são aqueles hachurados na Figura 1: Aguai, Araçatuba, Avaré, Bauru, Fernandópolis, Ibitinga, Itapetininga, Jaboticabal, Paraguaçu-Paulista, Pirassununga, Presidente Prudente, Ribeirão Preto e Tatuí.

O número de municípios amostrados que estão representando as regiões são variáveis, e estão identifica dos, assim como a caracterização das sementes, nos items 3 . 1.1 (feijão da seca), 3.1.2 (feijão das águas) e 3.1.3 (feijão de invernol. As sementes utilizadas englobaram as classes de sementes genéticas, bāsicas e certificadas geração A, B, e X, das cultivares Carioca e Carioca-80, totalizando 133 amostras, das quais 34 foram produzidas na seca, 26 nas "āguas e 73 no inverno. As épocas de produção mais indicadas para cada região estão representadas nas Figuras 2, 3 e 4 , respectivamente. Tais épocas, de acordo com suas caracterís ticas, seguem basicamente o ZONEAMENTO AGRICOLA DO ESTADO DE SÃO PAULO (1977), que divide o Estado em 3 faixas de aptidão ćlimática para feijão: faixa A que corresponde às regiões ap tas à produção nas águas, faixa B que corresponde às regiões 


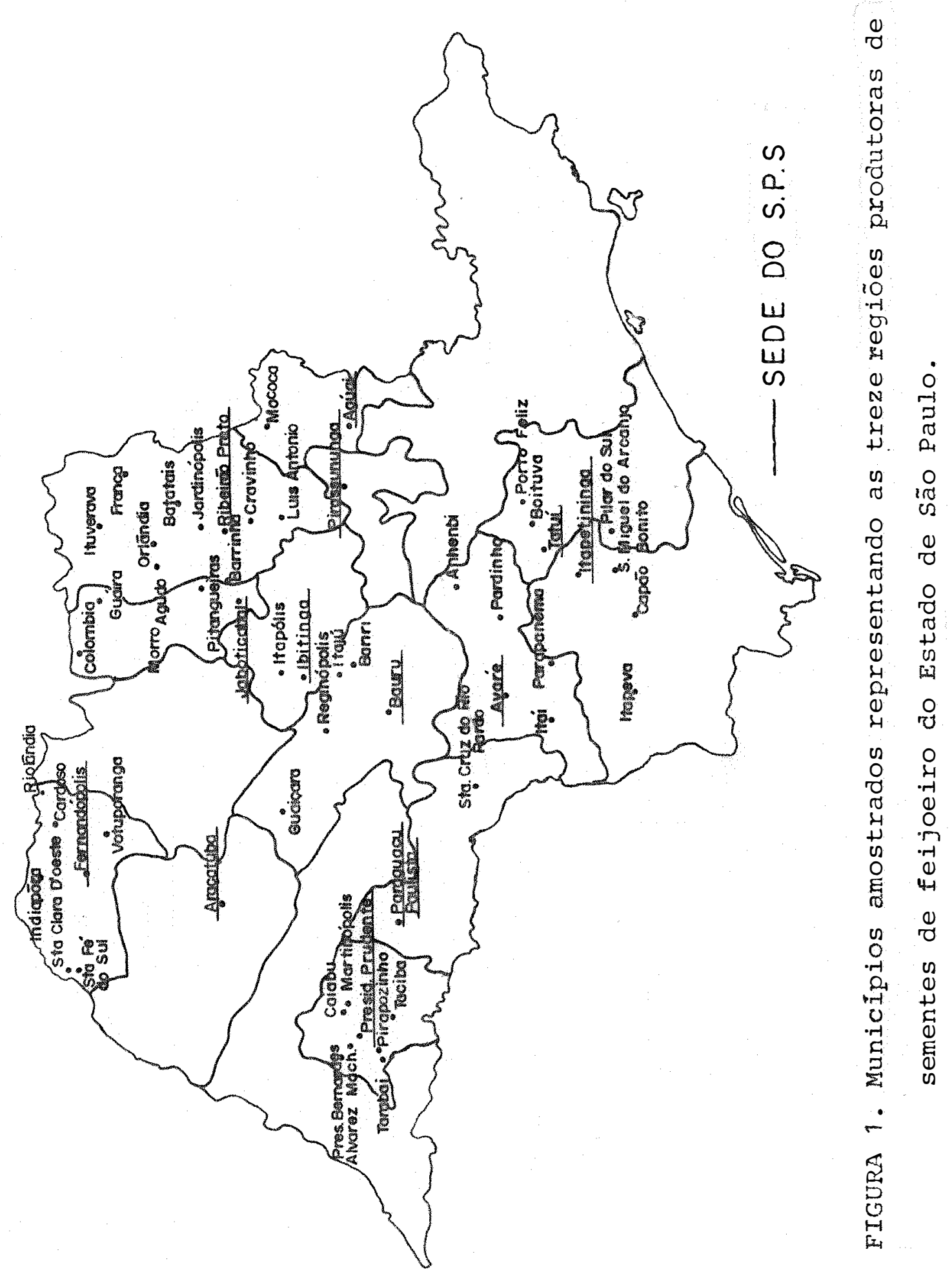




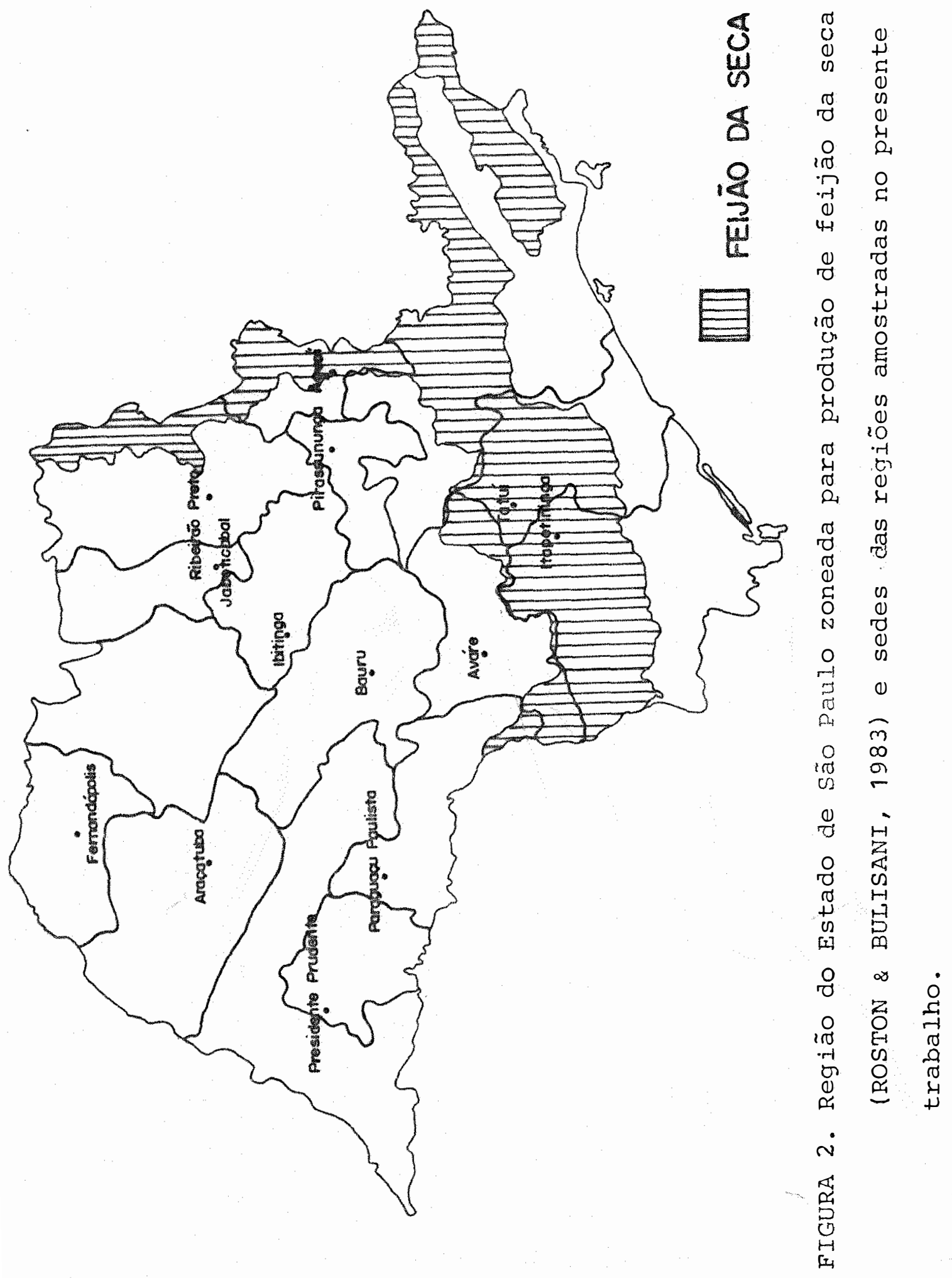


.46.
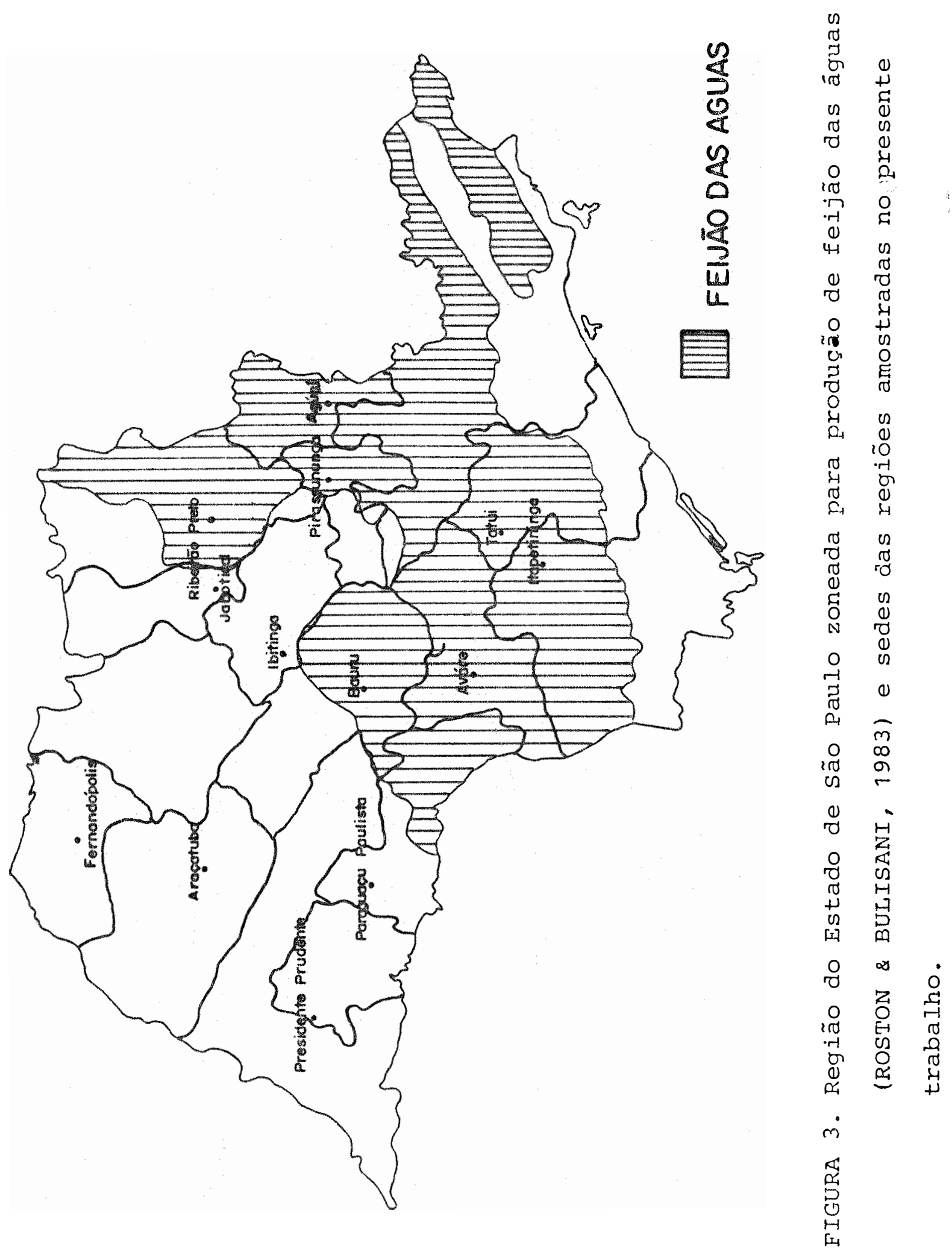


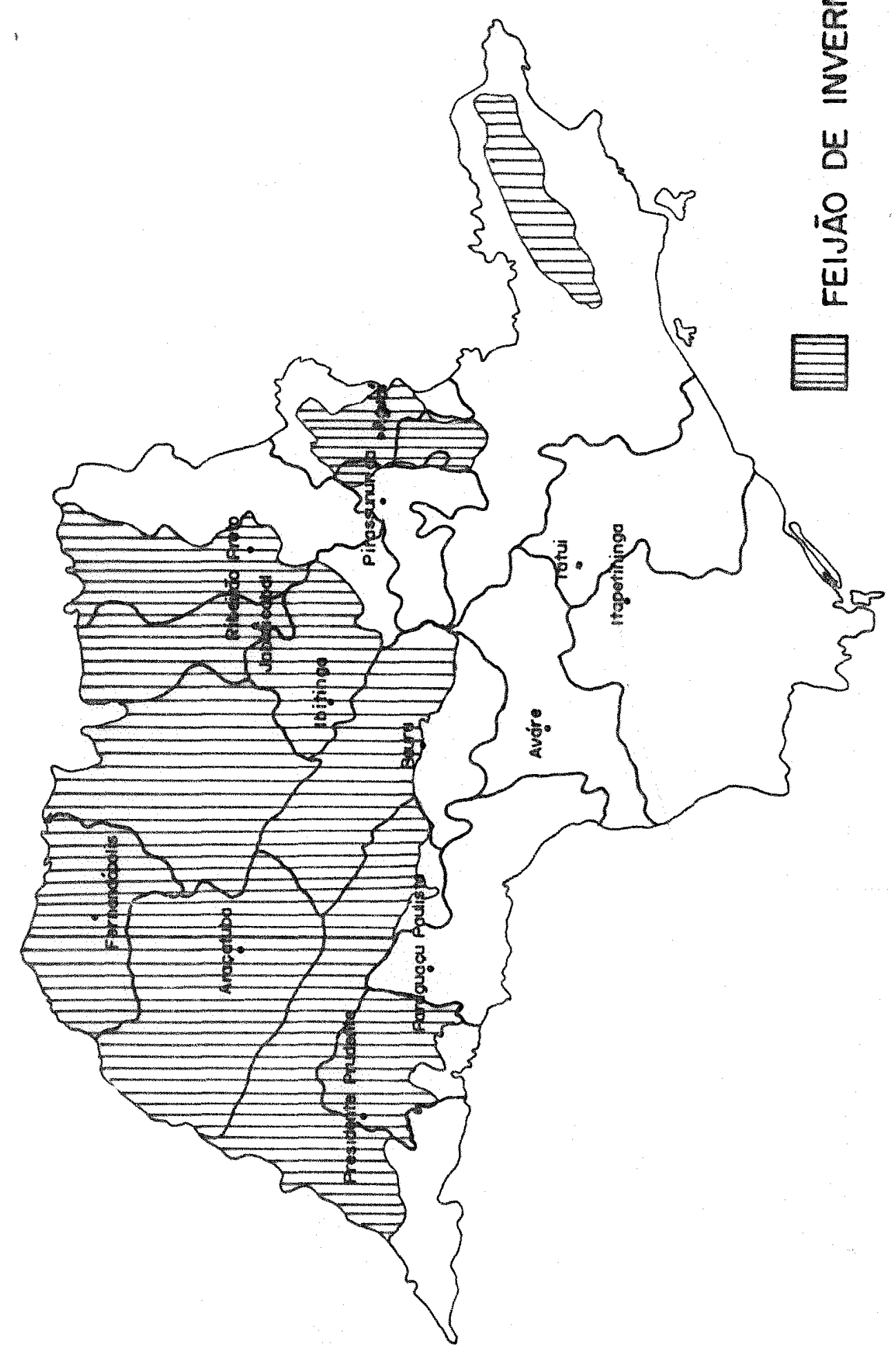

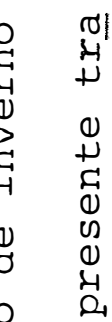

等

- 1 \&

4 O

๗

- H

in

ரु

मे 0

\%

가

त)

$\begin{array}{ll}\sigma & 0 \\ \pi & \sigma\end{array}$

(1)

$\begin{array}{ll}0 & 0 \\ 0 & 0 \\ 0 & 0 \\ 0 & 0\end{array}$

त) क

त

$\begin{array}{ll}0 & m \\ 0 & \infty \\ 10 & \text { a }\end{array}$

(1)

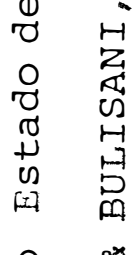

이

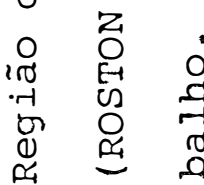

$\dot{\nabla}$

䍃

$\stackrel{D}{9}$

F. 
aptas à produção na época da seca e faixa c apta à produção no inverno com irrigação.

3.1.1. Caracterizaç̃o das amostras de SEMENTES. DE FEIJOEIRO PRODUZIDAS NA SAFRA DA SECA DE 1983

\begin{tabular}{|c|c|c|c|c|}
\hline Regiões & $\begin{array}{l}\text { No de } \\
\text { amos- } \\
\text { tras }\end{array}$ & Municípios & Cultivares & $\begin{array}{l}\text { Classes de } \\
\text { certificação }\end{array}$ \\
\hline
\end{tabular}

$\begin{array}{lllll}\text { 1. Araçatuba } & 1 & \text { Araçatuba } & \text { Carioca } & \text { Certificada-X } \\ 2 & \text { Araçatuba } & \text { Carioca } & \text { Certificada-X } \\ 3 & \text { Araçatuba } & \text { Carioca } & \text { Certificada-X } \\ & 4 & \text { Araçatuba } & \text { Carioca } & \text { Certificada-X }\end{array}$

\begin{tabular}{|c|c|c|c|c|}
\hline \multirow[t]{8}{*}{ 2. Avarē } & 1 & Itaí & Carioca & Certificada-A \\
\hline & 2 & Itai & Carioca & Certificada $-A$ \\
\hline & 3 & Avaré & Carioca & Certificada-A \\
\hline & 4 & Paranapanerna & Carioca & Certificada-A \\
\hline & 5 & Paranapanema & Carioca & Certificada-A \\
\hline & 6 & Paranapanema & Carioca & Certificada-A \\
\hline & 7 & Paranapanema & Carioca & Certificada-A \\
\hline & 8 & Pardinho & Carioca & Certificada-A \\
\hline
\end{tabular}

4. Fernandópolis 1 Santa Clara D'Deste Carioca-80 Certificada-A 2 Santa Fé do Sul Carioca Certificada-A 


\begin{tabular}{|c|c|c|c|c|}
\hline Regiöes & $\begin{array}{l}\text { No de } \\
\text { amos- } \\
\text { tras }\end{array}$ & Municípios & Cultivares & $\begin{array}{l}\text { Classes de } \\
\text { certificação }\end{array}$ \\
\hline \multirow{8}{*}{ 5. Itapetininga } & 1 & Capão Bonito & Carioca-80 & Certificada-A \\
\hline & 2 & Capão Bonito & Carioca-80 & Genētica \\
\hline & 3 & Capāo Bonito & Carioca-80 & Genética \\
\hline & 4 & Capäo Bonito & Carioca-80 & Genética \\
\hline & 5 & Capão Bonito & Carioca-80 & Genética \\
\hline & 6 & Itapetininga & Carioca & Certificada-A \\
\hline & 7 & Itapeva & Carioca-80 & Certificada-A \\
\hline & 8 & São Miguel Arcanjo & Carioca-80 & Certificada-A \\
\hline \multirow[t]{4}{*}{ 6. Jaboticabal } & 1 & Colómbia & Carieca-80 & Certificada-A \\
\hline & 2 & Colânbia & Carioca-80 & Certificada-A \\
\hline & 3 & Colômbia & Carioca-80 & Certificada-A \\
\hline & 4 & Jaboticabal & Carioca-80 & Certificada-A \\
\hline \multirow[t]{7}{*}{ 7. Tatuí } & 1 & Porto Feliz & Carioca & Certificada-A \\
\hline & 2 & Tatuí & Carioca & Certificada-A \\
\hline & 3 & Tatui & Carioca & Certificada-A \\
\hline & 4 & Tatui & Carioca & Certificada-A \\
\hline & 5 & Tatuí & Carioca & Certificada-A \\
\hline & 6 & Tatuí & Carioca & Certificada-A \\
\hline & 7 & Tatui & Carioca & Certificada-A \\
\hline Total & 34 & 13 & 2 & 3 \\
\hline
\end{tabular}


3.1.2. CaRACTERIZACÃO DAS AMOSTRAS DE SEMENTES DE FEIJOEIRO PRODUZIDAS NA SAFRA DAS ÁGUAS DE 1984/85.

\begin{tabular}{|c|c|c|c|c|}
\hline Regiões & $\begin{array}{l}\text { No de } \\
\text { amos- } \\
\text { tras }\end{array}$ & Municipios & Cultivares & $\begin{array}{l}\text { Classes de } \\
\text { certificação }\end{array}$ \\
\hline \multirow[t]{4}{*}{ 1. Aguai } & 1 & Aguai & Carioca-80 & Certificada-A \\
\hline & 2 & Aguaí & Carioca-80 & Certificada-A \\
\hline & 3 & Aguaí & Carioca-80 & Certificada-A \\
\hline & 4 & Aguai & Carioca-80 & Certificada-A \\
\hline \multirow[t]{4}{*}{ 2. Avaré } & 1 & Anhembi & Carioca & Certificada-B \\
\hline & 2 & Anhembi & Carioca & Certificada-B \\
\hline & 3 & Paranapanema & Carioca & Certificada-B \\
\hline & 4 & Paranapanema & Carioca & Certificada-B \\
\hline \multirow[t]{8}{*}{ 3. Itapetininga } & 1 & Capão Bonito & Carioca-80 & Certificada-A \\
\hline & 2 & Itapetininga & Carioca-80 & Certificada-A \\
\hline & 3 & Itapeva & Carioca-80 & Certificada-A \\
\hline & 4 & Itapeva & Carioca-80 & Certificada-B \\
\hline & 5 & São Miguel Arcanjo & Carioca-80 & Certificada-A \\
\hline & 6 & São Miguel Arcanjo & Carioca-80 & Certificada-A \\
\hline & 7 & São Miguel Arcanjo & Carioca-80 & Certificada-A \\
\hline & 8 & São Miguel Arcanjo & Carioca-80 & Certificada-A \\
\hline \multirow{4}{*}{$\begin{array}{l}\text { 4. Paraguaçu- } \\
\text { Paulista }\end{array}$} & 1 & Paraguaçu-Paulista & Carioca-80 & Certificada-A \\
\hline & 2 & Santa Cruz do R.Pardo & Carioca-80 & Básica \\
\hline & 3 & Santa Cruz do R.Pardo & Carioca-80 & Certificada-A \\
\hline & & & & continua \\
\hline
\end{tabular}




\begin{tabular}{lcccc}
\hline Regiões & $\begin{array}{c}\text { No de } \\
\text { amos- } \\
\text { tras }\end{array}$ & Municipios & Cultivares & $\begin{array}{c}\text { Classes de } \\
\text { certificação }\end{array}$ \\
\hline $\begin{array}{l}\text { 4. Paraguaçu- } \\
\text { Paulista }\end{array}$ & 4 & Santa Cruz do R. Pardo & Carioca-80 & Certificada-A \\
\hline 5. Tatui & 5 & Santa Cruz do R. Pardo & Carioca-80 & Certificada-A \\
& 1 & Boituva & Carioca & Certificada-A \\
& 2 & Pilar do Sul & Carioca & Certificada-A \\
& 3 & Tatui & Carioca & Certificada-A \\
& 4 & Tatui & Carioca & Certificada-A \\
& 5 & Tatui & Carioca & Certificada-A \\
\hline Total & 26 & 10 & 2 & 3 \\
\hline
\end{tabular}

3.1.3. CARACTERIZACÃO DAS AMOSTRAS DE SEMENTES DE FEIJOEIRO PRODUZIDAS NA SAFRA DE INVERNO DE 1985

\begin{tabular}{|c|c|c|c|c|}
\hline Regiões & $\begin{array}{l}\text { No de } \\
\text { amos- } \\
\text { tras }\end{array}$ & Municipios & Cultivares & $\begin{array}{l}\text { Classes de } \\
\text { certificação }\end{array}$ \\
\hline \multirow[t]{5}{*}{ 1. Aguaí } & 1 & Aguaí & Carioca-80 & Básica \\
\hline & 2 & Aguai & Carioca-80 & Bāsica \\
\hline & 3 & Aguaí & Carioca-80 & Básica \\
\hline & 4 & Aguai & Carioca-80 & Certificada-A \\
\hline & 5 & Aguai & Carioca-80 & Certificada-A \\
\hline
\end{tabular}




\begin{tabular}{lllll}
\hline Regiöes & $\begin{array}{l}\text { No de } \\
\text { amos- } \\
\text { tras }\end{array}$ & Municipios & Cultivares & $\begin{array}{c}\text { Classes de } \\
\text { certificação }\end{array}$ \\
\hline 1. Aguai & 6 & Aguai & Carioca-80 & Certificada-A \\
7 & Aguai & Carioca-80 & Certificada-A \\
& 8 & Aguai & Carioca-80 & Certificada-A \\
& 9 & Aguai & Carioca-80 & Certificada-A \\
& 10 & Aguai & Carioca-80 Certificada-A \\
11 & Mococa & Carioca-80 Genética
\end{tabular}

2. Bauru

1 Bariri

Carioca-80 Certificada-A

2 Bariri

Carioca-80 Certificada-A

3 Bauna

Carioca-80 Certificada-A

4 Guaiçara

Carioca-80 Básica

5 Guaiçara

Carioca-80 Básica

6 Guaiçara

Carioca-80 Básica

7 Guaiçaxa

Carioca-80 Básica

8 Guaiçara

Carioca-80 Básica

$9 \quad$ Itaju

Carioca-80 Básica

10 Itaju

Carioca-80 Certificada-A

3. Fernandópolis 1 Cardoso

Carioca-80 Certificada-A

2 Fernandōpolis

Carioca-80 Certificada-A

3 Indiaporã

Carioca-80 Certificada-A

4 Riolândia

Carioca-80 Certificada-A

5 Riolândia

Carioca-80 Certificada-A

6 Riolāndia

Carioca-80 Certificada-A

- continua - 


\begin{tabular}{|c|c|c|c|c|}
\hline Regiões & $\begin{array}{l}\text { No de } \\
\text { amos- } \\
\text { tras }\end{array}$ & Municípios & Cultivares & $\begin{array}{l}\text { Classes de } \\
\text { certificação }\end{array}$ \\
\hline \multirow[t]{3}{*}{ 3. Fernandópolis } & 7 & Riolândia & Carioca-80 & Certificada-A \\
\hline & 8 & Votuporanga & Carioca-80 & Certificada-A \\
\hline & 9 & Votuporanga & Carioca-80 & Certificada-A \\
\hline \multirow[t]{10}{*}{ 4. Ibitinga } & 1 & Ibitinga & Carioca-80 & Bâsica \\
\hline & 2 & İbitinga & Carioca-80 & Básica \\
\hline & 3 & Ibitinga & Carioca-80 & Básica \\
\hline & 4 & Ioitinga & Carioca-80 & Básica \\
\hline & 5 & Ibitinga & Carioca-80 & Certificada-A \\
\hline & 6 & Ibitinga & Carioca-80 & Certificada-A \\
\hline & 7 & Ibitinga & Carioca-80 & Certificada-A \\
\hline & 8 & Ibitinga & Carioca-80 & Certificada-A \\
\hline & 9 & Itápol is & Carioca-80 & Básica \\
\hline & 10 & Itāpolis & Carioca-80 & Certificada-A \\
\hline \multirow[t]{10}{*}{ 5. Jaboticabal } & 1 & Colômbia & Carioca-80 & Certificada- $A$ \\
\hline & 2 & Guaira & Carioca-80 & Bâsica \\
\hline & 3 & Guaira & Carioca-80 & Básica \\
\hline & 4 & Guaira & Carioca-80 & Básica \\
\hline & 5 & Guaira & Carioca-80 & Básica \\
\hline & 6 & Guaira & Carioca-80 & Básica \\
\hline & 7 & Guaíra & Carioca-80 & Certificada-A \\
\hline & 8 & Guaira & Carioca-80 & Certificada-A \\
\hline & 9 & Jaboticabal & Carioca-80 & Básica \\
\hline & 10 & Pitangueiras & Carioca-80 & Certificada-A \\
\hline
\end{tabular}




\begin{tabular}{|c|c|c|c|c|}
\hline Regiões & $\begin{array}{l}\text { NQ de } \\
\text { amos- } \\
\text { tras }\end{array}$ & Município & Cultivares & $\begin{array}{l}\text { Classes de } \\
\text { certificação }\end{array}$ \\
\hline \multirow[t]{2}{*}{ 6. Pirassununga } & 1 & Pirassununga & Carioca-80 & Básica \\
\hline & 2 & Pirassununga & Carioca-80 & Básica \\
\hline \multirow{10}{*}{$\begin{array}{l}\text { 7. Presidente } \\
\text { Prudente }\end{array}$} & 1 & Alvares Machado & Carioca-80 & Certificada-B \\
\hline & 2 & Caiabu & Carioca-80 & Certificada-B \\
\hline & 3 & Martinópolis & Carioca-80 & Certificada-B \\
\hline & 4 & Pirapozinho & Carioca-80 & Certificada-B \\
\hline & 5 & Pirapozinho & Carioca-80 & Certificada-B \\
\hline & 6 & Presidente Prudente & Carioca-80 & Certificada-B \\
\hline & 7 & $\begin{array}{l}\text { Presidente } \\
\text { Bemardes }\end{array}$ & Carioca-80 & Certificada-B \\
\hline & 8 & Taciba & Carioca-80 & Certificada-B \\
\hline & 9 & Taciba & Carioca-80 & Certificada-B \\
\hline & 10 & Tarabai & Carioca-80 & Certificada-B \\
\hline \multirow[t]{9}{*}{ 8. Ribeirão Preto } & 1 & Barrinha & Carioca-80 & Básica \\
\hline & 2 & Barrinha & Carioca-80 & Básica \\
\hline & 3 & Cravinhos & Carioca-80 & Certificada-A \\
\hline & 4 & Ituverava & Carioca-80 & Certificada-A \\
\hline & 5 & Ituverava & Carioca-80 & Certificada-A \\
\hline & 6 & Jardinópolis & Carioca-80 & Básica \\
\hline & 7 & Jardinópolis & Carioca-80 & Bāsica \\
\hline & 8 & Luiz Antōnio & Carioca-80 & Certificada-B \\
\hline & 9 & Luiz Antônio & Carioca-80 & Certificada-B \\
\hline
\end{tabular}




\begin{tabular}{lcccc}
\hline Regiões & $\begin{array}{c}\text { No de } \\
\text { amos- } \\
\text { tras }\end{array}$ & Municípios & Cultivares & $\begin{array}{c}\text { Classes de } \\
\text { certificação }\end{array}$ \\
\hline 8. Ribeirão Preto & 10 & Luiz Antônio & Carioca-80 & Certificada-A \\
& 11 & Ribeirão Preto & Carioca-80 & Certificada-A \\
\hline Total & 73 & 30 & 1 & 4 \\
\hline
\end{tabular}

\subsection{ANÁLISE DA SANIDADE DAS SEMENTES}

a. Método de papel de filtro comum: foram colocadas 200 sementes em placas de Petri de plástico $(100 \times 15 \mathrm{~mm})$, contendo três discos de papel de filtro previamente embebidos em água destilada, distribuindo-se 10 senentes por placa, de maneira equidistante uma da outra; as sementes foram incubadas a $22^{\circ} \mathrm{C}$ durante 8 dias, sob luz com radiação pró xima a ultra-violeta (NUV) em regime alternado de luz e escu ro de 12 horas. Em seguida, fez-se a deteção e identificação dos fungos ao microscópio estereoscópico e microscó pio composto quando necessārio (GRAHAM \& LUTTRELL, 1961; NATH et alii, 1970; BOOTH, 1971; ELLIS, 1971; BARNETT \& HUNTER, 1972; ELLIS, 1976; KULSHRESTHA et alii, 1976).

b. Método de papel de filtro com congelamento: nesse método que é apenas uma variação do anterior, 200 sementes foram distribuidas da mesma forma, em placas de Petri de plástico e incubadas nas mesmas condições que o 
item 3.2.a. por 24 horas; em seguida colocadas por mais 24 horas sob temperatura de $-18^{\circ} \mathrm{C}$ e novamente incubadas nas condições iniciais até completar oito dias. A iden tificação dos fungos também foi realizada ao microscópio estereoscópico e microscópio composto quando necessário, seguindo-se a mesma bibliografia utilizada para a avaliação do método de papel de filtro comum (item 3.2.a).

\subsection{ANÁlise FisiológicA DAS SEMENTES}

a. Germinação - o teste de germinação foi realizado em rolo de papel toalha ("Germ-test" tipo CEL 065) em germinador "Burrows", utilizando 200 (4 x 50) sementes, ou seja, 50 sementes por rolo. As condições de incubação foram de $30^{\circ} \mathrm{C}$ e umidade relativa de $100 \%$. A contagem foi realizada seguindo - se as normas do Ministério da Agricultura para análise de sementes, com uma primeira avaliação aos 4 dias e uma segunda avaliação aos 7 dias (BRASIL, 1976) •

b. Vigor - o teste de vigor empregado foi o envelhecimento a celerado, em câmara de envelhecimento "De Leo", com 100\% de umidade relativa e temperatura de $42^{\circ} \mathrm{C} .200$ ( $4 \times 50$ ) sementes foram colocadas em pequenos recipientes plásticos durante 72 horas nessas condições, seguindo-se imediata instalação do teste de germinação, conforme descrito no item (3.3.a). A avaliação foi realizada aos 4 dias após a in- 
cubação das sementes (MENTEN, 1978).

3.4. Precipitaç̃o das Regiões produtoras de SEMENTES DE FEIJOEIRO NO Estado de SÃo Paulo

Os dados de precipitação para as 13 regiões consideradas, referentes aos períodos de produção das sementes em estudo foram fornecidos pelo Departamento de Agua e Energia Elétrica de São Paulo (DAEE). Os valores correspondentes àquelas informações estão contidos na Tabela 1 .

\subsection{DeLineAMENTOS EXPER IMENTAIS}

\subsubsection{COMPARAČ̃̃ ENTRE MÉTOdOS DE SANIDADE}

Os métodos de papel de filtro e papel de filtro com congelamento, foram comparados através da análise de variância, pelo delineamento experimental inteiramente ao acaso. Para cada fungo de frequência mais acentuada nas amostras foi realizada uma análise.

As 133 amostras analisadas foram consideradas como repetições. Os dados apresentados em porcentagens, foram transformados segundo a expressão $\sqrt{\mathrm{x}+0,5}$, onde $\mathrm{x}$ repre senta a incidência ( $(\%)$ do fungo considerado. 


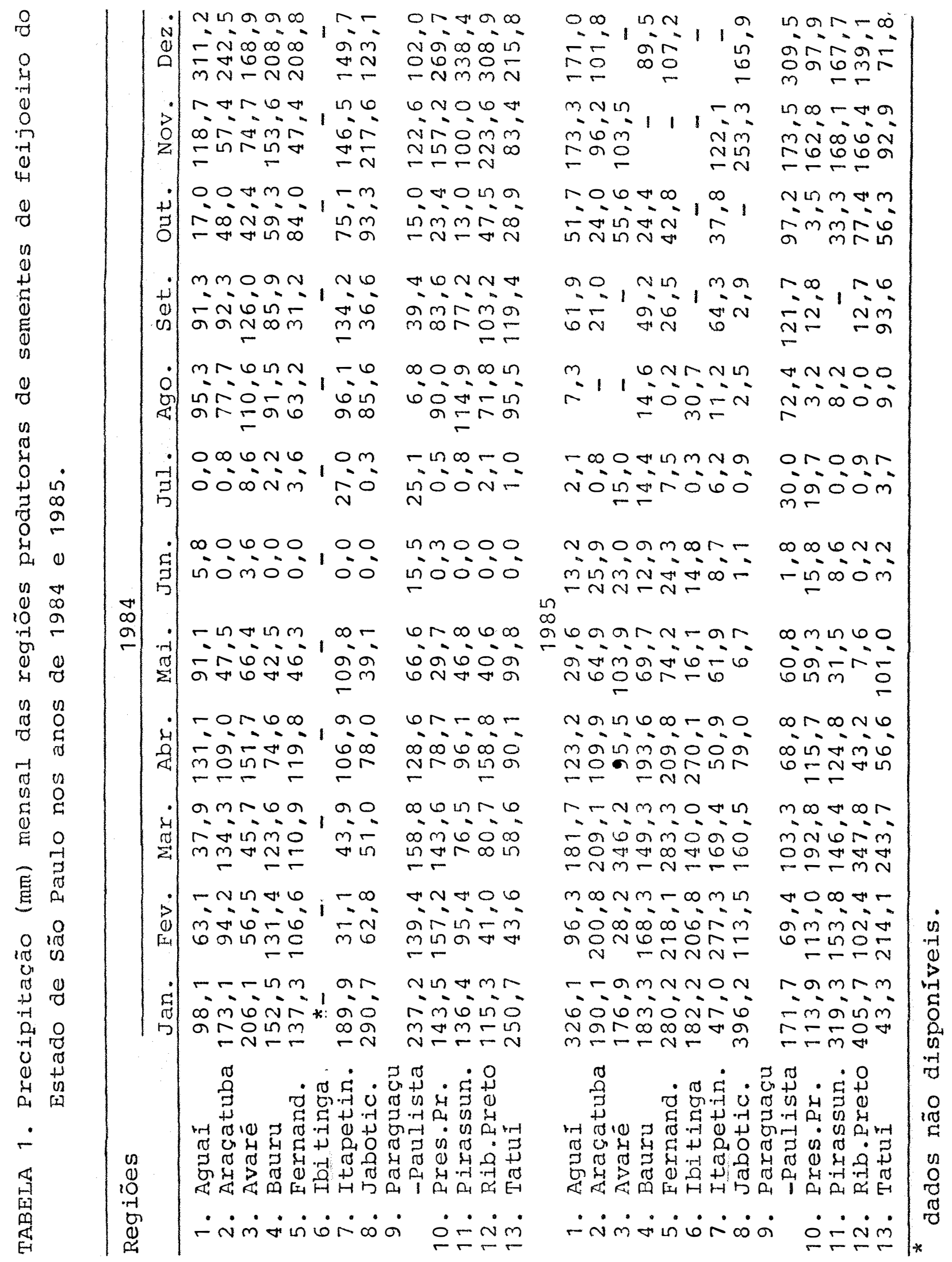


Uma vez estabelecido o melhor método de detec ção, todas as outras análises (itens 3.5 .3 a 3.5.6) foram feitas utilizando-se os resultados do melhor método encontrado. Devido ao baixo valor encontrado para as diferentes espécies de Fusarium, elas foram agrupadas, passando a ser consideradas, nas outras análises, como Fusarium spp., evitando repetições com valores nulos.

\subsubsection{CORRELACÃO DOS MÉTOdOS DE DETECCÃO}

Os métodos de detecção de fugnos, papel de filtro e papel de filgro com congelamento, foram correlacionados estatisticamente através de uma correlação simples ava liada através do teste $t$ e coeficiente de correlação (r); e pela equação da reta $(y=a x+b)$, além do erro padrão norma lizado (N.S.E.) numa segunda correlação linear (APPLE II, 1982), valores indicados na Tabela 6 .

Pela primeira análise os dados em porcentagem foram transformados em $\sqrt{x+0,5}$. A outra análise, além de indicar a existência ou não da correlação entre os dois métó dos de deteç̧ão através do N.S.E., como no teste $t$, forneceu a equação da reta, com o objetivo de possibilitar a substi- 
tuição de um método pelo outro, onde os valores de $\mathrm{x}$ referem -se à incidência (\%) do fundo no método de papel de filtro comum, e os valores de $y$, no método de papel de filtro com congelamento. Os dados desse teste de correlação não sofreram transformação.

\subsubsection{DISTRIBUIÇÃO GEOGRÁFICA DOS FUNGOS}

Com o objetivo de se estudar a distribuição dos fungos associados às sementes de feijoeiro no Estado de São Paulo, aplicou-se o teste de interações utilizado na estatística não paramétrica (SIEGEL, 1975).

As 13 regiões amostradas foram distribuidas numa sequência ordenada, a partir do extremo oeste do Estado de São Paulo. Para seguir o ordenamento, as regiões foram indicadas, como está representado na Figura 5, pela sede das regiões.

o teste de interações diz respeito à aleatoriedade da ocorrência temporal em um levantamento. Ele baseia-se na ordem dos eventos e fornece informações se existe 
.61.

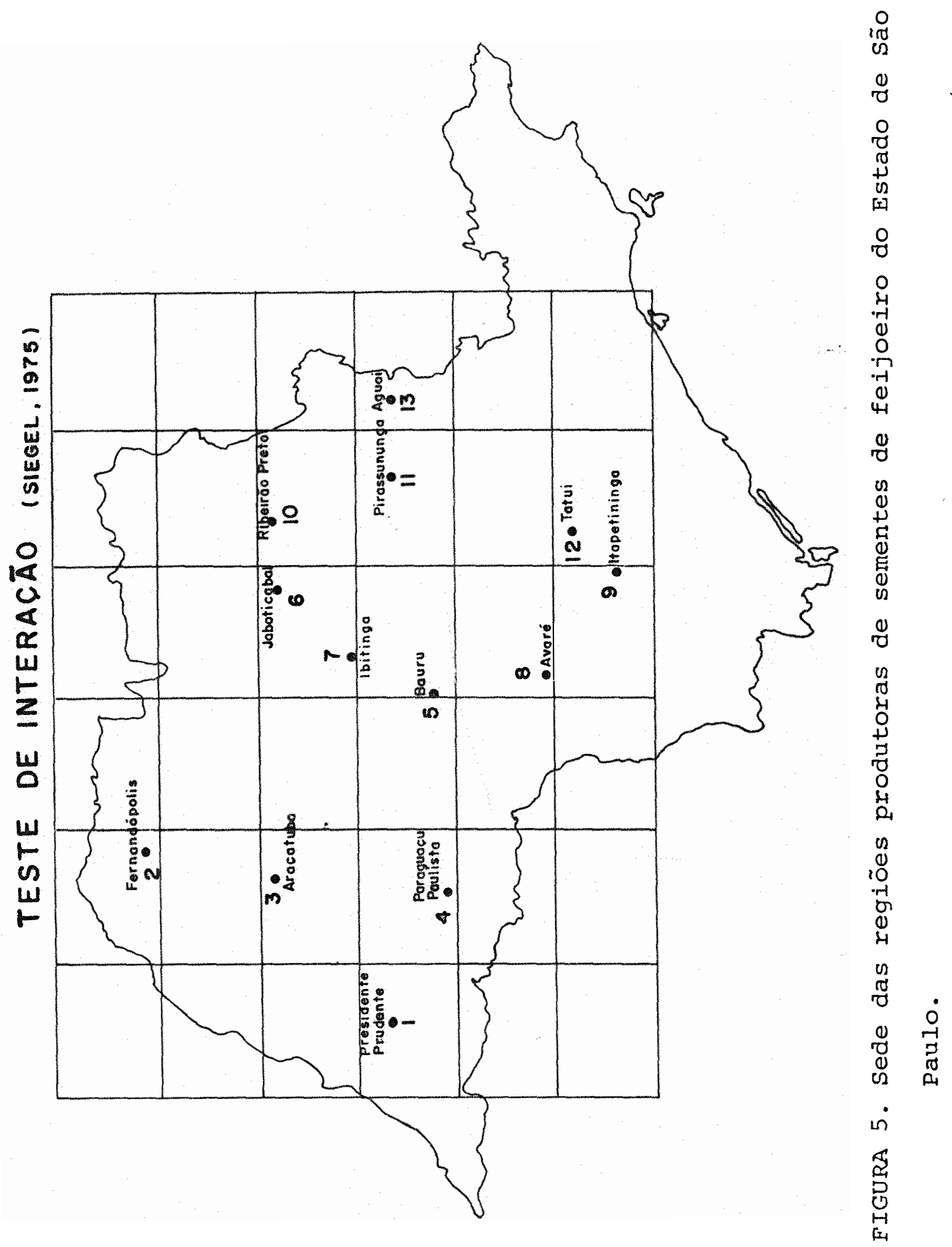


uma concentração estatisticamente significativa de um determinado fungo, num segmento da sequência ordenada.

3.5.4. EFEITO DO GENÓTIPO NA INCIDENCIA DE FUNGOS, GERMINAÇ̃O E ENVELHECIMENTO ACELERADO DAS SEMENTES DE FEIJOEIRO

O efeito das cultivares Carioca e Carioca-80 sobre a incidência de cada fungo estudado, sobre a germinação e o envelhecimento acelerado, foi analisado estatisticamente através do delienamento inteiramente casualizado. As repetições referem-se às amostras analisadas, sendo que 30 pertencem à cultivar Carioca e 103 à cultivar Carioca-80. Os dados em porcentagem foram transformados segundo a expressão $\sqrt{x+0,5}$.

3.5.5. EFEITO DE REgIÕES E ÉPOCAS DE PRODUÇÃO NA INCIDENCIA DE FUNGOS, GERMINACÃO E ENVELHECIMENTO ACELERADO DAS SEMENTES DE FEIJOEIRO

O efeito de regiões e épocas foi avaliado estatisticamente pela análise de variância simples inteiramente ao acaso, com número variável de repetição, referentes ao núme- 
ro de amostras de cada local estudado. Os dados em porcenta gem foram transformados segundo a expressão $\sqrt{\mathrm{x}+0,5}$. Pelo fato dos resultados serem bastante irregulares, não foi possível determinar estatisticamente o efeito de época de produ ção na incidência de fungos, e nem estabelecer uma interação entre região e época de produção, através de um fatorial, on de nem sempre os niveis de fatores se repetiriam.

\subsubsection{CORRELAÇ̃̃O ENTRE SANIDADE, GERMINACÃO E ENVE- LHECIMENTO ACELERADO DAS SEMENTES \\ O efeito dos microrganismos estudados sobre a} germinação e o envelhecimento acelerado das sementes, e acor relação entre a germinação e o envelhecimento acelerado das sementes foram determinados através de uma regressão linear, segundo $o$ teste $t$, a nivel de 5\% de probabilidade, utilizando-se a média, em porcentagem, dos valores encontrados para cada região amostrada. 


\section{RESULTADOS}

\subsection{Fungos detectados nas sementes de fÉIJOEIRo através DOS MÉTODOS DE PAPEL DE FILTRO COMUM E PAPEL DE FIL TRO COM CONGELAMENTO}

Dentre as 133 amostras avaliadas, detectaram-se 32 fungos diferentes, através dos métodos de papel de filtro comum e papel de filtro com congelamento, a saber: A $\underline{\ell}$ ternaria spp., A. tenuis, Aspergillus spp., Botryodiplodia theobromae, Cephalosporium sp., Cladosporium sp., Colletotri chum dematium, C. lindemuthianum, Curvularia sp., Drechslera sp., Epicoccum sp., Fusarium equiseti, F. moniliforme, F. oxysporum, F. semitectum, Fusarium spp., Gonatobotrys sp., Leptosphaerulina sp., Macrophomina phaseolina, Neurospora sp., Nigrospora sp., Paecylomices sp., Penicillium spp., Pestalotia sp., Phoma sp., Phomopsis sp., Pithomyces sp., Rhizoctonia solani, Rhizopus sp., Stemphylium sp., Trichoderma 
sp. e Trichotecium sp.

Desses, os mais frequentes foram A. tenuis, Aspergillus spp., Cladosporium sp. e Penicillium spp.

A Tabela 2 mostra a incidência média nas 133 amostras, dos fungos mais frequentes ou considerados mais im portantes, detectados pelos métodos de papel de filtro comum (S/C) e papel de filtro com congelamento (C/C).

Os fungos B. theobronal, C. lindemuthianum e M. phaseolina foram relacionados separadamente, por incidirem apenas em quantidades traços na média do total de amostras avaliadas (Tabelas 3,4 e 5 ).

\subsubsection{INCIDENCIA DE Alternaria SPP.}

A incidência de Alternaria spp. nas sementes de feijoeiro variou de 0 a 7,0\%. Das 133 amostras avaliadas, apenas 33,1\% apresentaram o microrganismo. O teste de papel de filtro com congelamento recuperou em média maior porcentagem de Alternaria spp. $(0,40 \%)$ enquanto o teste de papel de filtro sem congelamento recuperou somente $0,10 \%$ (Ta bela 2) . 
.66.

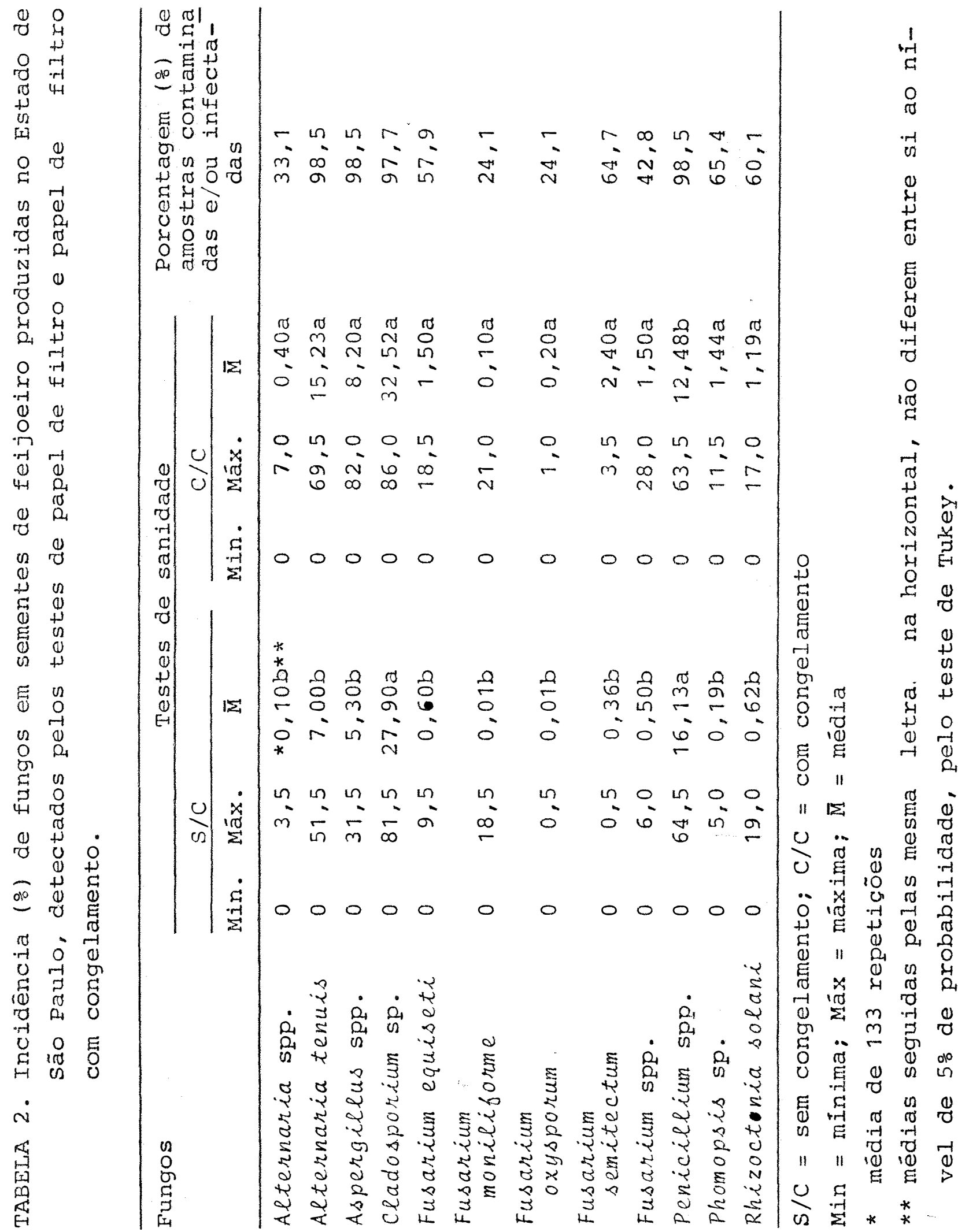




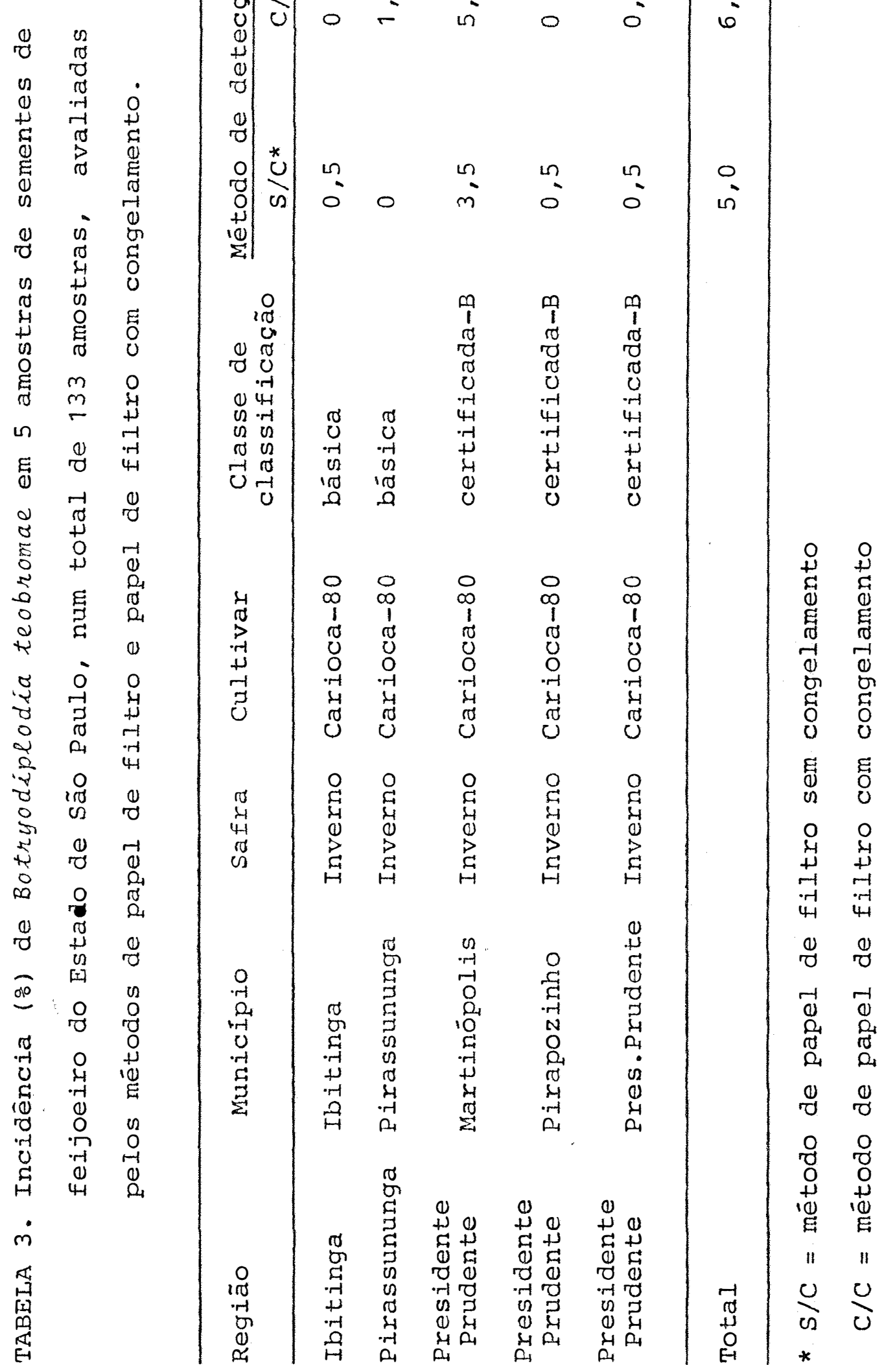


.68.

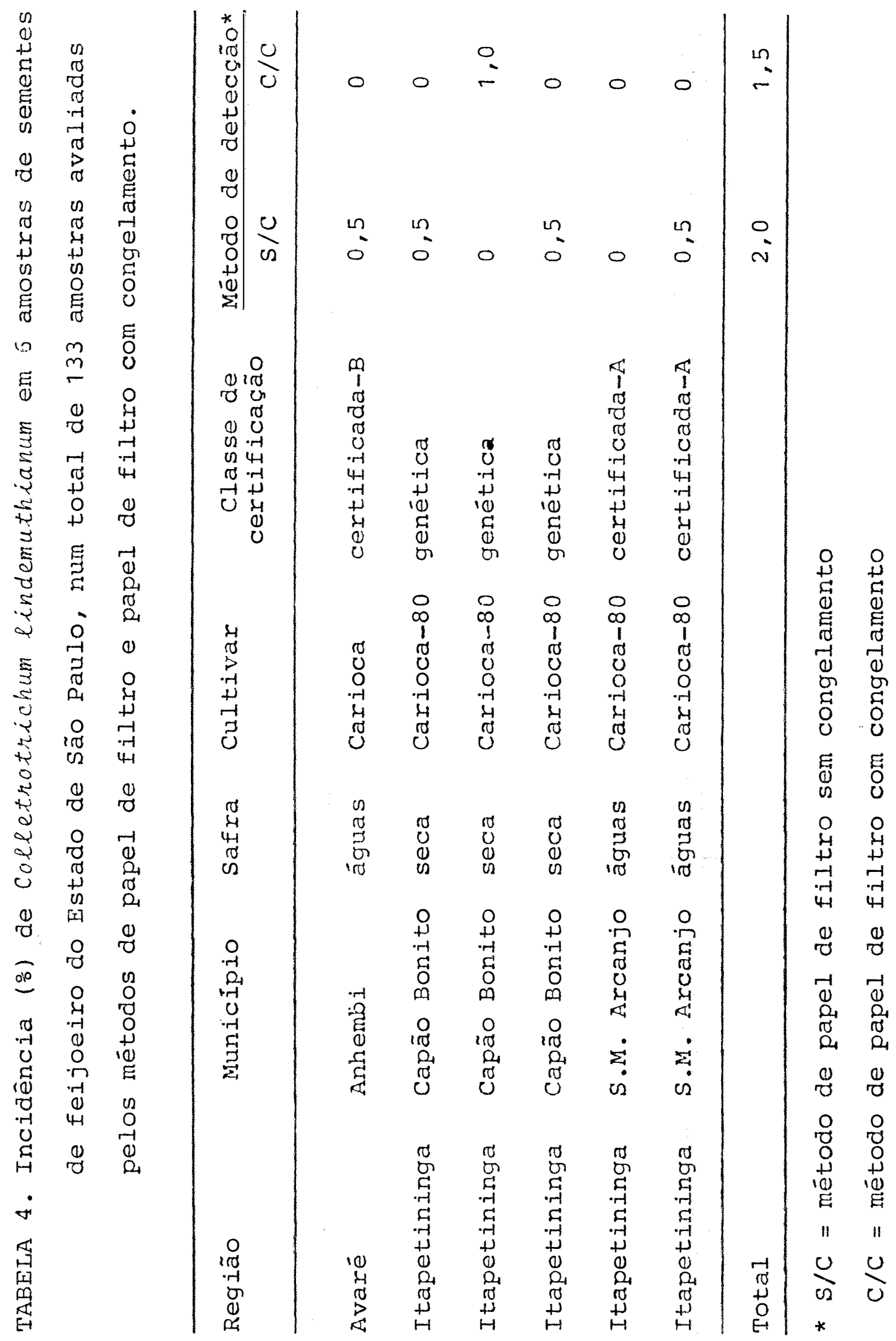




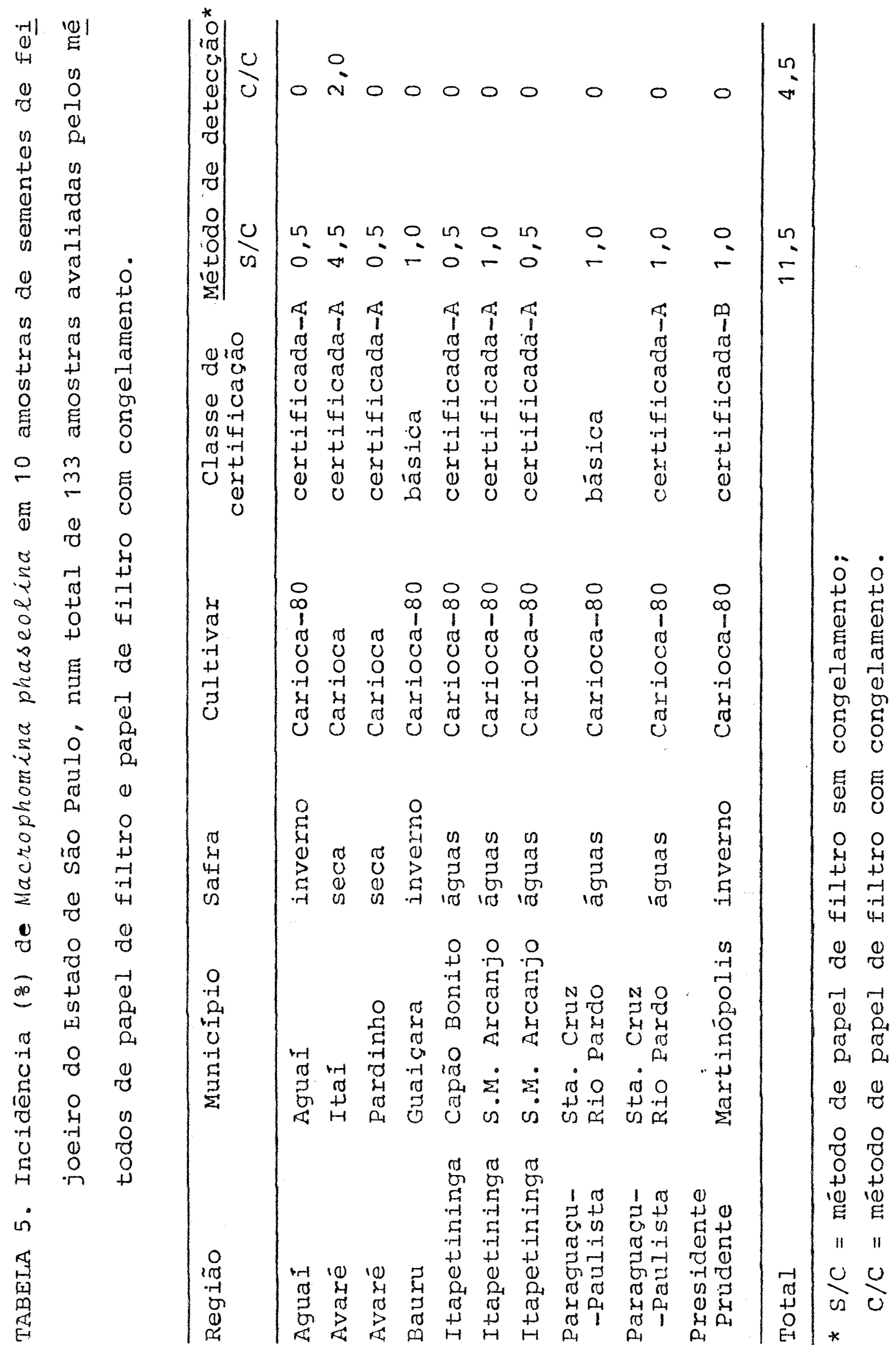


4.1.2. INCIDENCIA DE Alternaria tenuis

A incidência de Alternaria tenuis nas sementes de feijoeiro variou de 0 a $69,5 \%$. Das 133 amostras avaliadas, somente $1,5 \%$ não apresentaram o microrganismo. O teste de papel de filtro com congelamento recuperou em média maior porcentagem de A. tenuis $(15,23 \%)$, enquanto o teste de papel de filtro sem congelamento recuperou 7,0\% (Tabela 2).

4.1.3. INCIDENCIA DE Aspergillus spp.

$\lambda$ incicência de Aspergillus spp. nas sementes de feijoeiro, variou de 0 a $82 \%$. Apenas $1,5 \%$ das amostras não apresentaram $\circ$ fungo. O teste de papel de filtro com congelamento permitiu detectar em mécia maior porcentagem de Aspergillus spp. $(8,20 \%)$, enquanto o outro método detectou $5,30 \%$ (Tabela 2).

\subsubsection{INCIDENCIA DE Cladosporium sp.}

Cladosporium sp. foi o fungo de maior incidên cia nas sementes de feijoeiro, variando de 0 a 86,0\%. Cerca de $2 \%$ das amostras não apresentaram o microrganismo. Não hou ve diferença entre os testes utilizados com 27,90 e 32,52\% para $\circ$ de papel de filtro e papel de filtro com congelamento (Tabela 2), respectivamente. 


\subsubsection{INCIDENCIA DE Fusarium equiseti}

A incicência de Fusarium equiseti nas sementes de feijoeiro variou de 0 a 18,5\%. Entre as amostras analisadas, mais da metade $(57,9 \%)$ apresentaram 0 fungo. O teste que de tectou maior média de $F$. equiseti foi o papel de filtro com congelamento $(1,50 \%)$, enquanto o outro procedimento detectou apenas $0,60 \%$ (Tabela 2).

4.1.6. INCIDENCIA DE Fusarium moniliforme

A incidência de Fusarium moniliforme nas sementes de feijoeiro variou de 0 a $21,0 \%$. Além do baixo valor de associação com a semente, poucas amostras apresentaram o fungo $(24,1 \%)$. O teste de papel de filtro com congela mento detectou em média maior porcentagem de $F$. moniliforme $(0,10 \%)$ enquanto o outro procedimento detectou apenas $0,01 \%$ (Tabela 2).

\subsubsection{INCIDENCIA DE Fusarium oxysporum}

A incidência de Fusarium oxysporum encontrada nas sementes de feijoeiro variou de 0 a 1,0\%. Apenas 24,1\% das amostras mostraram a associação do fungo com a semente. o procedimento utilizando o congelamento permitiu maior recu 
peração de $F$. oxysporum $(0,20 \%)$, ao passo que o teste sem congelamento recuperou $0,01 \%$ (Tabela 2).

\subsubsection{INCIDENCIA DE Fusarium semitectum}

Entre as espécies de Fusarium associadas às sementes de feijoeiro, F. semitectum ocorreu em maior número de amostras $(64,7 \%)$, variando de 0 a $3,5 \%$. O teste de papel de filtro com congelamento mostrou maior incidência do fungo $(2,4.0 \%)$, enquanto que $\circ$ teste de papel de filtro sem congela mento $0,36 \%$ apenas (Tabela 2).

4.1.9. INCIDENCIA DE Fusarium spp.

A incidência de Fusarium spp. nas sementes de feijoeiro variou de 0 a $28,0 \%$. Das amostras analisadas, menos da metade $(42,8 \%)$, apresentaram $\circ$ fungo. Houve diferen ça entre os dois testes para deteç̧ão, sendo que em mëdia, o teste de papel de filtro com congelamento permitiu maior recuperação de Fusarium spp. $(1,5 \%)$, enquanto o outro teste recuperou $0,5 \%$ somente (Tabela 2 ). 
4.1.10. INCIDENCIA DE Penicillium spp.

A incidência de Penicillium spp. nas sementes de feijoeiro foi frequente, com variação de 0 até $64,5 \%$ e somente $1,5 \%$ das amostras não mostraram a associação com o fungo. O teste de papel de filtro que não utilizou o congelamento, recuperou em média maior porcentagem $(16,13 \%)$, enquanto o uso do congelamento diminuiu a recuperação para $12,48 \%$ (Tabela 2).

4.1.11. INCIDENCIA DE Phomopsis sp.

A incidência de Phomopsis $\mathrm{sp}$. nas sementes de feijoeiro variou de 0 a $11,5 \%$. Grande parte das amostras avaliadas apresentaram o fungo $(65,4 \%)$. O teste utilizando o congelamento detectou maior porcentagem de Phomopsis sp. $(1,44 \%)$ e o teste sem uso do congelamento detectou apenas $0,19 \%$ (Tabela 2) .

\subsubsection{INCIDENCIA DE Rhizoctonia solani}

A incidência desse patógeno nas sementes de feijceiro variou de 0 a 19,0\%. Grande parte das amostras apresentou o fungo $(60,1 \%)$. O teste de papel de filtro com congelamento detectou maior porcentagem de $R$. solani $(1,19 \%)$, 
ao passo que o primeiro método detectou basicamente a metade (Tabela 2).

\subsubsection{INCIDENCIA DE Botryodiplodia theobromae}

Somente 5 amostras $(3,8 \%)$ apresentaram $\circ$ fungo, onde apenas aquela pertencente à região de Presidente Prudente, produzida em Martinópolis, apresentou maior incidência $(3,5 \%$ e $5,0 \%)$, através dos métodos de papel de filtro sem e com congelamento, respectivamente (Tabela 3 ).

4.1.14. INCIDENCIA DE Colletotrichum lindemuthianum

O patógeno foi detectado em apenas 6 amostras $(4,5 \%)$, incidindo de 0 a $1,0 \%$ (Tabela 4).

4.1.15. INCIDENCIA DE Macrophomina phaseolina

O patógeno ocorreu em 10 amostras $(7,5 \%)$, com a incidência nas sementes variando de 0 a $4,5 \%$ (Tabela 5). 
4.2. Correlaç̃̃o dos métodos de detecç̃̃o

Os resultados da correlação linear estabelecí da entre os dois métodos de deteç̧ão dos fungos, estão indicados na Tabela 6 .

\subsection{TESTE DE INTERAÇ̃̃ES}

O teste de interaçōes que permitiu indicar a concentraçāo ou aleatoriedade na ocorrência dos fungos estudados, revelou os seguintes resultados: houve uma certa tendência de A. tenuis em se concentrar nas regiões Avaré, Itapetininga e Tatuí; Cladosporium sp. em Presidente prudente, Fernandōpolis e Aguaí; além de $R$. solani em Jaboticabal, Ib tinga, Avaré e Itapetininga, onde o nível mínimo de significāncia (n.m.s.) encontrado foi de 0,095 para os três casos.

Os demais fungos (Alternaria spp., Aspergillus spp., Fusarium spp., Penicillium sp. e Phomopsis sp.) mostraram uma distribuição totalmente aleatória no Estado de São Paulo, a partir das regiões amostradas, com valores do n.m.s. de 0,$133 ; 0,540 ; 0,800 ; 0,700$ e 0,333 , respectivamente. 
TABELA 6. Correlação dos métodos de deteç̧ão de fungos, papel de filtro comum e papel de filtro com congelamento, em sementes de feijoeiro produzidas no Esta do de São Paulo.

\begin{tabular}{ll}
\hline Fungos & $\begin{array}{c}\text { Coeficiente } \\
\text { de } \\
\text { correlação } \\
(r)\end{array}$
\end{tabular}
(r)

Alternaria spp.

A. tenuis

Aspergillus spp.

cladosporium sp.

Fusarium equiseti

F. moniliforme

F. oxysporum

F. semitectum

Fusarium spp.

Penicillium spp.

Phomopsis sp.

Rhizoctonia solani

$$
\begin{array}{lll}
+0,62 * & * y=1,57 x+0,20 & 0,76 \\
+0,87 * & y=1,05 x+8,40 & 0,57 \\
+0,78 * & y=1,14 x+2,22 & 0,69 \\
+0,96 * & y=1,02 x+3,80 & 0,30 \\
+0,65 * & y=1,36 x+0,78 & 0,51 \\
+0,01 & y=0,26 x+0,15 & 1,00 \\
+0,15 & y=0,87 x+0,23 & 1,00 \\
+0,28 * & y=2,05 x+1,63 & 0,84 \\
+0,67 * & y=1,97 x+0,51 & 0,47 \\
+0,75 * & y=0,56 x+3,23 & 0,79 \\
+0,33 * & y=1,54 x+1,24 & 0,94 \\
+0,73 * & y=0,94 x+0,60 & 0,55
\end{array}
$$

* valores significativos a nivel de 5\% de probabilidade, se gundo tabela para coeficiente de correlação $(x)$ e tabela $t$ consultadas.

** $y=a x+b$, onde $x=$ incidência $(\%)$ do fungo obtida pelo método de papel de filtro comum e $y=$ incidência (\%) do fungo obtida pelo método de papel de filtro com congelamento.

*** NSE $=$ erro padrão normalizado. 
4.4. INCIDENCIA DE FUNGOS, GERMINACÃO E ENVELHECIMENTO ACELERADO DAS SEMENTES DAS CULTIVARES CARIOCA E CARIO CA -80

O efeito do genótipo das cultivares Carioca e Carioca-80 está demonstrado na Tabela 7 , onde se verifica maior incidência na cultivar Carioca para a maioria dos fungos estudados, com exceção de Cladosporium sp. e Phomopsis sp. que ocorreram em maior porcentagem nas sementes da culti var Carioca-80. Uma diferença marcante ocorreu com relação a Fusarium spp., ou seja, aproximadamente $16 \%$ na cultivar Ca rioca, e quase 3 \% somente na cultivar Carioca-80. 
TABELA 7. Incidência (\%) de fungos nas sementes de feijoeiro das cultivares Carioca e Carioca-80.

\begin{tabular}{lcc}
\hline Fungos & Carioca & Carioca-80 \\
\hline Alternaria spp. & $0,27 \mathrm{a}^{*}$ & $0,44 \mathrm{a}$ \\
Alternaria tenuis & $26,32 \mathrm{a}$ & $12,64 \mathrm{~b}$ \\
Aspergillus spp. & $13,62 \mathrm{a}$ & $6,80 \mathrm{~b}$ \\
Cladosporium sp. & $14,55 \mathrm{~b}$ & $38,35 \mathrm{a}$ \\
Fusarium spp. & $15,97 \mathrm{a}$ & $2,85 \mathrm{~b}$ \\
Penicillium spp. & $11,40 \mathrm{a}$ & $12,80 \mathrm{a}$ \\
Phomopsis sp. & $0,83 \mathrm{~b}$ & $1,65 \mathrm{a}$ \\
Rhizoctonia solani & $1,63 \mathrm{a}$ & $1,06 \mathrm{~b}$ \\
\hline
\end{tabular}

* médias seguidas pelas mesmas letras, na horizontal, não di ferem estatisticamente entre si, ao nivel de 5\% de probabi lidade pelo teste de Tukey.

O efeito do genótipo das duas cultivares sobre a germinação e o envelhecimento acelerado está apresenta do na Tabela 8. 
TABELA 8. Germinação (\%) e envelhecimento acelerado (\%) de sementes de feijoeiro das cultivares Carioca e Carioca-80.

\begin{tabular}{lcc} 
& Carioca & Carioca-80 \\
\hline Germinação & $74,0 a^{*}$ & $76,0 \mathrm{a}$ \\
Envelhecimento acelerado & $50,0 \mathrm{~b}$ & $66,0 \mathrm{a}$ \\
\hline
\end{tabular}

*médias seguidas pelas mesmas letras, na horizontal, não diferem entre si pelo teste de Tukey ao nivel de 5\% de probabilidade.

4.5. EFEITO DE REgiões NA INCIDENCIA DE FUNGOS ASSOCIADOS ÀS SEMENTES DE FEIJOEIRO DENTRO DE CADA ÉPOCA DE PRODUÇÃO

As Tabelas de 9 a 16 demonstram o efeito de regiões na incidência de cada fungo considerado, dentro da ëpoca da seca, das águas e de inverno.

4.5.1. EFEITO DE REgIÕES NA INCIDENCIA DE Alternaria spp.

Os resultados (Tabela 9) demonstraram que não houve efeito de locais para o fungo, em nenhuma das três épo cas estudadas. 
TABELA 9. Efeito de regiões na incidência (\%) de Alternaria spp. em sementes de feijoeiro do Estado de são Pau 1o, dentro de cada época.

\begin{tabular}{|c|c|c|c|}
\hline Regiões & $\operatorname{seca}-84$ & Aguas $84 / 85$ & Inverno-85 \\
\hline 1. Aguai & - & $0,6 a$ & $0,8 a$ \\
\hline 2. Araçatuba & $0,0 a *$ & - & - \\
\hline 3. Avaré & $1,0 \mathrm{a}$ & $0,2 a$ & - \\
\hline 4. Bauru & $0,0 \mathrm{a}$ & - & $0,2 \mathrm{a}$ \\
\hline 5. Fernandópolis & $0,7 a$ & - & $0,0 \mathrm{a}$ \\
\hline 6. Ibitinga & - & - & $0,1 \mathrm{a}$ \\
\hline 7. Itapetininga & $1,0 a$ & $2,1 \mathrm{a}$ & - \\
\hline 8. Jaboticabal & $0,9 a$ & - & $0,0 \mathrm{a}$ \\
\hline 9. P. Paulista & - & $0,3 a$ & - \\
\hline 10. Pirassununga & - & - & $0,0 \mathrm{a}$ \\
\hline 11. Pres. Prudente & - & - & $0,0 \mathrm{a}$ \\
\hline 12. Rib. Preto & - & - & $0,04 a$ \\
\hline 13. Tatui & $1,0 \mathrm{a}$ & $0,3 a$ & - \\
\hline Médias & 0,66 & 0,70 & 0,14 \\
\hline
\end{tabular}

* Médias seguidas pela mesma letra, na vertical, não dife riram entre si, pelo teste de Tukey, ao nivel de $5 \%$ de pro babilidade. 
TABELA 10. Efeito de regiões na incidência de Alternaria tenuis em sementes de feijoeiro do Estado de são Paulo, dentro de cada época.

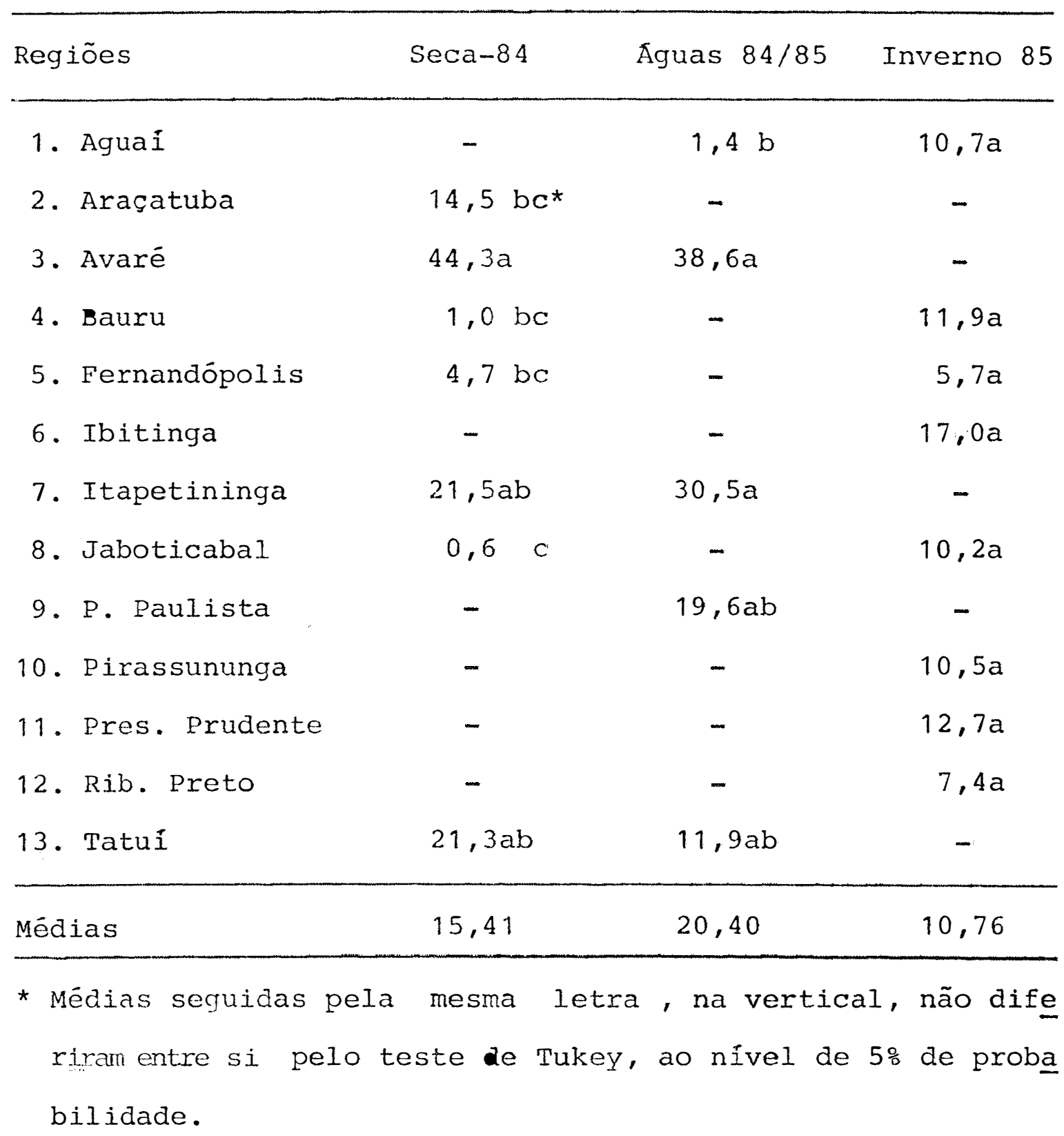


TABELA 11. Efeito de regiões na incidência (\%) de Aspergil: lus spp. em sementes de feijoeiro do Estado de São Paulo, dentro de cada época.

\begin{tabular}{|c|c|c|c|}
\hline Regiões & Seca-84 & Åguas $84 / 85$ & Inverno 85 \\
\hline 1. Aguai & - & $2,4 \mathrm{~b}$ & $2,8 \mathrm{a}$ \\
\hline 2. Araçatuba & $1,6 \mathrm{ab} *$ & - & - \\
\hline 3. Avaré & $13,9 \mathrm{a}$ & $1,9 \mathrm{~b}$ & - \\
\hline 4. Bauru & $1,5 a b$ & - & $6,2 a$ \\
\hline 5. Fernandöpolis & $6,5 a b$ & - & $12,6 \mathrm{a}$ \\
\hline 6. Ibitinga & - & - & $6,7 a$ \\
\hline 7. Itapetininga & $6,7 \mathrm{ab}$ & $4,3 \mathrm{~b}$ & - \\
\hline 8. Jaboticabal & $1,0 \mathrm{~b}$ & - & $5,2 \mathrm{a}$ \\
\hline 9. P. Paulista & - & $15,9 a$ & - \\
\hline 10. Pirassununga & - & - & $7,2 \mathrm{a}$ \\
\hline 11. Pres. Prudente & - & - & $5,5 a$ \\
\hline 12. Rib. Preto & - & - & $10,9 \mathrm{a}$ \\
\hline 13. Tatui & $20,9 a$ & $25,4 \mathrm{a}$ & - \\
\hline Médias & 7,44 & 9,98 & 7,14 \\
\hline
\end{tabular}

* Médias seguidas pela mesma letra, na vertical, não dife riram entre si, pelo teste de Tukey, ao nivel de $5 \%$ de pro babilidade. 
TABELA 12. Efeito de regiões na incidência (\%) de cladosporium $\mathrm{sp}$. em sementes de feijoeiro do Estado de São Paulo, dentro de cada época.

\begin{tabular}{|c|c|c|c|}
\hline Regiões & Seca-84 & Aguas $84 / 85$ & Inverno-85 \\
\hline 1. Aguai & - & $5,8 \mathrm{ab}$ & $60,1 \mathrm{a}$ \\
\hline 2. Araçatuba & $42,5 a b$ * & - & - \\
\hline 3. Avaré & $9,3 \quad c$ & $2,7 \mathrm{~b}$ & - \\
\hline 4. Bauru & $10,0 \mathrm{bc}$ & - & $50,9 a$ \\
\hline 5. Fernandópolis & $68,5 a$ & - & $67,3 a$ \\
\hline 6. Ibitinga & - & - & $49,9 a$ \\
\hline 7. Itapetininga & $14,6 \mathrm{bc}$ & $1,1 \mathrm{~b}$ & - \\
\hline 8. Jaboticabal & $3,2 \quad \mathrm{c}$ & - & $39,3 a$ \\
\hline 9. P. Paulista & - & $15,7 a$ & - \\
\hline 10. Pirassununga & - & - & $40,5 a$ \\
\hline 11. Pres. Prudente & - & - & $36,4 a$ \\
\hline 12. Rib. Preto & - & - & $48,7 a$ \\
\hline 13. Tatui & $9,7 \quad \mathrm{c}$ & $4,7 \mathrm{~b}$ & - \\
\hline Médias & 22,54 & 6,00 & 49,14 \\
\hline
\end{tabular}

* médias seguidas pela mesma letra, na vertical, não dife riram entre si, pelo teste de Tukey, ao nível de 5\% de pro babilidade. 
TABELA 13. Efeito de regiões na incidência (\%) de Fusarium spp. em sementes de feijoeiro do Estado de são Paulo, dentro de cada época.

\begin{tabular}{|c|c|c|c|}
\hline Regiões & $\operatorname{seca}-84$ & Āguas-84/85 & Inverno-85 \\
\hline 1. Aguai & - & $0,6 \mathrm{~b}$ & $4,8 a$ \\
\hline 2. Araçatuba & $3,0 \mathrm{bc} *$ & - & - \\
\hline 3. Avarē & $36,6 a$ & $7,7 a$ & - \\
\hline 4. Bauru & $2,0 \mathrm{bc}$ & - & $1,8 \mathrm{a}$ \\
\hline 5. Fernandópolis & $28,5 \mathrm{ab}$ & - & $2,5 a$ \\
\hline 6. Ibitinga & - & - & $0,9 a$ \\
\hline 7. Itapetininga & $3,1 \mathrm{bc}$ & $5,1 \mathrm{ab}$ & - \\
\hline 8. Jaboticabal & $7,5 \mathrm{bc}$ & - & $1,3 a$ \\
\hline 9. Par. Paulista & - & $5,2 \mathrm{ab}$ & - \\
\hline 10. Pirassununga & - & - & $1,0 \mathrm{a}$ \\
\hline 11. Pres. Prudente & - & - & $3,3 a$ \\
\hline 12. Rib. Preto & - & - & $1,3 a$ \\
\hline 13. Tatui & $7,5 \mathrm{bc}$ & $3,7 \mathrm{ab}$ & - \\
\hline Médias & 12,70 & 4,46 & 2,11 \\
\hline
\end{tabular}

* Médias seguidaspela mesma letra, na vertical, não diferiram entre si, pelo teste de Tukey, ao nível de 5\% de proba bilidade. 
TABELA 14. Efeito de regiões na incidência (\%) de Penicillium spp. em sementes de feijoeiro do Estado de São Paulo, dentro de cada época.

\begin{tabular}{|c|c|c|c|}
\hline Regiões & Seca-84 & Aguas $84 / 85$ & Inverno-85 \\
\hline 1. Aguai & - & $19,1 \mathrm{bc}$ & $4,0 \mathrm{~b}$ \\
\hline 2. Araçatuba & $2,7 b *$ & - & - \\
\hline 3. Avaré & $6,6 \mathrm{ab}$ & 2,4 & - \\
\hline 4. Bauru & $5,5 a b$ & - & $13,5 \mathrm{ab}$ \\
\hline 5. Fernandópolis & $4,0 \mathrm{ab}$ & - & $11,8 \mathrm{ab}$ \\
\hline 6. Ibitinga & - & - & $5,4 \mathrm{~b}$ \\
\hline 7. Itapetininga & $8,9 a b$ & $6,5 \quad c d$ & - \\
\hline 8. Jaboticabal & $5,9 a b$ & - & $8,9 a b$ \\
\hline 9. Par. Paulista & - & $38,6 a$ & - \\
\hline 10. Pirassununga & - & - & $19,2 a b$ \\
\hline 11. Pres. Prudente & - & - & $24,8 a$ \\
\hline 12. Rib. Preto & - & - & $17,1 \mathrm{ab}$ \\
\hline 13. Tatuí & $22,9 a$ & $19,5 \mathrm{ab}$ & - \\
\hline Médias & 8,07 & 17,22 & 13,09 \\
\hline
\end{tabular}

* Médias seguidas pela mesma letra, na vertical, não diferiram entre si, pelo teste de Tukey, ao nivel de 5\% de proba bilidade. 
TABELA 15. Efeito de regiões na incidência (\%) de Phomopsis sp. em sementes de feijoeiro do Estado de São Pau 1o, dentro de cada época.

\begin{tabular}{lccc}
\hline Regiões & Seca-84 & Aguas $84 / 85$ & Inverno-85 \\
\hline 1. Aguai & - & $0,4 \mathrm{~b}$ & $1,9 \mathrm{ab}$ \\
2. Araçatuba & $0,2 \mathrm{a}$ & - & - \\
3. Avaré & $0,8 \mathrm{a}$ & $0,5 \mathrm{~b}$ & - \\
4. Bauru & $4,5 \mathrm{a}$ & - & $3,7 \mathrm{a}$ \\
5. Fernandópolis & $2,5 \mathrm{a}$ & - & $1,4 \mathrm{ab}$ \\
6. Ibitinga & - & - & $1,4 \mathrm{ab}$ \\
7. Itapetininga & $0,3 \mathrm{a}$ & $0,1 \mathrm{~b}$ & - \\
8. Jaboticabal & $1,1 \mathrm{a}$ & - & $0,9 \mathrm{~b}$ \\
9. Par. Paulista & - & $4,1 \mathrm{a}$ & - \\
10. Pirassununga & - & - & $2,5 \mathrm{ab}$ \\
11. Pres. Prudente & - & - & $0,5 \mathrm{~b}$ \\
12. Rib. Preto & - & - & $2,2 \mathrm{ab}$ \\
13. Tatui & $1,5 \mathrm{a}$ & $0,5 \mathrm{~b}$ & - \\
\hline Médias & 1,56 & 1,12 & 1,81 \\
\hline
\end{tabular}

* médias seguidas pela mesma letra, na vertical, não diferiram entre si, pelo teste de Tukey, ao nível de 5\% de proba bilidade. 
TABELA 16. Efeito de regiões na incidência (q) de Rhizoctonia solani em sementes de feijoeiro do Estado de São Paulo, dentro de cada época.

\begin{tabular}{|c|c|c|c|}
\hline Regiões & Seca-84 & Águas 84/85 & Inverno 85 \\
\hline 1. Aguai & - & $1,2 \mathrm{a}$ & $0,2 \mathrm{a}$ \\
\hline 2. Araçatuba & $1,9 a *$ & - & - \\
\hline 3. Avaré & $3,3 \mathrm{a}$ & $0,5 a$ & - \\
\hline 4. Bauru & $0,0 \mathrm{a}$ & - & $0,6 a$ \\
\hline 5. Fernandópolis & $0,5 a$ & - & $0,6 a$ \\
\hline 6. Ibitinga & - & - & $0,7 \mathrm{a}$ \\
\hline 7. Itapetininga & $0,8 a$ & $2,9 a$ & - \\
\hline 8. Jaboticabal & $9,6 a$ & - & $0,6 a$ \\
\hline 9. Par.Paulista & - & $0,1 \mathrm{a}$ & - \\
\hline 10. Pirassununga & - & - & $0,0 \mathrm{a}$ \\
\hline 11. Pres.Prudente & - & - & $0,2 \mathrm{a}$ \\
\hline 12. Rib. Preto & - & - & $0,5 \mathrm{a}$ \\
\hline 13. Tatui & $1,2 \mathrm{a}$ & $0,8 \mathrm{a}$ & - \\
\hline Médias & 2,47 & 1,10 & 0,42 \\
\hline
\end{tabular}

* Medias seguidas pela mesma letra, na vertical, não diferiram entre si, pelo teste de Tukey, ao nivel de 5\% de proba bilidade. 
4.5.2. EFEITO DE REGIÃO NA INCIDENCIA DE Alternaria tenuis

Os resultados (Tabela 10) demonstraram que houve efeito de locais na incidência de A. tenuis dentro da época da seca e das águas, não diferindo entre os locais na época de inverno.

A melhor região produtora, na época da seca, com menor frequência do fungo nas sementes foi Jaboticabal , seguida de Bauru, Fernandópolis e Araçatuba, e a região com maior frequência foi Avaré. Na época das águas a melhor região foi Aguaí e a que apresentou maior frequência também foi Avaré.

4.5.3. EFEITO DE REGIÕES NA INCIDENCIA DE Aspergillus spp.

Os resultados (Tabela 11) demonstraram que houve efeito de locais nas épocas da seca e das águas somente, não ocorrendo na época de inverno. Na seca, houve diferença apenas entre as regiões de Jaboticabal, Tatuí e Avaré com 1,0\%, 20,9\% e 13,9\%, respectivamente. Nas águas, Tatuí e Paraguaçu-Paulista apresentaram maior incidência do fungo, diferindo das demais, com 25,4 e 15,9\%, respectivamente. 
4.5.4. EFEITO DE REgiões NA INCIDENCIA DE Cladosporium sp.

Houve efeito de locais nas épocas da seca e das águas, não ocorrendo na época de inverno. Na seca, a pior região foi Fernandópolis, não diferindo de Araçatuba e as melhores foram Jaboticabal, Avaré e Tatuí, não diferindo das demais.Nas águas, a pior foi Paraguaçu-Paulista, seguida de Aguai e as melhores foram Itapetininga, Avaré e Tatui (Tá bela 12) .

4.5.5. EFEITO DE REGIÖES NA INCIDENCIA DE Fusarium spp.

Houve efeito de locais nas épocas da seca e das águas, não ocorrendo no inverno. Na seca, somente Avaré diferiu das demais, com exceção de Fernandópolis, sendo as regiões com maiores frequências de espécies de Fusarium. Nas águas, Avaré com a maior frequência somente diferiu de Aguaí. Embora as médias tenham aparentemente uma grande variação entre si, a ausência de significância deve-se possivelmente ao número variável de repetições das regiões amostradas (Tabela 13). 
4,5.6. EFEITO de REgiões na incidencia de Penicillium spp.

Houve efeito de locais nas três épocas de pro dução. Na seca houve diferença apenas entre Araçatuba e Tatuí, com a menor e a maior frequência, respectivamente. Nas águas, Avaré apresentou menor incidência e Paraguaçu-Paulista apresentou a maior. No inverno houve diferença apenas en tre Aguai, Ibitinga e Presidente Prudente, com as menores e a maior frequência, respectivamente (Tabela 14).

4.5.7. EFEITO DE REgiões NA INCIDENCIA DE Phomopsis sp.

Houve efeito de locais nas épocas das águas e de inverno, não ocorrendo na seca. Nas äguas, ParaguaçuPaulista apresentou a maior frequência, enquanto no inverno, somente Bauru diferiu de Jaboticabal e Presidente Prudente, com frequência maior e menores, respectivamente (Tabela 15).

4.5.8. EFEITO DE REGIÕES NA INCIDENCIA DE Rhizoctonia solani

Os resultados (Tabela 16) demonstraram que não houve efeito de locais para o fungo, em nenhuma das três épocas estudadas. 


\subsection{EFEITO DE REgIÕes E DE ÉPOCAS NA GERMINACÃO E ENVE- LHECIMENTO ACELERADO DAS SEMENTES DE FEIJOEIRO}

A Tabela 17 demonstra os valores mínimos, mâximos e médios de germinação e envelhecimento acelerado das sementes, além do nümero de amostras com germinação abaixo do padrão $(80,0 \%)$.

A Tabela 18 demonstra que houve efeito de locais nos dois parâmetros avaliados em alguns casos, não ocorrendo efeito na germinação durante a época da seca e no envelhecimento acelerado durante a época das águas. Na seca, Avaré apresentou a menor porcentagem de vigor, não diferindo somente de Fernandópolis. Nas águas, Avaré apresentou a maior porcentagem de germinação, diferindo somente de Itapetininga. No inverno, Presidente Prudente e Bauru apresentaram maiores valores de germinação, diferindo apenas de Aguaỉ e Fernandópolis; quanto ao vigor, Ibitinga com o maior valor, diferiu de Fernandópolis, Aguaí, Pirassununga e Ribeirão Preto.

Os resultados das médias demonstraram que houve tam bém efeito de época de produção na geninação e no vigor das sementes. Não houve diferença estatística nos resultados de germinação nas épocas da seca e de inverno, mas houve em relação a das águas, que apresentou a menor porcentagem $(68,0 \%)$, enquanto o vigor foi diferente para as três épocas, maior no inverno e menor nas águas. 


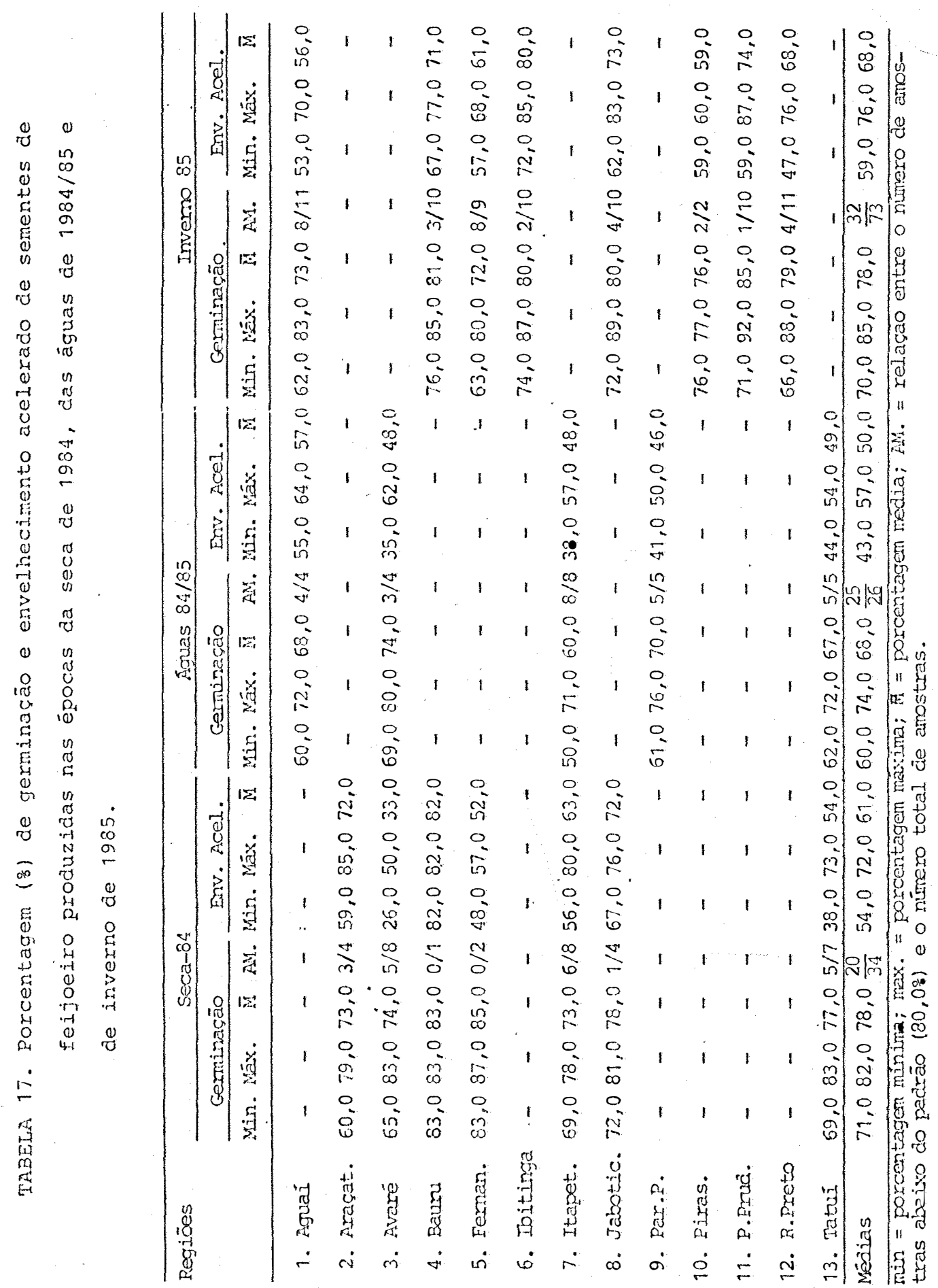


TABELA 18. Efeito de regiões e épocas de produção na porcentagem de germinação e envelhecimento acelerado de sementes de feijoeiro do Estado de São Paulo.

\begin{tabular}{|c|c|c|c|c|c|c|}
\hline \multirow{2}{*}{ Regiões } & \multicolumn{2}{|c|}{ Seca-84 } & \multicolumn{2}{|c|}{ Aguas $84 / 85$} & \multicolumn{2}{|c|}{ Inverno-85 } \\
\hline & Germ. & $\begin{array}{l}\text { Env. } \\
\text { acel. }\end{array}$ & Germ. & $\begin{array}{l}\text { Env } \\
\text { acei. }\end{array}$ & Germ. & $\begin{array}{l}\text { Env. } \\
\text { acei. }\end{array}$ \\
\hline 1. Aguaí & - & - & $68,0 \mathrm{ab}$ & $57,0 \mathrm{a}$ & $73,0 \mathrm{bc}$ & $56,0 \mathrm{~b}$ \\
\hline 2. Araçatuba & $73,0 a *$ & $72,0 a$ & - & - & - & - \\
\hline 3. Avaré & $74,0 \mathrm{a}$ & $33,0 \mathrm{~b}$ & $74,0 \mathrm{a}$ & $48,0 \mathrm{a}$ & - & - \\
\hline 4. Bauru & $83,0 \mathrm{a}$ & $82,0 \mathrm{a}$ & - & - & $81,0 \mathrm{a}$ & $71,0 \mathrm{ab}$ \\
\hline 5. Fernandōp. & $85,0 a$ & $52,0 \mathrm{ab}$ & - & - & $72,0 \quad c$ & $61,0 \mathrm{~b}$ \\
\hline 6. Ibitinga & - & $=$ & - & - & $80,0 \mathrm{ab}$ & $80,0 \mathrm{a}$ \\
\hline 7. Itapet. & $73,0 a$ & $63,0 a$ & $60,0 \mathrm{~b}$ & $48,0 \mathrm{a}$ & - & - \\
\hline 8. Jabotic. & $78,0 a$ & $72,0 \mathrm{a}$ & - & - & $80,0 a b$ & $73,0 \mathrm{ab}$ \\
\hline 9. P.Paulista & - & - & $70,0 \mathrm{ab}$ & $46,0 \mathrm{a}$ & - & - \\
\hline 10. Pirassun. & - & - & - & - & $76,0 \mathrm{abc}$ & $59,0 \quad b$ \\
\hline 11. Pres.Prud. & - & - & - & - & $85,0 a$ & $74,0 \mathrm{ab}$ \\
\hline 12. Rib.Preto & - & - & - & - & $79,0 \mathrm{abc}$ & $68,0 \mathrm{~b}$ \\
\hline 13. Tatui & $77,0 \mathrm{a}$ & $54,0 a$ & $67,0 \mathrm{ab}$ & $49,0 \mathrm{a}$ & - & - \\
\hline Médias** & $77,5 \mathrm{~A}$ & $61,0 \mathrm{~b}$ & $68,0 \mathrm{~B}$ & $50,0 \mathrm{c}$ & $78.0 \mathrm{~A}$ & $68,0 a$ \\
\hline
\end{tabular}

* Médias seguidas pela mesma letra, na vertical, não diferi ram entre si pelo teste de Tukey, ao nivel de $5 \%$ de proba bilidade.

* Médias seguidas pela mesma letra maiúscula ou pela mesma letra minúscula, na horizontal, indicaram que não houve diferença pelo teste de Tukey, ao nivel de 5\% de probabilidade, respectivamente para germinaça e envelhecimento acelerado. 
A Figura 6 ilustra o efeito de época de produ ção na germinação e envelhecimento acelerado das sementes.

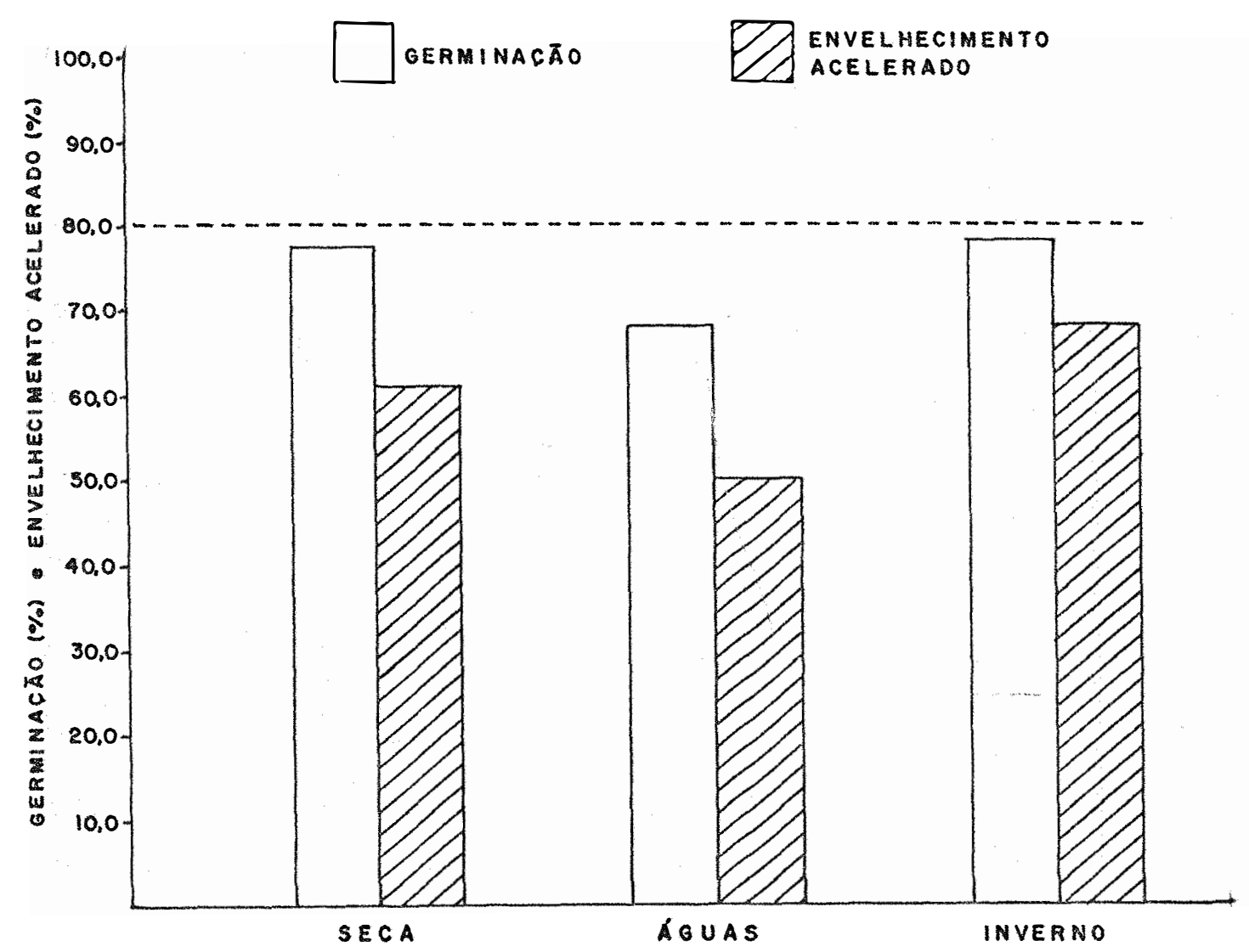

FIGURA 6. Valores médios de germinação e envelhecimento acelerado de sementes de feijoeiro do Estado de São Paulo, produzidas na safra da seca de 1984, das águas de 1984/85 e de inverno de 1985 . 


\subsection{CORRELAÇ̃̃O ENTRE SANIDADE, GERMinAÇ̃̃O E ENVELHECI-} MENTO ACELERADO DAS SEMENTES DE FEIJOEIRO

Os resultados da correlação de sanidade e fisiologia das sementes não se mostraram significativos ao nível de 5\% de probabilidade, segundo o teste $t$, para a maioria dos casos estudados. Somente houve significância entre Alternaria spp. e germinação, e entre Fusarium spp. e vigor das sementes, com valores de $r=-0,68$ e $r=-0,65$, respecti vamente.

A correlação entre a germinação e o envelheci mento acelerado foi significativa ao nivel de 5\% de probabilidade, com valor $r=0,71$, e a equação da reta $y=1,56 \mathrm{x}-$ 55,74 , onde $x$ representa os valores de germinação, e $y$ os valores de envelhecimento acelerado. 


\section{DISCUSSÃO}

\subsection{FUNGOS ASSOCIADOS ÀS SEMENTES DE FEIJOEIRO}

Os 32 fungos detectados nas sementes de feijoeiro no Estado de São Paulo (Item 4.1.) diferiram de uma amostra para outra, em frequência, enquanto que a variabilidade de gêneros e espécies foi basicamente a mesma. Os fungos mais comuns foram os saprófitas ou fungos de armazenamen to: Aspergillus spp., Cladosporium sp. e Penicillium spp., além de Alternaria spp., Alternaria tenuis, Fusarium equiseti, F. moniliforme, F. oxysporum, F. semitectum, Fusarium spp., Phomopsis sp. e Rhizoctonia solani. As espécies mais frequentes de Fusarium foram: F. equiseti e F. semitectum; $F$. solani não foi detectado neste trabalho.

Poucas espécies de fungoś diferiram daqueles re lacionadas por RICHARDSON (1979 e 1981). Entre elas estão 
A. teniis, Botryodiplodia theobromae e Colletotrichum dematium, porém, já relatadas por LASCA (1978), MENEZES et alii (1981) e OLIVEIRA (1984). B. theobromal foi observado, neste trabalho, incidindo em algumas sementes mortas e plântulas anormais durante a avaliação dos testes de germinação e vigor, apresentando lesões escuras nos cotilédones e hipocótilo, sintomas semelhantes àqueles causados por M. phaseolina. RICHARDSON (1979 e 1981) não mencionou B. theobromae nas sementes, LASCA (1978) e OLIVEIRA (1984) não relataram sua importância e MENEZES et alii (1981) citaram como sendo um dos fungos causadores de podridões.

Pelos levantamentos já realizados por LASCA (1978) e ITO et alii (1981) em São Paulo, SANTOS et alii (1986), TANAKA \& DESLANDES (1978), MELO (1980), MACHADO \& PITTIS (1983) em Minas Gerais, MENEZES et alii (1981) no Paraná, OLI VEIRA (1984) na Bahia, SANTOS et alli (1986) no Espírito Santo, e o do presente estudo em São Paulo, observou-se que os fungos associados às sementes de feijão basicamente naõ diferem de uma região para outra.

De uma maneira geral, pode-se considerar, que a qualidade sanitária de sementes de feijoeiro produzidas no Estado de São Paulo foi bastante favorável, com reduzida incidência de fungos, principalmente aqueles de maior importân cia econômica, como Macrophomina phaseolina e Colletotrichum lindemuthianum. Embora em baixa frequência $(0,5$ a 1,0\%), $C$. lindemuthianum ocorreu em sementes genēticas, certificadas-A 
e certificadas-B, em $4,5 \%$ do total de amostras avaliadas das cultivares Carioca e Carioca-80 (Tabela 4).

VIEIRA (1983) relatou, no entanto, que Carioca-80, resultante do cruzamento de Carioca x Cornell 49-242, possui 0 gene dominante Are, que governa resistência às raças alfa, beta, gama, delta, epsilon e lambda, mas suscetível à raça kapa do patógeno. DUDIENAS \& POMPEU (1985), através de inoculações em 12 variedades diferenciadoras deteminaram a raça sigma, ocorrendo nas regiões de Itaberá, Capão Bonito e Pạ riquera-Açu, do Estado de São Paulo e mostraram a ocorrência do grupo alfa em Itararé e Votuporanga. MENEZES et alii (1982) verificaram a existência da raça kapa no Paraná. Assim, há possibilidade de que o patógeno ocorrendo em sementes do Estado de são Paulo, pertença à raça sigma ou kapa. Caso isso ocor ra, cuidados especiais deverão ser tomados durante a multiplicação do material.

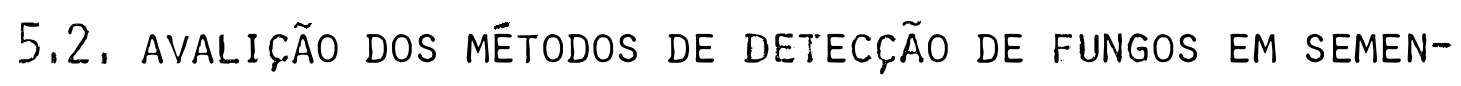 TES DE FEIJOEIRO}

Os principais métodos já utilizados em testes de sanidade de sementes de feijoeiro são o papel de filtro comum, papel de filtro com congelamento, plaqueamento em āgar, rolo de papel e variações destes utilizando-se assepsia das sementes (DHINGRA, 1978; LASCA, 1978; NEERGAARD, 1979a; LEACH, 1979; ANSELME, 1979; ANSELME \& CHAMPION, 1981; 
OLIVEIRA, 1984). Neste trabalho foram considerados dois mëtodos que têm boas possibilidades de serem utilizados em laboratório de rotina, principalmente pelo baixo custo e facilidade de instalação.

Os testes de sanidade, método de papel de fil tro comum e papel de filtro com congelamento não diferiram essencialmente quanto à praticidade de instalação. Contudo, a avaliação do segundo método é mais fácil devido a inibïção da germinação das sementes, alēm de recuperar maior porcentagem de fungos, excetuando-se Penicillium spp. Mesmo assim, a recuperação desse fungo no segundo método foi boa (Tạ bela 2).

Os maiores resultados no método de papel de filtro com congelamento possivelmente devem-se ao choque tér mico das sementes quando submetidas à temperatura de $-18^{\circ} \mathrm{C}$ por 24 horas, o que promove inibição da germinação. A menor incidência de Penicillium spp. pode ser explicada pela maior competição dos demais microrganismos favorecidos pelo "stress" das sementes. Foi comum nesse método a ocorrência de bactérias, aparentemente saprófitas, que poderiam ser um dos fatores concorrentes à diminuição desse fungo.

IIMONARD (1968), ao relatar a utilização do método de papel de filtro com congelamento, não considerou a germinação das sementes essencial, e considerou vigor do hos 
pedeiro um fator influente nos resultados dos testes de sani dade. Dessa maneira, seria interessante se o vigor e assim, a resistência à infecção, fosse reduzida, para que o desenvolvimento de muitos patógenos no hospedeiro fosse estimulada, além dos resultados não variarem devido às diferenças de vigor entre as sementes. Isso explica a porcentagem máxima de fungos encontrada após o vigor ser reduzido a zero, como é feita no teste com congelamento, contanto que nenhum outro fator como bactérias ou fungos antagônicos interferissem.

Para o autor, os resultados obtidos nesse método são semelhantes àqueles do plaqueamento em ágar. Talvez a diferença entre o plaqueamento em ágar e o papel de filtro comum, sem congelamento, deva-se à resistência do hos pedeiro. No plaqueamento em ágar a resistência do hospedeiro não é representativa; assim sementes congeladas, especialmente se não germinarem, são comparáveis ao meio ágar, que é um material nutritivo, pois, quando a viabilidade das sementes é diminuída, elas tendem a exsudar mais substâncias nutrí tivas, açūcares e aminoācidos.

Os baixos valores apresentados na Tabela 2, devem-se ao fato de muitas amostras apresentarem-se livres do fungo, diminuindo consideravelmente a média de incidência, e não devido à falta de sensibilidade dos métodos.

A rápida germinação das sementes no teste de 
papel de filtro comum dificultou, de certa maneira, a avalia ção dos fungos sob microscópio estereoscópico, após 8 dias de incubação. Além disso, frequentemente, as tampas das placas de plástico levantavam-se durante a incubação das sementes na câmara, pelo vigor das plântulas já desenvolvidas nesse período, o que proporcionou maior contaminação ambiente, constatada pela presença de Rhizopus sp. e'Neurospora sp., mascarando o resultado de determinadas repetições, além do secamento do papel de filtro das placas abertas. Tal secamento pode explicar também os menores resultados de incidência da maioria dos fungos nesse método.

5.3. CORRELAÇÃO ENTRE MÉTOdOS DE DETECÇÃO DE FUngOS EM SEMENTES DE FEIJOEIRO

Pelos resultados obtidos através do teste $t$, os valores do coeficiente de correlação indicaram significân cia positiva entre os dois métodos de detecção utilizados, com exceção a F. moliforme e F. oxysporum. A ausência de correlação para essas espécies, deve-se, possivelmente, ao elevado número de amostras isentas dos dois fungos considera dos.

A outra análise de regressão linear, apesar de mostrar resultados proporcionalmente semelhantes à prime ra, foi significativa somente para Cladosporium sp., com o 
erro padrão normalizado (N.S.E.) igual a 0,30. para maio ria dos fungos avaliados, os valores de N.S.E. estiveram acima de $30 \%$, provavelmente devido ao grande número de amostras com valores nulos de incidência do microrganismo, de tal modo que muitos pontos distanciaram-se da reta; também os resultados não sofreram transformação como no primeiro teste. Este foi menos rigoroso que o segundo, indicando maior correlação entre os resultados pelo número elevado de repetições, 133 por coluna, representadas pelas amostras avaliadas em cada método de detecção.

Pelo teste $t$, pode-se sugerir a substituição do método de papel de filtro com congelamento, quando na ausência de um ambiente adequado com temperatura próxima à $-20^{\circ} \mathrm{C}$, pelo método de papel de filtro comum, através das equações das retas, ou vice-versa, dependendo das circunstân cias (Tabela 6).

5.4. DISTRIBUIÇÃO GEOGRÄFICA DE FUNGOS EM SEMENTES DE FEI JOE IRO

Embora as épocas consideradas para o estudo da distribuição geográfica dos fungos associados às sementes de feijoeiro no Estado de São Paulo, foram somente de 1984 e 1985, e o número de municípios pertencentes às regiões ordenadas possa ser pouco representativo, é válido fazê-lo como 
primeira tentativa. A maioria dos fungos estudados apresentaram uma distribuição totalmente aleatória, com exceção de A. tenuis, Cladosporium sp. e $R$. solani que tiveram uma certa tendência em se concentrar em determinadas partes do Estado, respectivamente: centro-sul, oeste e nordeste, e centro.

Conforme era de se esperar, a significância somente foi verificada para determinados fungos de campo, en quanto os fungos de armazenamento, como Aspergillus spp. e Penicillium spp., tiveram distribuição aleatória, pois sua Erequência depende pouco das condições ambientes do campo de cada região produtora. A diferença entre regiões na incidên cia de fungos em sementes foi considerada por alguns autores como sendo devido à diversidade climática. MENEZES et alii (1981) encontraram baixa frequêrncia de amostras de sementes de feijoeiro da cultivar Rio Tibagi infectadas com M. phaseolina, resultante do local de cultivo, sul do Estado do Pa raná, onde as condições climáticas não são favoráveis ao desenvolvimento da doença. LASCA (1978), verificou menor incidência de fungos em sementes de feijoeiro produzidas em São Paulo que no Paraná, possivelmente devido às condições climá ticas diferentes.

ELLIS \& GÁLVEZ (1980) indicaram como região favorável à produção de sementes de feijoeiro livres de pató genos, quando a precipitação ocorrer abaixo de $300 \mathrm{~mm}$, a umi 
dade relativa diāria inferior a 60\%, temperaturas diārias en tre 25 e $35^{\circ} \mathrm{C}$, irrigaçäo por infiltração, e região não utili zada para plantio comercial.

Yerkes \& Crispin, citados por RAVA et alii (1981) constataram a não transmissão de C. lindemuthianum quando a semente infectada foi cultivada em regiões āridas do México durante o inverno, utilizando irrigação por infiltração.

5.5. EFEITO DO GEINÓTIPO NA INCIDÊNCIA DE FUNGOS, GERMINAĊ̃̃O E ENVELHECIMENTO ACELERADO DAS SEMENTES DE FEIJOE IRO

o efeito do genótipo na qualidade de sementes é conhecido em diversas culturas. MENTEN et alii avaliaram 25 cultivares de feijoeiro, e verificaram diferenças significativas na incidência de patógenos associados às sementes entre as cultivares. Trabalhos semelhantes foram feitos por LASCA et alii (1983) em trigo, NUNES Junior (1984) em soja, NAKAMURA e SADER (1985) em arroz e BUENO (1986) em algodão.

No presente trabalho foi verificado que a cultivar Ca rioca-80 apresentou menor incidência de fungos, como A. tenuis, As pergillus spp., Fusarium spp. e R. solani que a cultivar Ca- 
rioca (Tabela 7). Além da melhor qualidade sanitária das sementes da Carioca-80, esta apresentou também, qualidade fisiológica superior, pelo maior vigor das sementes, numa variação de 16,0 pontos percentuais, em relação à Carioca (Tabela 8).

Segundo ASMUS \& DHINGRA (1985), as cultivares podem diferir na sua reação à patógenos foliares e radiculares, pela diferença de suscetibilidade a patógenos de sementes, independentes das condições climáticas e regiões produtor s. Os autores realizaram um estudo para desenvolver um sistema de classificação de cultivares de feijoeiro conforme sua suscetibilidade à infeção de sementes, obtendo resultados onde as cultivares Rico 23 e Carioca tiveram 18 de semen tes infectadas com C. Lindemuthianum e a cultivar Bolinha te ve $15 \%$ de sementes infectadas. Foi detectado diferenças de suscetibilidade à infecção de sementes por A. tenuis, Cercos pora canescens, colletotrichum dematium var. truncata, F. semitectum, Isariopsis griseol a e Phomopsis sp.

5.6. SELEÇÃO DE REgIÕEs E ÉPOCAS dE PRODUÇÃO DE SEMENTES de feijoeiro no estado de São Paulo

Dentro das limitações do trabalho, o pequeno nümero de amostras e municípios representando determinadas regiões, e a falta de controle de informações de alguns da- 
dos importantes, como época exata de colheita, a qual é sabi do exercer efeito na qualidade das sementes, podem ser consi deradas as mais importantes. Quanto às amostragens, elas seguiram uma uniformidade, uma vez que as amostras representaram lotes de sementes. Dessa maneira, o fator umidade das sementes não deve ter influenciado, uma vez que o padrão no sistema de certificação prescreve um teor máximo de 13,08 pa ra sementes básicas e certificadas (INTERNATIONAL RULES FOR SEED TESTING, 1976; CATI, 1984). Embora possa existir diferença entre classes de certificação, as sementes não foram avaliadas segundo essa característica, pois diminuiria ainda mais a representatividade de cada região e época.

As sementes de Eeijoeiro produzidas no Estado de São Paulo, pelos resultados obtidos, pode ser considerada de boa qualidade sanitária, onde a frequência dos fungos detectados foi baixa para a grande maioria das amostras analisadas. Quanto à qualidade fisiológica, parte considerável das amostras encontrou-se abaixo dos padrões de germinação $(80,0 \%)$, principalmente na época das águas. No entanto, ape sar da evidência das condições climáticas terem influenciado na redução da germinação e envelhecimento precoce, as con dições adversas de transporte da região produtora ao local onde as sementes foram analizadas devem ser consideradas, con tribuindo nessa redução, e consequentemente, elevando o núme mero de amostras abaixo do padrão (Tabela 17). 
Não obstante as variāveis serem muitas, os resultados estatísticos revelaram que as sementes produzidas na época de inverno possuem melhor qualidade fisiológica que da seca, e esta, superior a das águas. As regiöes seleciona das dentro de cada época, de acordo com os valores de germinação e envelhecimento acelerado poderiam ser: Presidente Prudente, Itibinga e Bauru no inverno, Bauru, Jaboticabal, Araçatuba, Ipatetininga e Tatuí na seca e Avaré nas āguas (Tabela 18). Durante a safra de inverno, a baixa precipitaçäo em relação à safra da seca, e principalmente à das águas (Tabela 1) deve ser responsável pelos maiores valores de ger minação e envelhecimento acelerado, além da maior incidência de fungos, exceto Cladosporium (Tabela 12).

A baixa incidēncia de fungos importantes economicamente nas sementes de feijoeiro, no Estado de são Paulo, possivelmente devido ao controle rigoroso dos padrões de campo, em que os cuidados são especiais em todas etapas de cultivo, não justificaria a seleção de locais mais adequa dos para produção de sementes sadias. Entretanto, é importante atentar para a ocorrência de colletotrichum lindemuthianum em $4,5 \%$ das amostras, envolvendo sementes genéticas e certificadas.

Segundo ISSA et alii (1964), enquanto não se obtiver cultivares resistentes, o que é difícil pela comple- 
xidade do problema porque 0 patógeno da antracnose possui muitas raças, existem várias espécies de bactērias, a melhor forma de controle dessas doenças é o emprego de sementes seguramente sadias, complementado pela rotação de cultura. Pa ra isso, deve-se produzir sementes em regiões onde a umidade relativa seja baixa.

As regiões pertencentes à época de inverno poderiam ser consideradas as melhores para produção de sementes sadias e com maior capacidade fisiológica, entre elas: Aguaỉ, Bauru, Fernandópolis, Ibitinga, Jaboticabal, Pirassununga, Presidente prudente e Ribeirão Preto. Nenhuma delas apresentou sementes com $C$. lindemuthianum. Apesar da baixa incidência do patógeno nas sementes das águas e seca, com $4,5 \%$ de amostras infectadas, o pequeno inóculo poderia repre sentar problemas à cultura, sob condições favoráveis, o que poderia até mesmo impossibilitar a certificação dos campos de produção.

Embora seja conveniente produzir sementes de feijoeiro durante a safra de inverno, onde há um acentuado déficit hídrico (ROSTON \& BULISANI, 1983) pode-se recomendar a produção da seca, particularmente nas regiões de Bauru, Jaboticabel, Araçatuba, Itapetininga e Tatui, e caso seja necessário, recomenda-se a região de Avaré para produção na época das águas. Não houve diferença estatística entre ger. 
minaçao nas épocas da seca e de inverno mas houve em relação a das águas, enquanto o vigor variou entre as três ëpocas, ou seja, foi maior no inverno e menor na āgua (Tabela 18).

ISSA et alii (1964) em estudos para produção de sementes de feijoeiro em regiões áridas do nordeste brasí leiro, instalaram os campos às margens do Rio são Francisco na Bahia e Pernambuco, utilizando-se cultivares recomenda das para o Estado de São Paulo. Obtiveram em canteiro orium dos exclusivamente de sementes manchadas, apenas 48 de semen tes doentes para o campo de antracnose e $9 \%$ para o caso de podridão bacteriana. Esperava-se que com um máximo de três cultivos sucessivos, obtivesse sementes de feijoeiro inteiramente livres desses patógenos, como é feito nos Estados Unidos.

Na área do Vale do Paraíba o cultivo do feijoeiro de inverno é indicado apenas nas vārzeas, onde ē menor o risco de geadas devido às condições de umidade, enquanto o cultivo do feijoeiro da seca e das águas, somente nas encostas devido o excesso de temperatura e umidade nas várzeas (ROSTON \& BULISANI, 1983).

Em vista do zoneamento já realizado dos locais mais adequados a cada uma das três épocas produtoras de 
feijão de acordo com os mapas das Figuras 2,3 e 4 e das regiões amostradas no presente trabalho não seguirem exatamente esse zoneamento, como por exemplo Araçatuba e Jaboticabal na seca (item 3.1.1.) e Pirassununga no inverno (ítem 3.1.3.) acredita-se que as sementes poderiam apresentar melhor quali dade se produzidas nas épocas recomendadas.

\subsection{EFEITO DA SANIDADE NA GERMINACAO E ENVELHECIMENTO ACE LERADO DAS SEMENTES. DE FEIJOEIRO}

Observou-se para maioria dos fungos estudados, ausência de correlação entre aspectos sanitário e fisiológico das sementes. A ausência de efeito da sanidade so bre a germinaçãoe o envelhecicmento acelerado das sementes deve-se, possivelmente, pela baixa incidência dos microrganis mos nas sementes, ou em alguns casos, como Clodosporium sp. em que a incidência foi relativamente elevada, atribui-se à propria característica saprofítica em não afetar a fisiologia das sementes (não aparecem plântulas anormais e nem se mentes-mortas). O potencial de inóculo pode ser considerado um fator importante para o estabelecimento de infecção ou reprodução de esporos no hospedeiro, e portanto, a quantidade inicial de inóculo poderia ter sido insuficiente para afetar a germinação e o vigor das sementes, nas condições em que se estabele ceram as avaliações.

Além desses aspectos, outros fatores podem es 
tar interferindo nos resultados e mesmo mascarando o efeito dos fungos sobre as sementes. Dentre esses, encontram-se efeito de época de semeadura e colheita, efeito de locais de produção, fertilidade do solo, cultivares (NEERGAARD, 1979a; MENEZES et alii, 1981; NUNES Jr., 1984; BUENO, 1986). Ainda quando se isola o efeito de um determinado fungo pode-se obter resultados diferentes daqueles que ocorrem com a associa ção de vários fungos e bactérias nas sementes, pela relação de antagonismo ou simbiose entre eles.

Embora o teste estatístico não tenha revelado significância para fungos como Penicillium sp., Aspergillus spp. e Rhizoctonia solani, nitidamente observou-se o efeito negativo deles na germinação e/ou vigor das sementes, durante a realização dos testes de germinação em rolo de papel toalha e do envelhecimento acelerado. Observou-se também a presença de Macrophomina phaseolina e Botryodiplodia theobro mae, durante esses testes, em sementes mortas e plântulas anormais, com os cotilédones, muitas vezes, inteiramente escu recidos.

BUENO (1986) observou correlação significativa entre germinação de sementes de algodoeiro e incidência de A. tenuis, nuis, B. theobromae, C. gossypii e F. moniliforme. LASCA et alii (1978) observou que Helminthosporium sativum em sementes de trigo diminuiu sua germinação e emergência. ELLIS et alii (1976) determianram o efeito negativo na germinação de sementes de feijoeiro pelos fungos 
F. semitectum, Phomopsis $\mathrm{sp}, M$. phaseolina e R. solani. No presente trabalho somente foi verificado efeito negativo de Alternaria spp. na germinação e de Fusarium spp. no envelhecimento acelerado das sementes.

5.8. CORRELAÇ̃̃o ENTRE GERMinAç̃o E VIGOR DAS SEMENTES DE FEIJOEIRO

Os resultados da análise de regressão indicaram a possibilidade de substituição de um teste pelo outro, além de fornecer dados para, na ausência de resultados de um deles, obter-se os resultados do outro. Segundo CARVALHO NAKAGAWA (1983), a capacidade de germinação de um lote de se mentes é determinada pela proporção das que podem produzir plântulas normais, em condições favoráveis. A falta de uma estreita relação entre a germinação obtida no laboratório e a emergência no campo, foi responsável pelo desenvolvimento do conceito de vigor. Da mesma forma, este conceito torna- se importante para se selecionar os lotes que apresentam ger minação semelhante, para fins de armazenamento, porque eles podem apresentar diferentes capacidades de armazenagem. 


\section{CONCLUSÕES}

Os resultados obtidos no presente trabalho permitiram concluir que:

- As sementes melhoradas de feijoeiro produzidas no Estado de são Paulo durante as épocás da seca de 1984, das águas de 1984/85 e de inverno de 1985, apresentaram baixa incidência de fungos.

- A êpoca mais propicia para produção de sementes de feijoei. ro de boa qualidade no Estado de São Paulo foi a de inverno, seguida pela da seca; a época das águas não é recomendada, particularmente pela baixa germinação e vigor das se mentes, além de apresentarem mais fungos.

- As regiões mais favoráveis para produção de sementes de boa qualidade na safra de inverno, da seca e das águas, fo ram respectivamente: Bauru, Ibitinga, Jaboticabal e Presidente Prudente; Bauru, Jaboticabal, Araçatuba, Itapetinin- 
ga e Tatuí; Avaré.

- Colletotrichum lindemuthianum não ocorreu em sementes de feijoeiro produzidas no inverno.

- Sementes de feijoeiro da cultivar Carioca-80 apresentaram melhor qualidade que a cultivar Carioca.

- A germinação de sementes de feijoeiro foi afetada pela incidência de Alternaria spp. e o envelhecimento acelerado foi afetado pela incidência de Fusarium spp.

- Houve uma correlação positiva entre germinação e envelhecí mento acelerado das sementes.

- O método de papel de filtro com congelamento para detecção de fungos foi mais adequado que o método de papel de filtro comum; houve correlação positiva entre os dois métodos.

- A maior parte dos fungos associados às sementes de feijoeiro apresentaram uma distribuição aleatória no Estado de são Paulo, com exceção de Alternaria tenuis, cladosporium sp. e Rhizoctonia solani que se concentraram, respectivamente, no centro-sul, oeste e nordeste, e centro. 


\section{REFERÊNCIAS BIBLIOGRÁFICAS}

ABRASEM. Anuário. Brasillia, janeiro, 1986.

ANSELME, C. Seed pathology problems and progress. In: THE FIRST LATIN AMERICAN WORKSHOP ON SEED PATHOLOGY, LOndrina, 1977. Proceedings. Londrina, IAPAR, 1979. p. 59-66.

ANSELME, C. \& CHAMPION, R. Bean Anthracnose. ISTA handbook on seed health testing. La Minière, França, 45: 1-4, 1981.

APPLE II. Business Graphics. Manipulating the data. California, 1982. cap. 8:130-161.

ASMUS, G.L. \& DHINGRA, O.D. The use of a seed infection index for comparing the susceptibility of bean cultivars to internally seedborne pathogens. Seed Science and Technology, 13(1): 53-58, 1985. 
ATHAYDE, A.O. \& PACOVA, B.E.V. Doenças e técnicas de produção de sementes sadias de feijão (Phaseolus vulgaris L.) no Estado do Espirito Santo. Circular récnica, Vitória, EMCAPA, 1985. 49 p. (10).

AZEVEDO;, J.T. \& LAUDARES Filho, L.A. Produção de sementes de feijão de alta qualidade. Informe Agropecuärio, Belo Horizonte, $8(90): 34-35,1982$

BARNETT, H.L. \& HUNTER, B:B. Ilzustrated genera of imperfect fungi. 3 ed. Minneapolis, Burgess Publishing, 1972. 241 $\mathrm{p}$.

BERGAMIN Filho, A. Importância epidemiológica de patógenos associados a sementes. In: SIMPÓSIO BRASILEIRO DE PATOLO GIA DE SEMENTES, 1., Piracicaba, 1984. Anais. Piracica ba, ABRATES, 1984. p. 54 .

BOLKAN, H.A. Las pudriciones radicales. In: SCHWARTZ, H.F. \& GÁLVEZ, G.E., ed. Problemas de producción del frijol; enfermedades, insectos, limitaciones edäficas y climäticas de Phaseolus vulgaris. Cali, Colōmbia, CIAT, 1980. cap. 5, p. 65-99.

BOLKAN, H.A.; SILVA, A.R.; CUPERTINO, F.P. Fungi associated with soybean and bean seeds and their control in Central Brazil. Plant. Disease Reporter, Washington, 60: 545-548, 1976 . 
BOLKAN, H.A.; WENHAM, H.T.; MILNE, K.S. Effect of soil temperature on severity of Rhizoctonia solani infection on potato shoots. Plant Disease Reporter, Washington, 58: $646-649,1974$.

Bоотн, C. The genus Fusarium. Kew, Surrey, England. Commonwealth Mycological Institute. 1971. 237 p.

BRASIL. Ministério da Agricultura. Secretaria Nacional de Defesa Agropecuária. Laboratório Nacional de Referência Vegetal. Regras para anälise de sementes. Brasilia, 1976. $188 \mathrm{p}$.

BUENo, J.T. Influência de genótipo e local de produção na incidência de fungos em sementes de algodoeiro (Gossypium hirsutum L.) no Estado do Paraná. Piracicaba, 1986. 99 p. (Mestrado - Escola Superior de Agricultura "Luiz de Queiroz" da Universidade de São Paulo).

CAFATI, C.R. \& SAETTLER, A.W. Transmission of Xanthomonas phaseoli in seed of resistant and susceptible Phaseolus genotypes. Phytopathology, New York, 70(7): 638-640, 1980 .

CARDOSO, J.E.; OLIVEIRA, E.B.; MESQUITA, J.E.L. Efeito da mela do feijoeiro na qualidade da semente. Comunicado Técnico, Rio Branco, EMBRAPA, 1980. 3 p. (18). 
CARVALHO, N.M. \& NAKAGAWA, J. Sementes; ciência, tecnologia e producão. 2 ed. Campinas, Fundação Cargill, 1983. 429 p.

CATI. Padrões de Sementes. Governo do Estado de São Paulo, Secretaria da Agricultura e Abastecimento. Campinas, 1984. 34 p.

COSTA, A.S., coord. Investigações sobre molēstias de feijoeiro no Brasil. In: SIMPÓSIO BRASILEIRO DE FEIJÃO, 1., Campinas, 1971. Anais. Campinas, 1972. 2 v. 649 p.

CUPERTINO, F.P.; LIN, M.T.; KITAJIMA, E.W.; COSTA, C.L.

Occurrence of southen bean mosaic virus in Central Brazil. Plant Disease, Washington, E6 (8): 742-743, 1982.

DHINGRA, O.D. Internally seedborne Fusarium semitectum and Phomopsis sp. affecting dry and snap bean seed quality. Plant Disease Reporter, Washington, 62(6): 509-512, 1978.

DHINGRA, O.D. Prejuizos causadas por microrganismos durante - armazenamento de sementes. In: SIMPÓSIO BRASILEIRO DE PATOLOGIA DE SEMENTES, 1., Piracicaba, 1984. Anais. Piracicaba, ABRATES, 1984. p. 67-71.

DHINGRA, O.D.; FERNANDEZ, C.M.A.; KUSHALAPPA, A.C. Lack of relationship between field incidence of bean anthracnose and production of seeds, transmitting colletotrichum lindemuthianum. Fitopatologia Brasizeira, Brasilia, 11(1): $95-101,1986$. 
DHINGRA, O.D. \& MUCHOVEJ, J.J. Pod rot, seed rot, and root rot of snap bean and dry bean caused by Fusarium semitectum. Plant Disease Reporter, Washington, 63(1): 84-87, 1979 .

DHINGRA, O.D.; MUCHOVEJ, J.J.; FILHO, J.C. Tratamento de Se mentes; controle de patögenos. Viçosa, 1980. $121 \mathrm{p}$.

DONGO, S.L. \& MULLER, L.E. Pathogenecity studies of Fusarium oxysporum f. phaseoli in beans. Turrialba, Costa Ri $\mathrm{ca}, \underline{19}(2): 82-90,1969$.

DUDIENAS, C. \& POMPEU, A.S. Nova raça fisiológica de Colletotrichum lindemuthianum no Estado de São Paulo. In: SEMINARIO SOBRE PRAGAS E DOENÇAS DO FEIJOEIRO, 2., Campinas, 1985. Resumos. Campinas. Instituto Agronômico, 1985. p. 38 .

EDGINGTION, L.C.; MARTIN, R.A.; BRULN, G.C.; PARSONS, I.M. Systemic fungicides a perspective after 10 years. Plant Disease, washington, 64(1): 19-23, 1980.

EIRA, M.T.S. Contribuição do Ministério da Agricultura para a integração Patologia - Tecnologia de Sementes. In: SIM PÓSIO BRASILEIRO DE PATOLOGIA DE SEMENTES, 1., Piracicaba, 1984. Anais. Piracicaba, ABRATES, 1984. p. 2-4.

EKPO, E.J.A. \& SAETTLER, A.W. Distribution pattern of bean common mosaic virus in developing bean seed. Phytopatho Logy, New York, 64: 269-270, 1974. 
ELLIS, M.A. \& GALVEZ, G.E. Patología de la semilla. In: SCHWARTZ, H.F. \& GALVEZ, G.E., ed. Problemas de producción del frijol; enfermedades, insectos, limitaciones edā ficas y climáticas de Phaseolus vulgaris. Cali, Colômbia CIAT, 1980, cap. 16, pg. 301-314.

ELLIS, M.A.; GALLVE, G.E.; SINCLAIR, J.B. Effect of pod contact with soil on fungal infection of dry bean seeds. Plant Disease Reporter, Washington, 60: 957-976, 1976.

ELLIS, M.B. Dematiaceous Hyphomycetes. Kew, Survey, England, Commonwealth Mycological Institute. 1971. 608 p.

ELLIS, M.B. More Dematiaceous Hyphomycetes. Kew, Survey, England, Commonwealth Mycological Institute, 1976. 507 p. GALVEZ, G.E. Virus transmitidos por afidos. In: SCHWARTZ, H.F. \& GALVEZ, G.E. ed. Problemas de producción del frí jör; enfermidades, insectos, limitaciones edáficas y climáticas de Phaseolus vulgaris. Cali, Colômbia, CIAT, 1980. cap. 12, pg. 211-238.

GOMES, J.L.L. \& DHINGRA, O.D. Alternaria alternata - a serious pathogen de white colored snap bean (Phaseolus vulgaris) seeds. Fitopatologia Brasileira, Brasilia, 8 (1): 173-177, 1983 . 
GRAHAM, J.H. \& LUTTRELL, E.S. Species of Leptosphaerulina on forage plants. Phytopathology, New York, 51: 650-693, 1961.

GREGORY, P.J.; GUTHRIE, E.J., BUNCE, M.E. Experiments on splash despersal of fungus spores. Journal General of Microbiology, Cambridge, 20: 328-354, 1959 .

HAGEDORN, D.J. \& WADE, E.K. Bean rust and angular leaf spot in Wisconsin. Plant Disease Reporter, Washington, 58: $330-332,1974$.

INTERNATIONAL RULES FOR SEED TESTING. Seed Science and Technology. Norway, 4 : 51-177, 1976.

ISSA, E.; REGIS, J.N.M.; VIEIRA, M.L.; ARAUJO, J.T.; MIYASAKA, S. Primeiros estudos para produção de sementes sadias de feijão em regiões áridas do nordeste brasileiro • Arquivos do Instituto Biolögico, são Paulo, 31(5): 21-25, 1964.

ITO, M.F.; PARADELA Filho, O.; SOAVE, J.; D'ALMEIDA, L. LO calização de área adequada para produção de semente sadia de feijão no Estado de são Paulo. In: CONGRESSO PAULISTA DE Fitopatologia, 4., Campinas, 1981. Resumos. Campinas, IAC, 1981. p. 18. 
KENNEDY, B.W. The occurrence of Aspergillus spp. on stored seeds. Seed Pathology Problems and Progress. Londrina, IAPAR, 1979. p. 257-261.

KIMATI, H. Doenças do feijoeiro. In: GALLI, F., ed., Manual de fitopatologia. ed. 2. São Paulo, Ceres, 1980. v.2, cap. 19, p. 297-318.

KORE, S.S. \& SOLANKE, R.B. Efficacy of fungicides on mycoflora of French bean (Phaseolus vulgaris L.). Indian Journal of Mycology and Plant Pathology. 12(1): 76-78, 1982 .

KULSHRESTHA, D.O.; MATH R, S.B.; NEERGAARD, P. Identification of seed-borne species of Colletotrichum. Friesia, Copenhague, 11(2): 116-125, 1976.

LASCA, C.C. Estudos sobre a flora fúngica de sementes de feijão (Phaseolus vulgaris L.). O Biolögico, são Paulo, $\underline{44}(6): 125-134,1978$.

LASCA, C.C. Linhas de pesquisa desenvolvidas em patologia de sementes no Brasil. In: SIMPOSIO BRASILEIRO DE PATOLOGIA DE SEMENTES, 1., Piracicaba, 1984. p. 33-36. 
LASCA, C.C.; BARROS, B.C.; VALLARINI, P.J. Levantamento de fungos de sementes de trigo produzidas no Estado de São Paulo e comparação de incidência de manchas foliares com infeç̧ão de sementes por Helminthosporium sativum. In: CONGRESSO PAULISTA DE FITOPATOLOGIA, 6., Araras, 1983, p. 63. LASCA, C.C.; VALLARINI, P.J.; BARROS, B.C. Avaliação de danos ocasionados por Helminthosporium sativum em sementes de trigo (Triticum aestivum L.) com diferentes niveis de infeccão. Eipatologia Brasileira, Brasilia, 9(2):381, 1978.

LEACH, C.M. Seed pathology problems and progress. In: THE FIRST LATIN AMERICAN WORKSHOP ON SEED PATHOLOGY, LOndrina 1977. Proceedings. Londrina, IAPAR, 1979. p. 59-66.

LIMONARD, T. Ecological aspects of seed health testing. Proceedings of the International Seed Testing Association, Netherlands, $33(3): 347-513,1968$.

LUCCA Filho, O.A. Importância da patologia de produção de sementes de alta qualidade. In: SIMPÓSIO BRASILEIRO DE PATOLOGIA DE SEMENTES, 1., Piracicaba, 1984. Anais, Pira cicaba, ABRATES, 1984. p. 60-66.

MACHADO, J.C. \& PITTIS, J.E. Ocorrência de fungos em sementes de feijão (Phaseolus vulgaris L.) no Estado de Minas Gerais - safra 1982/83. In: CONGRESSO BRASILEIRO DE SEMENTES, 3., 1983, p. 92. 
MELO, B. Qualidade das sementes de feijão (Phaseolus vulgaris L.) utilizadas pelos agricultores da região de Paraca tu, Estado de Minas Gerais, Lavras, 1980. 64 p. (Mestra do - Escola Superior de Agricultura Lavras).

MENEZES, J.R.; MOHAN, S.H.; BIANCHINI, A.; SOUZA, G.L. Qualidade sanitária de sementes de feijão (Phaseolus vulgaris L.) no Estado do Paraná. Fitopatologia Brasizeira, Brasilia, ㅁ: 497-508, 1981.

MENEZES, J.R. Estabelecimento de tolerância a patógenos assoaciados a semente. In: SIMPOSIO BRASILEIRO DE PATOLOGIA DE SEMENTES, 1., Piracicaba, 1984. Anais. Piracicaba, ABRATES, 1984. p. 124-125.

MENEZES, J.R.; MOHAN, S.H.; BIANCHINI, A. Identificação de raças fisiológicas de Colletotrichum lindemuthianum no Es tado do Paraná. In: REUNIÃO NACIONAL DE PESQUISA DE FEIJÃO, 1., Goiânia, 1982. Anais. Goiânia, EMBRAPA-CNPAF, 1982. p. 297-299.

MENTEN, J.O.M. Sanidade, germinação e vigor das sementes de feijão (Phaseolus vulgaris). Summa Phytopathologica, Piracicaba, $\underline{4}: 105-110,1978$.

MENTEN, J.O.M.; GIACOMELLI, A.; TULLMAN Neto, A.; ANDO, A. Efeito da mancha de levedura na qualidade de sementes de feijão (Phaseolus vulgaris L.). Fitopatologia Brasileira, Brasilia, $\underline{4}(3): 493-501,1979$. 
MENTEN, J.O.M.; MACHADO Junior, A.G.; MORAES, M.H.D.; TULMAN Neto, A.; ANDO, A. Efeito do genótipo na incidência de microrganismos em sementes de feijão. Summa Phytopatholo gica, Piracicaba, $6(1,2): 34-35,1980$.

NAKAMURA, A.M. \& SADER, R. Efeito da infecção por fungos na germinação e vigor de sementes de arroz. In: CONGRESSO BRASILEIRO DE SEMENTES, 4., Brasilia, 1985. Resumos. Brasilia, ABRATES, 1985. p. 117.

NATH, R.; NEERGAARD, P.; MATHUR, S.B. Identification of Fusarium species on seeds as they occur in blotter test. Proc. Inst. Seed Test. Ass., Copenhague, 35(1): 121-144, 1970

NEERGAARD, P. Seed Pathology, London, Mac Millan Press Ltd. , 1979a, v. 2, 839 p.

NEERGAARD, P. Seed Pathology problems and progress. In: THE FIRST LATIN AMERICAN WORKSHOP ON SEED PATHOLOGY, LONdrina, 1977. Proceedings. Londrina, IAPAR, 1979b. p. 50 .

NUNES Jünior, J. Efeito do genótipo e da época de semeadura na sanidade de sementes de soja (Glycine max L.) no Estado de Goiás. Piracicaba, 1984. 144 p. (Mestrado - Esco la Superior de Agricultura "Luiz de Queiroz" da Universidade de são Paulo) . 
OLIVEIRA, M.Z.A. Fungos associados a sementes de feijão pro cedentes da região nordeste do Estado da Bahia. Pesquisa em Andamento, Salvador, EPABA, 1984. 5 p. (6).

PEREIRA, O.A.P. A patologia de sementes no contexto da indústria brasileira de sementes. In: SIMPOSIO BRASILEIRO DE PATOLOGia dE SEMENTES, 1., Piracicaba, 1984. Anais. Piracicaba, ABRATES, 1984. p. 30-32.

PHATAK, H.C. Seed borne plant viruses - identification and diagnosis in weed health testing. Seed Scince and Technology. Norway, $\underline{2}: 3-155,1974$.

PROGNOSTICO 1984/85, São Paulo, 13: 1984. 229 p.

RAVA, C.A.; VIEIRA, E.H.N.; COSTA, J.G.C.; SILVEIRA, P.M. Obtenção de germoplasma de feijão livre de patógenos trans missiveis pela semente. Revista Brasizeira de Semente, Brasilia, $3(3): 135-146,1981$.

RICHARDSON, M.J. An annotated list of seed-borne diseases. Commonwealth Mycological Institute. Kew Survey, England, 1979. $320 \mathrm{p}$.

RICHARDSON, M.J. Supplement 1 to an annotated list of seecborne diseases. ed. 3. Zurich, Switzerland, ISTA, 1981. $78 \mathrm{p}$. 
ROCHA, H.M. Contribuição do serviço de quarentena como limi tante à disseminação de patógenos por sementes. In: SIMPÓSIO BRASILEIRO DE PATOLOGIA DE SEMENTES, 1., Piracicaba, 1984. Anais. Piracicaba, ABRATES, 1984. p. 55-59.

ROSTON, A.J. \& BULISANI, E.A. Feijão. Instrucão Prätica, Campinas, CATI, 1983. 29 p. (219).

SANTOS, A.F.; ATHAYDE, J.T.; DAN, E.L.; PACOVA, B.E.V. Fungos associados às sementes de feijão (Phaseolus vulgaris L.) no Estado do Espírito Santo. Comunicado Técnico, Ví tória, 1986. 3 p. (43).

SARTORATO, A.; SEIJAS, C.A.R.; YOKOYAMA, M. Principais doenças e pragas do feijoeiro comum no Brasil. Documentos, Goiānia, EMBRAPA-CNPAF, 1983, 51 p. (5) .

SCHUSTER, M.L.; COYNE, D:F.; HOFF, B. Comparative virulence of Xanthomonas phaseoli strains from Uganda, Colombia and Nebraska. Plant Disease Reporter, Washington, 57: 74-75, 1973.

SCHWARTZ, H.F. Diversos patógenos fúngicos. In: SCHWARTZu, H.F. \& GALVEZ, G.E., ed. Problemas de producción del frijol; enfermidades, insectos, limitaciones edáficas y climáticas de Phaseolus vulgaris. Cali, Colômbia, CIAT, 1980, cap. 8, pag. 127-151. 
SCHWARTZ, H.F. \& GALVEZ, G.E. Problemas de producción del frijöl; enfermedade, insectos, limitaciones edáficas y climáticas de Phaseolus vulgaris. Cali, Colômbia, CIAT, 1980,424 p.

SIEGEL, S. Estatistica Não-Paramëtrica (para as ciências do comportamento). Mc Graw-Hill no Brasil Ltda., 1975. 350 p.

SILVA, C.M. Alguns aspectos do armazenamento do feijão. In forme Agropecuário, Belo Horizonte, $\underline{4}(46): 64-68,1978$.

SOAVE, J. Perspectivas e prioridades de pesquisa em patologia de sementes no Brasil. In: SIMPOSIO BRASILEIRO DE PATOLOGIA DE SEMENTES, 1., Piracicaba, 1984. Anais. Piracicaba, ABRATES, 1984. p. 47-53.

TANAKA, M.A.S. \& CORREA, M.V. Efeito do tratamento de semen tes de feijão de diferentes qualidades sanitárias com fun gicidas e antibiótico sobre a emergência e "stand". Fito patologia Brasileira, Brasilia, I(3): 339-347, 1982.

TANAKA, M.A.S. \& DESLANDES, J.A. Principais fungos associados a sementes de feijão (Phaseolus vulgaris L.) em alguns municipios de Minas Gerais. Fitopatologia Brasileira, Brasilia, $\underline{3}(1): 108,1978$.

TANAKA, M.A.S. \& MACHADO, J.C. Patologia de sementes. Informe Agropecuário, Belo Horizonte, 11(122): 40-46, 1985. 
TOLEDO, F.F. \& MARCOS Filho, J. Manual das Sementes - Tecno Zogia de Producão. São Paulo, Ceres, 1977. 224 p.

VIEIRA, C. Doengas e pragas do feijoeiro. Viçosa, Universi dade Federal de Viçosa, 1983. 231 p.

VIEIRA, E.H.N. Pesquisa em semente de feijão no Brasil. Re vista Brasizeira de Sementes, Brasilia, 3(3): 59-65, 1981.

VIEIRA, R.F. \& SARTORATO, A. Recomendações técnicas para produção de sementes de feijão de alta qualidade. CircuZar Técnica, Goiānia, EMBRAPA-CNPAF, 1984. 46 p. (10).

WALDER, V.L.M.S. Qualidade das sementes de feijão (Phaselus vulgaris L.) utilizadas pelos agricultores em 28 muni cípios da zona da mata de Minas Gerais. Viçosa, 1976. 64 p. (Mestrado - Universidade Federal de Viçosa).

WALLEN, V.R. \& GALWAZ, D.A. Effective management of bacterial blight of field beans in Ontario - a $10 \mathrm{yr}$ program. Canadian Journal of Plant Pathology, 1: 42-46, 1979 .

WALLEN, V.R. \& SUTTON, M.D. Xanthomonas phaseoli var. fuscans on field bean in Ontario. Canadian Journal of Botany, 43: 437-446, 1965. 
YOSHII, K. Los añublos común y fosco. In: SCHWARTZ, H.F. \& GALVEZ, G.E., ed. Problemas de producción del frijör; enfermidades, insectos, limitaciones edáficas y climáticas de Phaseolus vulgaris. Cali, Colômbia, CIAT, 1980. cap. 9, pag. 155-171.

ZAMBOLIM, L. \& ChAVES, G.M. Doenças do feijoeiro e seu controle. Informe Agropecuário, Belo Horizonte, $\underline{4}$ (46):5063,1978 .

ZINK, E.; D'ALMEIDA, L.; LAGO, A.A. Observações sobre o com portamento de sementes de feijão sob diferentes condições de armazenamento: Bragantia, Campinas, 35(38):443$-451,1976$.

ZONEAMENTO AGRICOLA DO ESTADO DE SÃO PAULO. Aptidão ecológi ca da cultura do feijão. Campinas, $\underline{2}$ (7): 49-55. 1977. 